\title{
فاعلية برناهمج تدريبي في إثراء المفروشات ببعض أساليب التطريز لتحسين المستوى الاقتصادي للأسر المرية
}

\author{
إعلاد

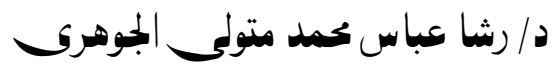 \\ أستاذ النسيج والملابس المساعد بقسم الاقتصاد المنزلي لئي \\ بكلية التربية النوعية -جامعة المنصورة
}

مجلة بحوث التربية النوعية ـ جامعة المنصورة

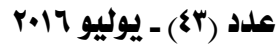




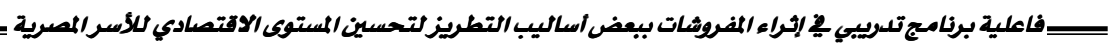




\title{
فاعلية برناهج تدريبي في إثراء المزروشات
}

\section{ببعض أساليب التطريز لتصسين المستوى الاقتصادي للأسر المصرية}

\author{
إعداد \\ م/رشاعباسمحمد متولإلجوهرى
}

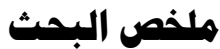

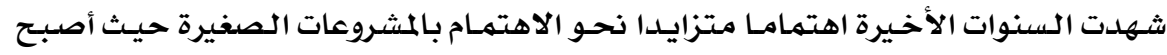

ينظر إليها علـى المستوى المحلـى والعـالمي بأنها العمـود الفقـري لإِنتاج ، وطـرق النجـاة للخـروج مـن

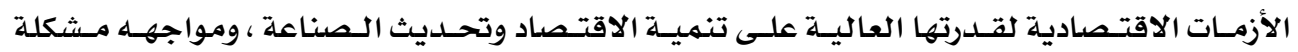

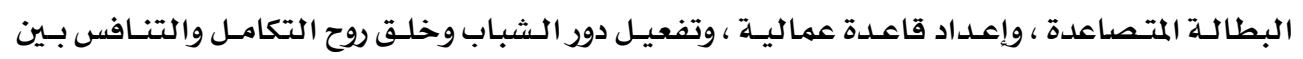
المشروعات وتطوير المستوى المعيشي لكلأفراد.

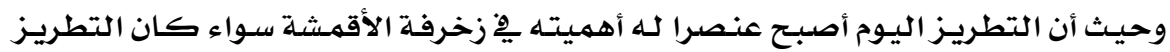

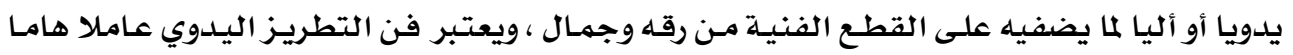
لدعم اقتصاد كثير مـن الدول التي تعتبره مصدرا للدخل القومي لتصدير بعض المنتجات المطرزة إلى

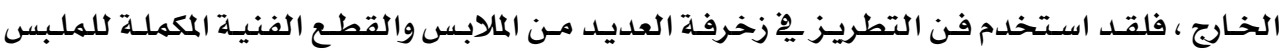

وكذلك استخدم يِ أغطية الرأس والمفروشات وذلك ليزيد المنتج جمالا ويزيد من قيمه الفنيـة. ويظهـر دور التطريـز كأسـلوب لزخرفـه وتـزيـين أقهـشـة المفروثـات بطـرق متعـددة وخـامـات مختلفة كالخيوط بأنواعها مـن حيث " الخامة أو اللون أو نهـر الخيـوط " فعلى ذلك يهكن ان يكون

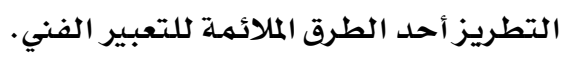
لذا يعد مجال تطـوير المنـاهـ أمـرا حيويـا لكل مـن لـه صـله بعمليـة التربيـة وتعتبر البر امـج التدريبية أحد أشكال تطوير المناهـج فهي تعد بهثابة تنظيم يخطط له مسبقا يخ صورة كلية تتضهن

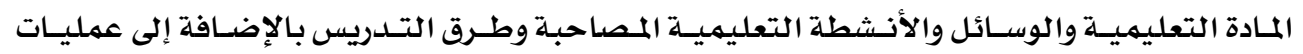
التقويه المستمـرة والتي تؤدى يِ مجموعد إلى بلوغ الأهداف المرجـوة ، ويحتاج ذلك إلى المرور بخبر ات

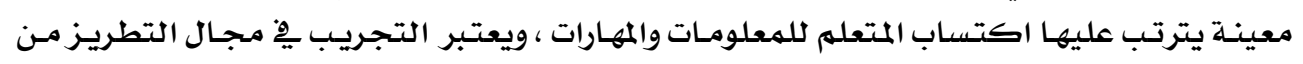
أهم الضرورات التي تحقق أهداف هذا المجال . ومـن هنا كان لابد مـن تصميهم برنامـج تدريبي لطالبـات الفرقة الثالثة اقتصـاد منزلي يهدف إلى تدريبهن على إنتاج مفروشات ذو قيمهـ تصلح كنواه لمشروع صغير، تحديـد مـدى فاعليـة البرنامـاج التـدريبي يِّ إكسـاب الطالبـات المعـارف الـتي تؤهلهن لتتفيـذ مفروشـات تصلح للصناعات الصغيرة ،

"أستاذ النسيج والملابس المساعد بقسم الاقتصاد المنزلي - بكلية التربية النوعية جامعة المنصورة 
تحديد مدىى مساهمة البر نامج التدريبي يِّ إكساب الطالبات المهارات التي تؤهلهن لتنفيـذ مفروشـات

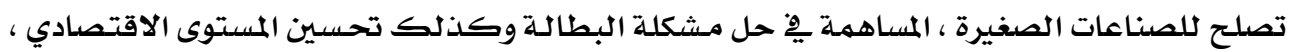

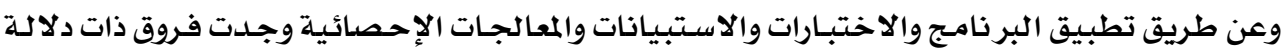

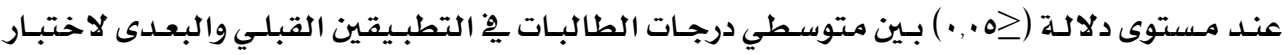

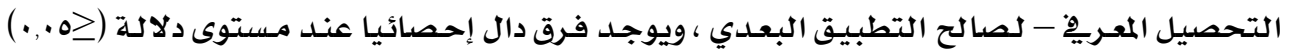

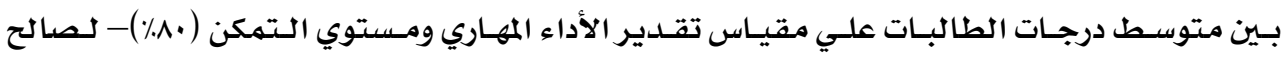

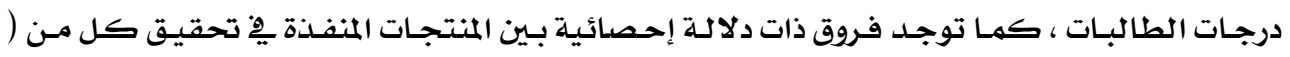

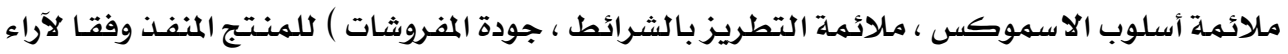

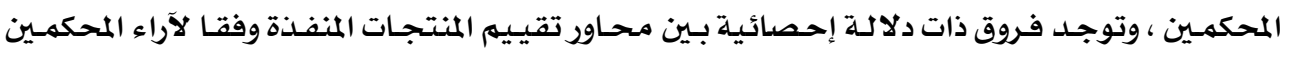

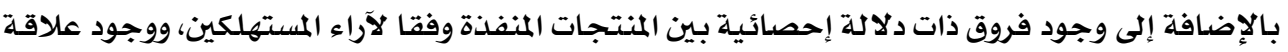

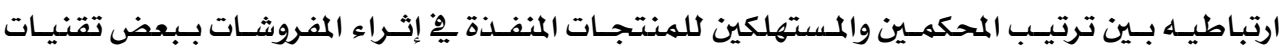

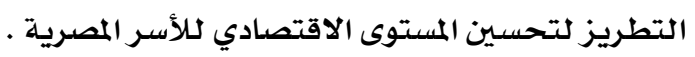

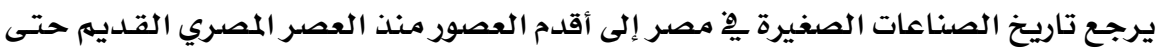

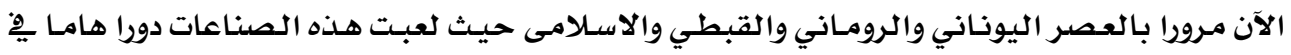

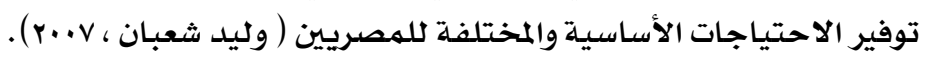

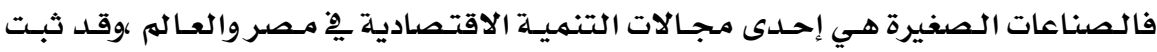

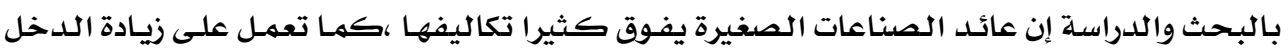

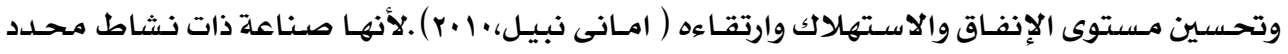

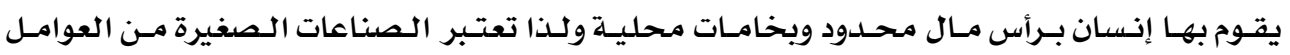

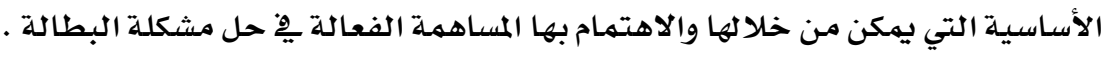

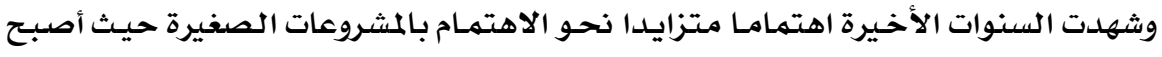

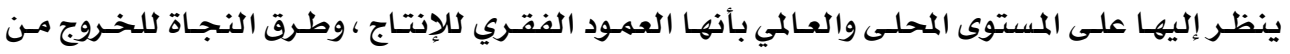

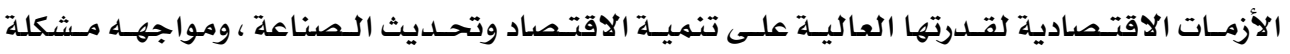

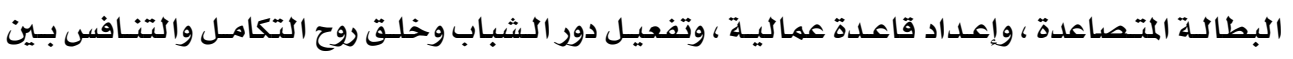

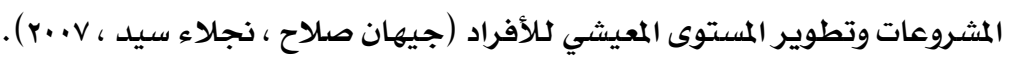

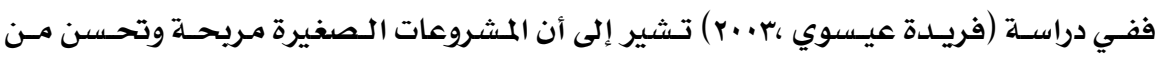

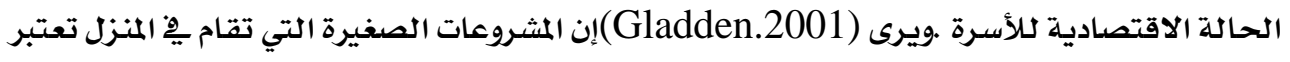

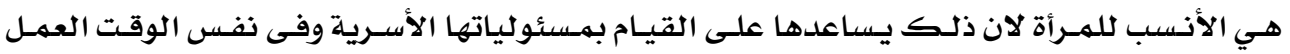

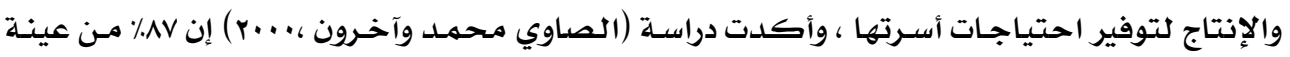

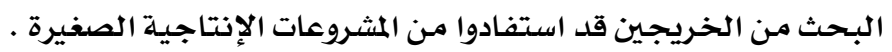




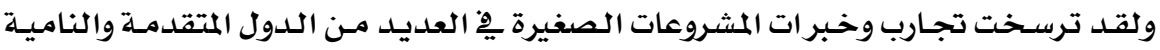

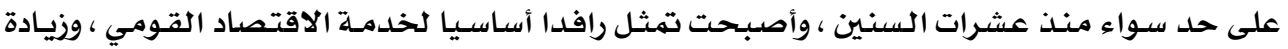

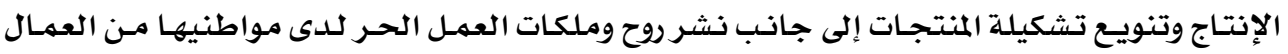

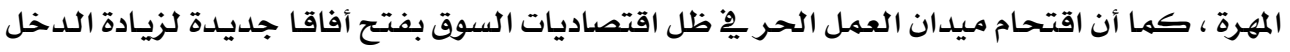

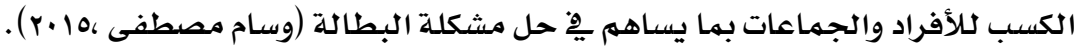

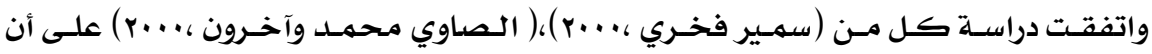

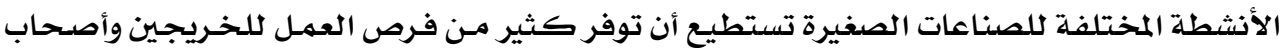

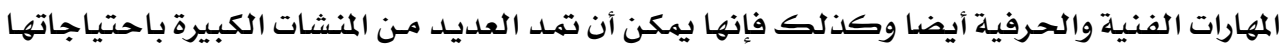

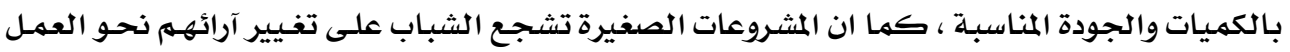

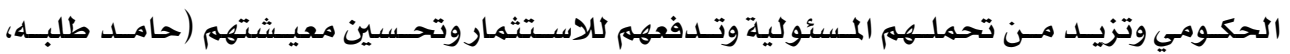

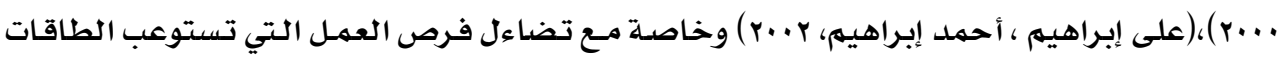

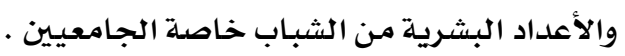

واليوم أصبتح التطريز عنصرا له أهميته يِّزخرفة الأقمشة سواء كان التطريز يدويا أو أليا

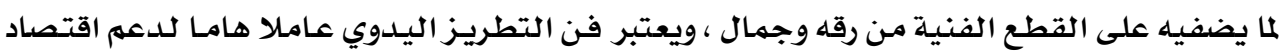

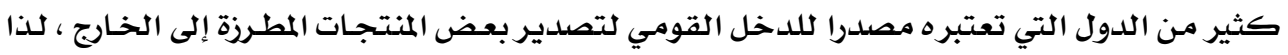

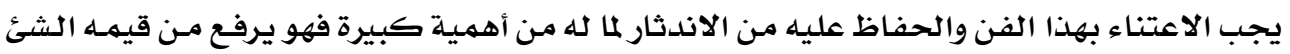

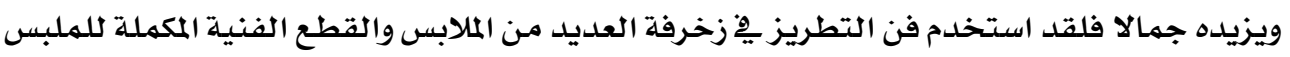

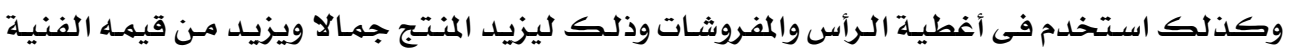

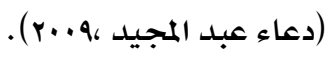

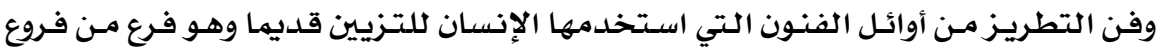

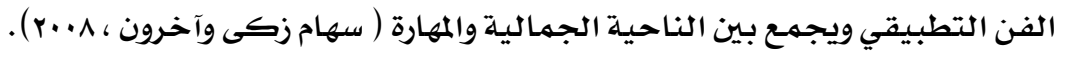

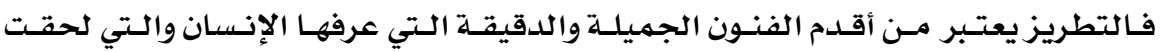

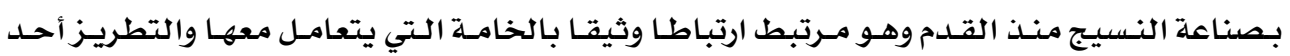

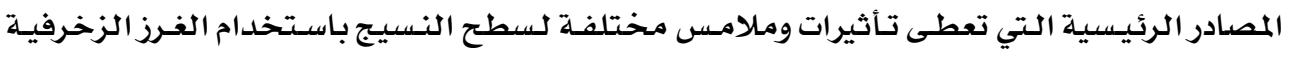

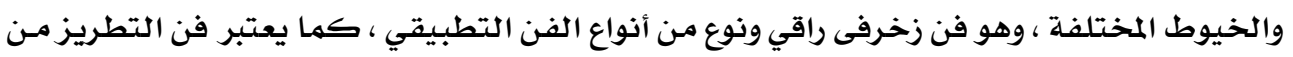

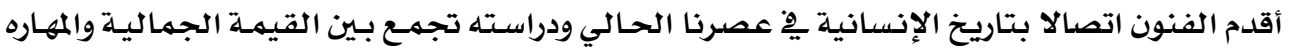

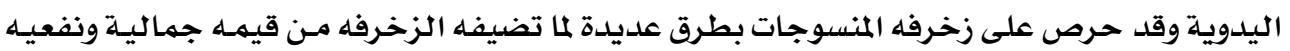

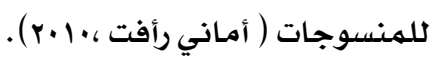

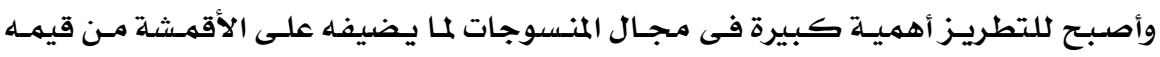

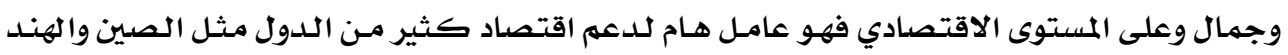

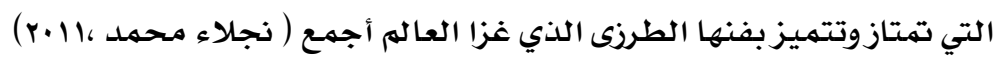


فمهمـا ظهـرت مـن آلات حديثـة ومتطـورة فى الخياطـة والتطريـز الالى ، فـالتطريز اليـــوي

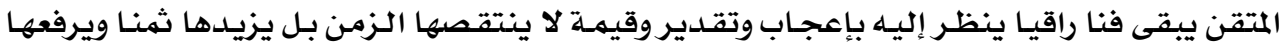

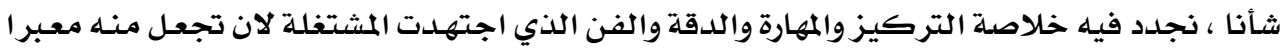

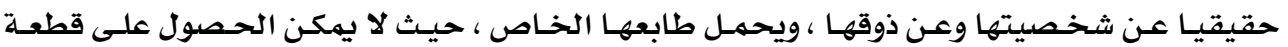

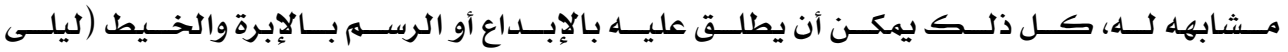

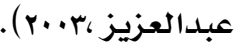

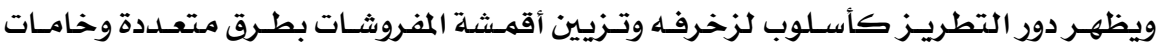

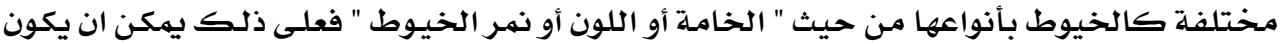

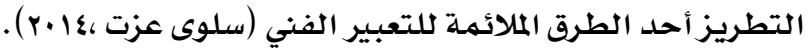
حيث تعتبر المفروشات أحد النوعيات الهامة التي تقوم صناعة المنسوجات بإنتاجها وتقديمها

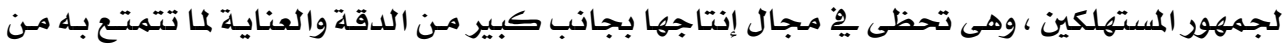

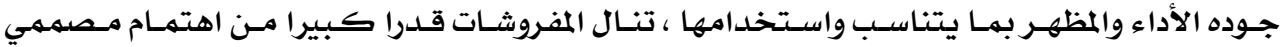

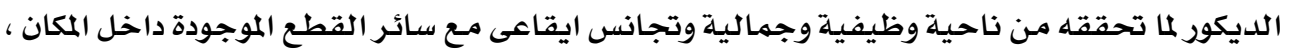

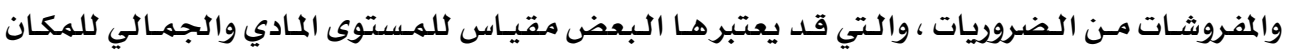

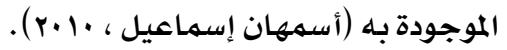

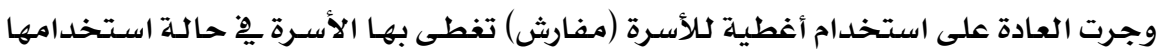

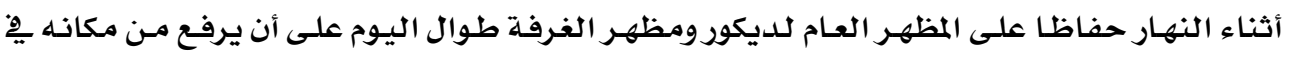

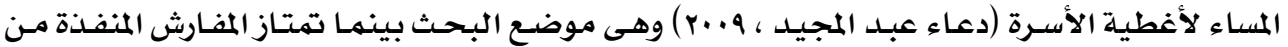

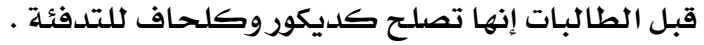

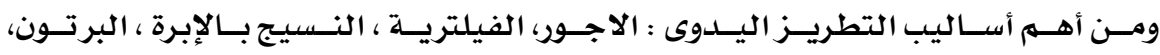

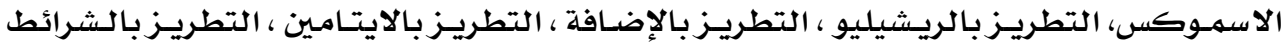

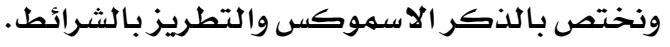

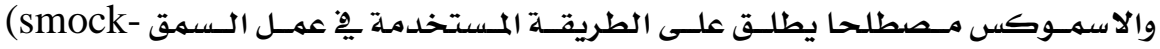

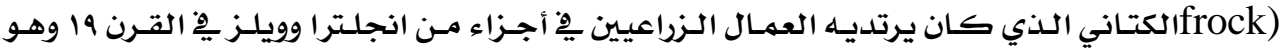

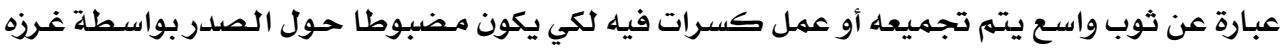

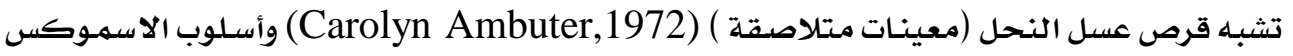

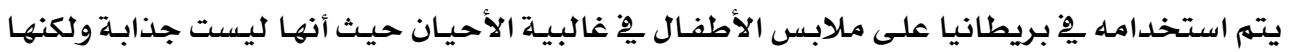

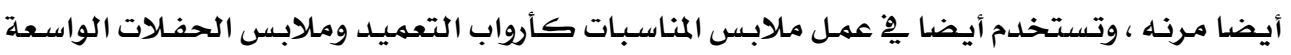

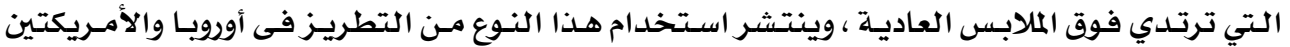

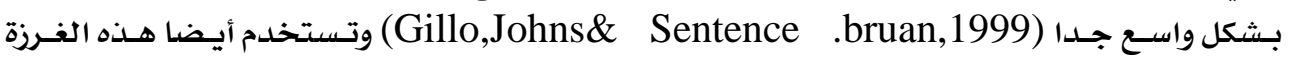
بأشكال متتنوعة على أماكن مختلفة منها الملابس الحريمى الخاصلة بالنوم مثل القمصان والجلاليب واليب 


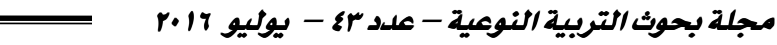

وعلى خط الوسـط لعمـل الكشكشة ، كمــر الجـونلات ، الغطـاء الخـارجى للوسـائد ، أسـاور البلـوزات ، الجيوب ، جيوب الشنط ، أو الشنطة بأكملها ، الستائر القصيرة ..الخ

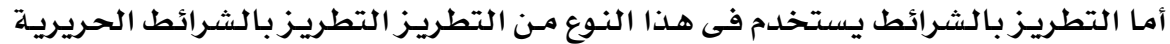
الرقيقـة بعـروض وألـوان متعـددة وكـلك أسـاليب مختلفـة فى التتفيـذ تطـرزبها الزهـور وأوراقها ،

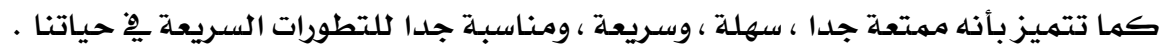
يعتبر التعليم من أهم المظاهر والسمات التي تلعب دورا حيويـا يِّ تقدم الكثير مـن الشعوب حيث انه يؤثر تأثيرا ايجابيا وثاملا يخ تنشئـة جيل جديد على أسس علمية متطورة وحلديثة ، ويقاس

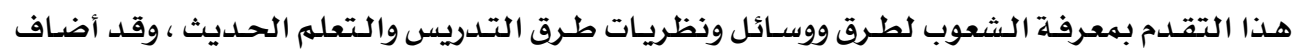

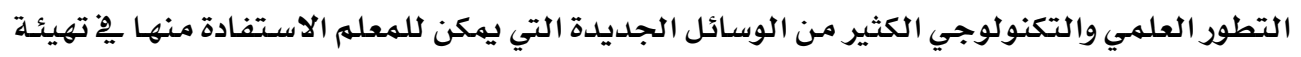

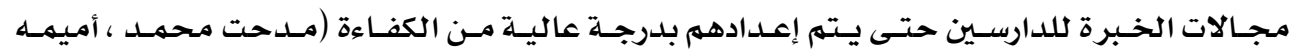
رووف، (r) (r)

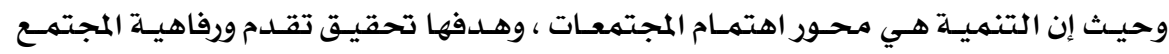

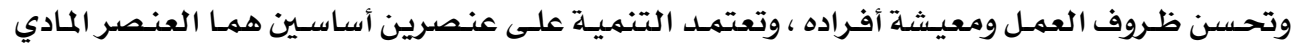
والعنصر البشرى ، ولا يهكن أن تحدث تنميـة يِ أي نشاط إلا بـارتباط العنصـرين وتكاملـهما معـا ، مهـا

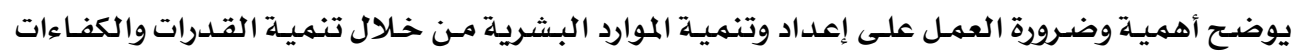
البشريـة علميا بتزويدها بـالمعارف والمعلومات والمهارات التي تزيد من قدراتهم الإنتاجيـة (إينـاس مـاهر ،

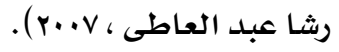

وفى دراسة (Dan William,1994) و(على السلهي ، 199V) أظهرت أن العائد الاقتصـادي للمشروع الصغير ونجاحه يتوقف على العديد من العوامل الهامة منها توافر الموارد المجتمعية والقـدرة على إدارة هذه الموارد وإمكانياته سواء كانت بشريـة أم مـاديـة والقدرة على تحمل المسئولية . وأكد كل من (سعد عبـد الرسـول ، (Donald,1991) ودراسـة (إن ضعف الإمكانيـات والافتقار الى المهارات وعدم قدره مـالك المشروع على إدارته من عوامل فشل المشروع مهـا يتطلسب إيجـاد

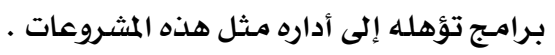
لذا يعد مـجال تطـوير المنـاهـج أمـرا حيويـا لكل مـن لـه صـله بعمليـة التربيـة وتعتبر البر امـج التدريبية أحد أشكال تطوير المناهـج فهي تعد بهثابة تنظيم يخطط له مسبقا يِ صورة كلية تتضمن المـادة التعليميـة والوسـائل والأنشطة التعليميـة المـــاحبـة وطـرق التــريس بـالإضـافة إلى عمليـات التقويه المستمـرة والتي تؤدى يِ مجموعه إلى بلوغ الأهداف المرجـوة ، ويحتاج ذلك إلى المرور بخبر ات معينـة يترتب عليها اكتسـاب المتعلم للهعلومـات والمهارات ، ويعتبر التجريـب يْ مجــال التطريـز مـن أهم الضرورات التي تحقق أهداف هذا المجال .

فالتـــريب أداه التتنميـة ووسـيلتها الـتي إذا أحسسن اسـتثمـارها وتوظيفهـا تمكـن مـن تحقيـق

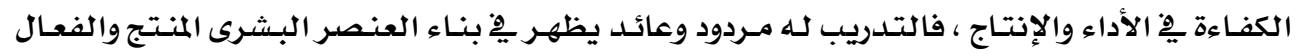


الذي يساهم بلدوره يِّ زيادة الكفاءة الإنتاجية على مستوى المنظمة ككل ، فهو نشاط مخطط يهدف

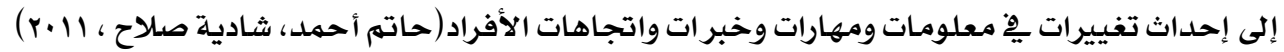

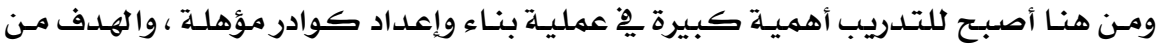

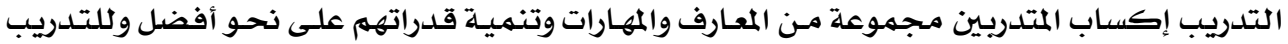

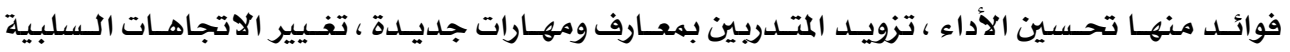

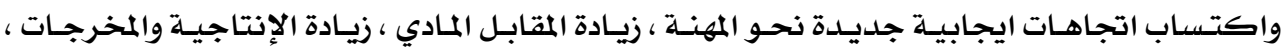

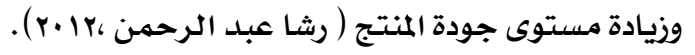

\section{ومما سبق تتحلد مشكلة البحث يِ الإجابة على التساؤلات الآتية :}

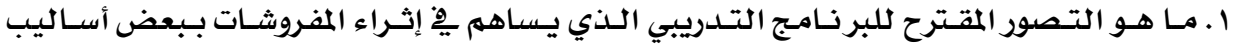

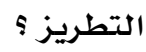

ץ . ما مدى فاعلية البرنامج يِّ اكتساب الطالبـات للمعارف المتضمنة بالبر نامج؟؟

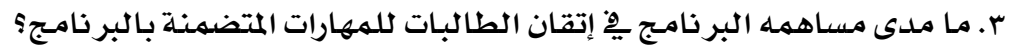

ع . ما إمكانية الاستفادة من البر نامجج يِ إنتاج مفروشات تصلح كصناعات صغيرة ؟

ا ـ تصميهم برنامج تدريبي لطالبـات الفرقة الثالثـة اقتصاد منزلي يهـدف إلى تـدريبهن على إنتاج

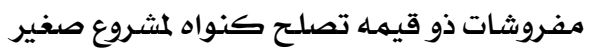

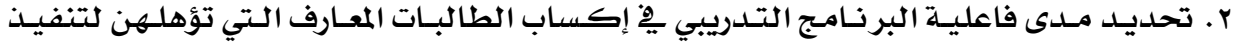

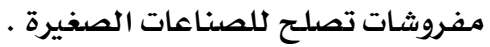

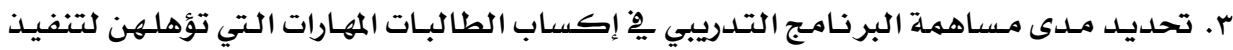

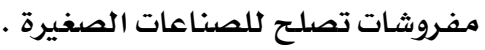

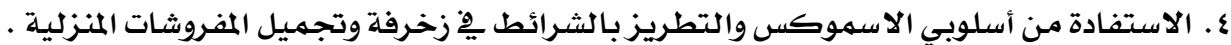

ه. إعداد وتدريب الطالبات لإكسابهن مهارات يتطلبها سوق العمل.

1. المساهمة يِّ حل مشكلة البطالة وكذلك تحسين المستوى الاقتصادي .

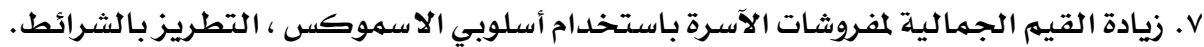

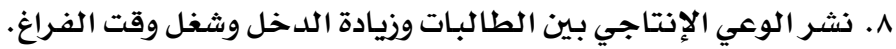

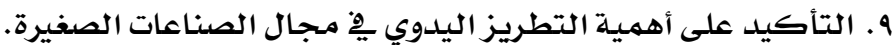

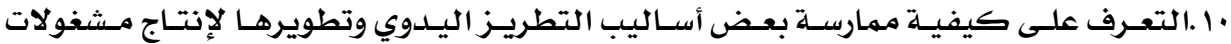

$$
\text { عصرية تصلح كصناعات صغيرة . }
$$

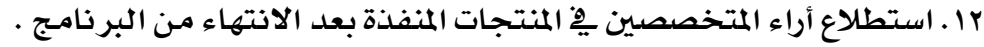

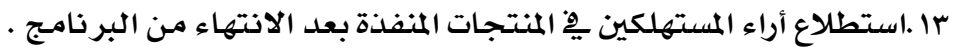

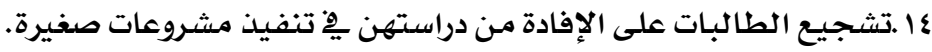




\section{أهمهية البحث:ث \\ ترجه أهمية البـحث إلى}

ا ـ تحديد أهم مهارات التطريز اللازمـة لإنتاج مفروشات منزلية تصلح للتسويق.

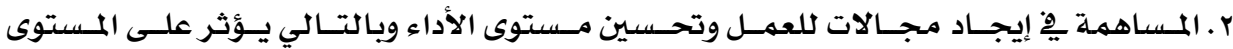
الاقتصادي لكلأسـر المصريـة.

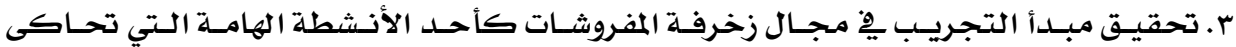
احتياجات المستهلك.

ع . إثراء مـجال زخرفة مفروشات الآسـرة بطريقة تعتمد على الأعمال اليدوية الزخرفية . ه فتح مجـالات عمل جلديدة والمساهمة يخ القضاء على البطانة وتخفيـف العسء الاقتصادي عن

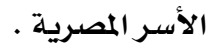

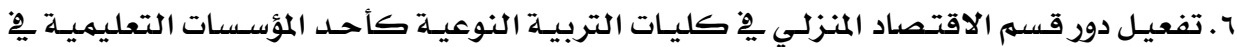

$$
\text { خدمـة وتطوير المجتمـع وسلد احتياجـاته. }
$$

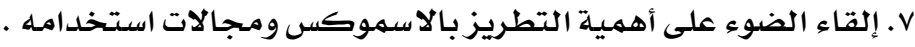

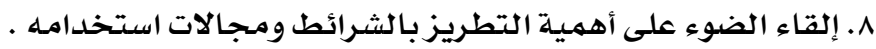

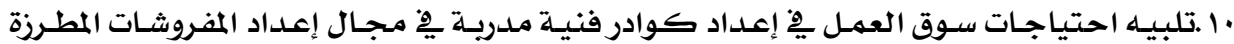

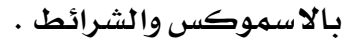

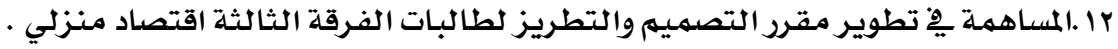

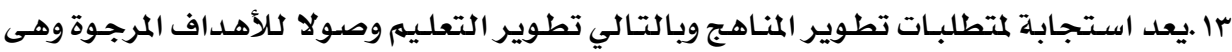
الصناعات الصغيرة مها يؤدى إلى تحسين دخل الأسـر المصرية .

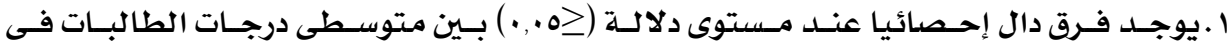

$$
\text { التطبيقين القبلي والبعدى لاختبار التحصيل المعريخٍ - لصالح التطبيق البعدي. }
$$

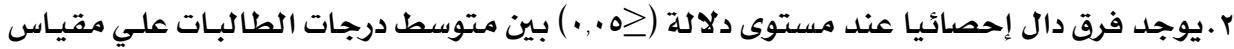
تقدير الأداء المهاري ومستوي التمكن ( •^٪) - لصالح درجات الطالبات.

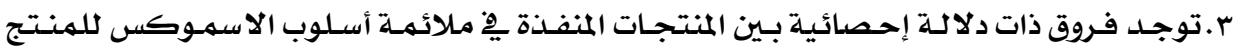
المنفذ وفقا لآراء المحكمـين"

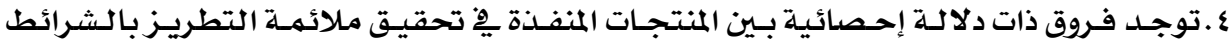
للمهنتج المنفذ وفقا لآراء المحكمـين" ه.توجد فروق ذات دلالة إحصائيـة بـين التصميمـات المنفـذة يخ تحقيق جـودة المفروثـات وفقـا لآراء المحكمـين

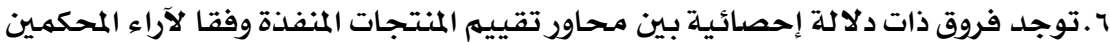
V.توجد فروق ذات دلالة إحصائية بين المنتجات المنفذة وفقا لآراء المحكمـين 


$$
\text { ^.توجد فروق ذات دلالة إحصائية بين المنتجات المنفذة وفقا لآراء المستهلكين. }
$$

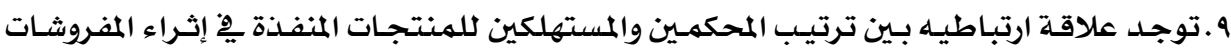

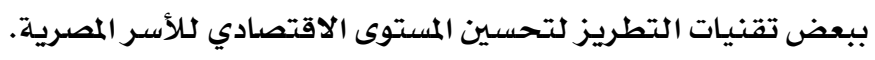

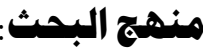

$$
\text { اتبع البحث المنهج الوصفي التجريبي لتحقيق الأهداف البحثية . }
$$

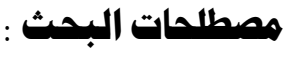

ا 1.الفاعلية :

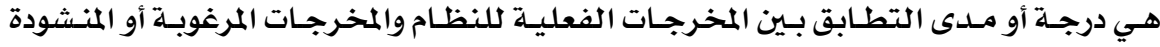

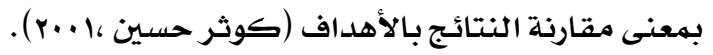

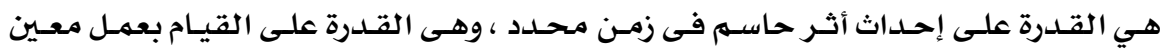

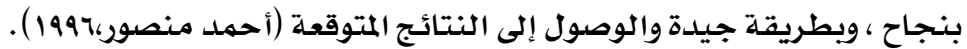

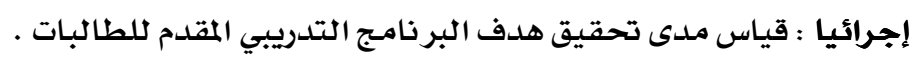

\section{program: البرنامج}

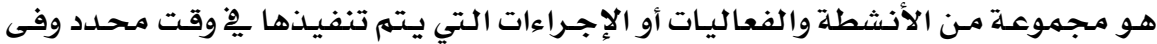

علاقات مخططة متتابعة ومتزامنة باستخدام موارد وتقنيات مناسبة ( على السلمى أ ، 199V) . مجموعة من المعارف والمفاهيهم والأنثطة الاجتماعيـة التعليميـة المتعلقـة بالمهارات الحياتيـة

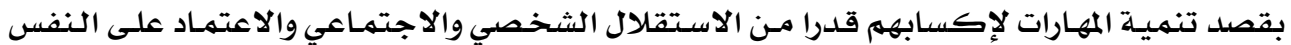

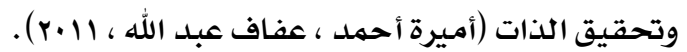

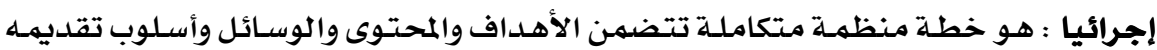

$$
\text { وطرق التقييه المختلفة . }
$$

بنيه مستقلة من مجموعة المهارات المراد إيصا لها إلى المتدرب والتي تصاغ وفق أسـلوب مـنظم

يبدأ بتحديد الأهداف وينتهي بعملية التقييم (WwW.wikipedia.com). إجرائيـا : مجموعـة المعلومـات والمهارات والقـدرات الخاصـة بـبعض أسـاليب التطريز لإعـداد

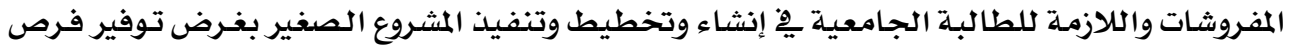

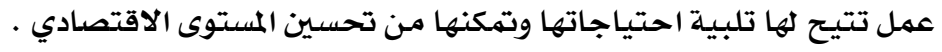

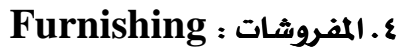

$$
\text { المفرش هو ما يفرش وينام عليه ( المعجم الوجيز ، ب...r). }
$$




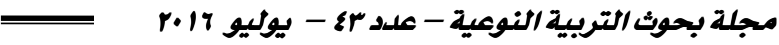

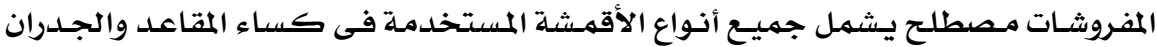

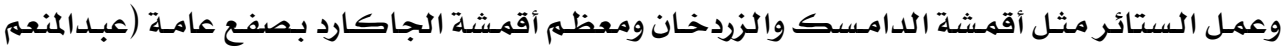

صبرى ، رضا صالح ، 19v0).

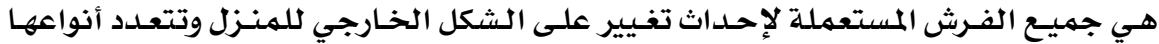

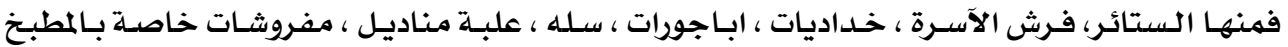

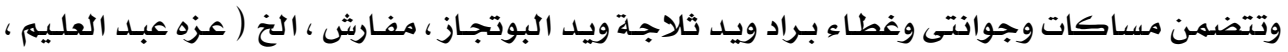

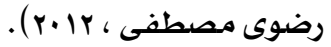

\section{Embroidery: التطريز}

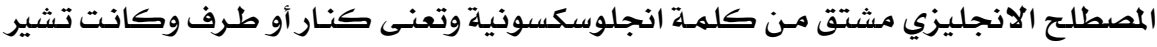

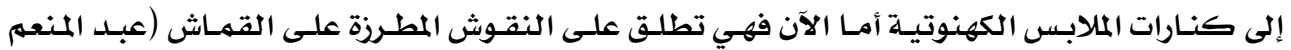

صبري ، رضا صالح ، 19v0).

- زخرفة القماش بعد أن يتم نسجه بواسطة ابره خاصة يختلف سمكها وطولها وحجمها

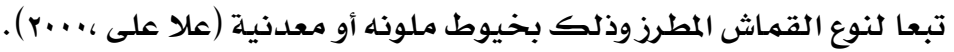

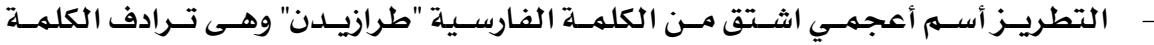

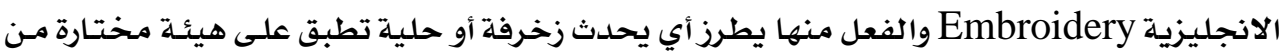

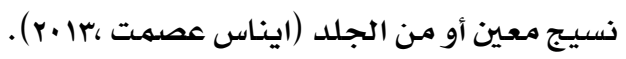

1. الاسموكس :

هو عبارة عن أسلوب من أساليب التطريز يحتوى على غرز ذات تكوين جميل وذلك بواسطة

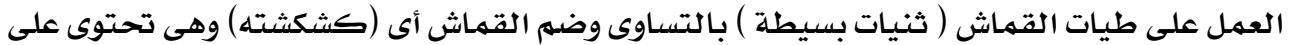

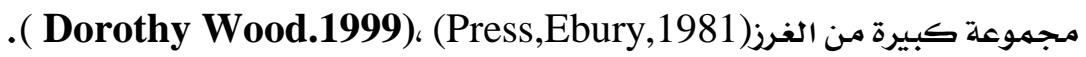

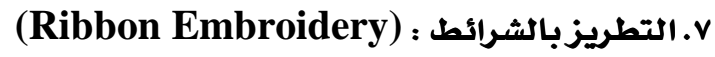

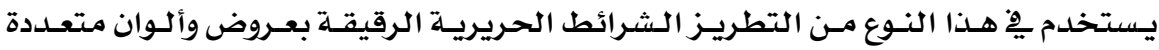

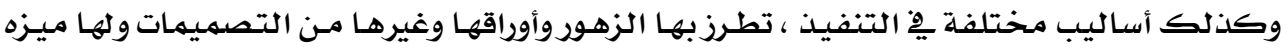
إبراز التصميم بشكل ثلاثي الأبعاد .

Small Projects : الصناعات الصغيرة

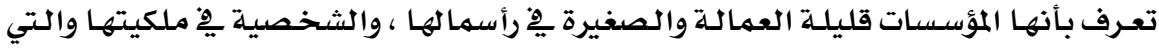

تنتج لغرض السوق المحلية بالأسـاس ولا تحتاج إلى تقنية راقيـة للغايـة أو لإدارة ضـخمـة (رهـام محمهود

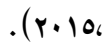




\section{يقتصر هذا البحث على :}

ا.الحـد البـشـرى / طالبـات الفرقـة الثالثـة بكليـة التربيـة النوعيـة جـامعـة المنـصورة وعـددهم Yr

$$
\text { طالبـة. }
$$

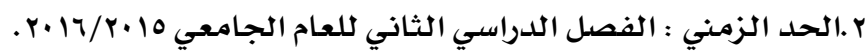
r. الحد المكاني : كلية التربية النوعية جامعة المنصورة .

ع. الأسـاليب المستخدمة للتطريز / فن الاسموكس ، التطريز بالشرائط .

\section{تكونت عينة البحث من :}

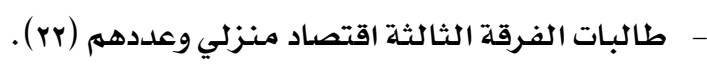

- محكمي الاختبار المهارى من خلال مقياس التقدير وعددهم (r).

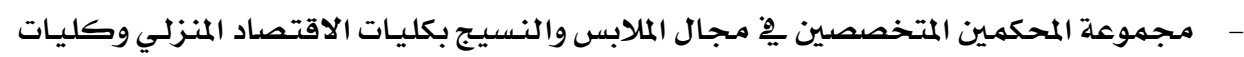

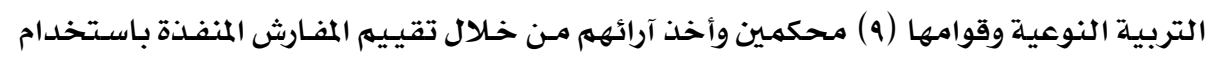

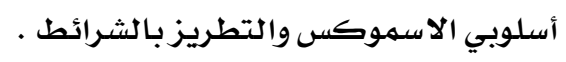

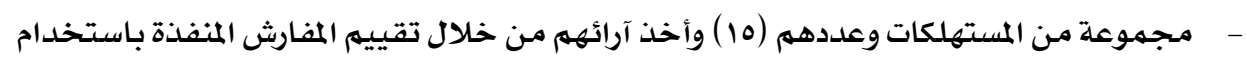

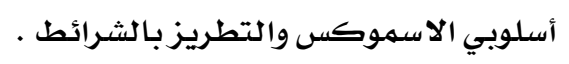

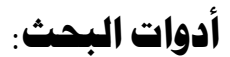

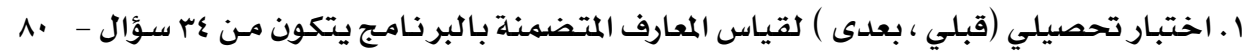

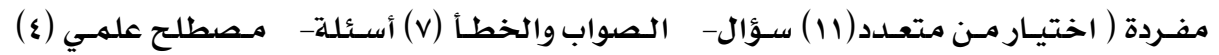

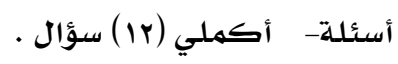

r. r. مفتاح التصحيح

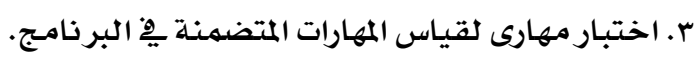

ع. مقياس تقدير لتقييم الاختبار المهارى ويتكون من ثلاث محاور :

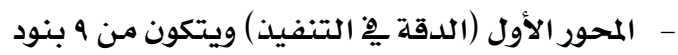

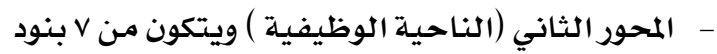

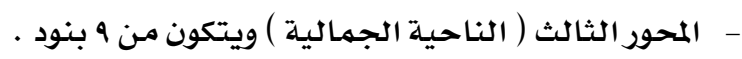

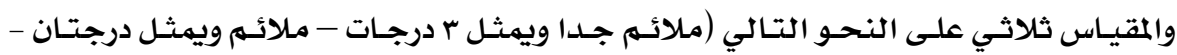

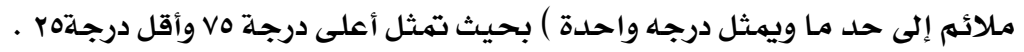


ه. استمارة تقييم المنتجات المنفذة (المفروشات) من قبل المتخصصين وعددهم (ه) وتتكون من ثلاثة محاور :

- المحور الأول ملائمسة أسلوب الأسموكس للمنتج المنفذ المفروشات ويتكون من ج بنود

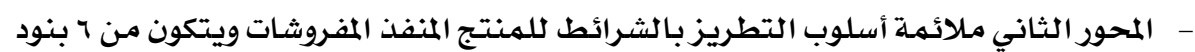

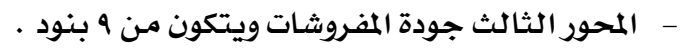

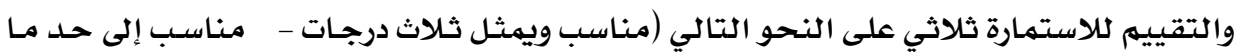

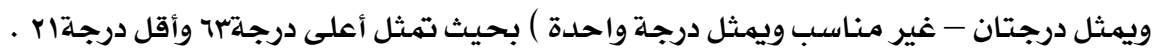

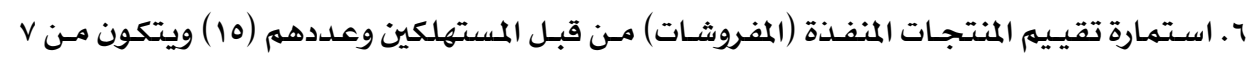

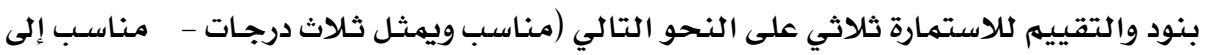

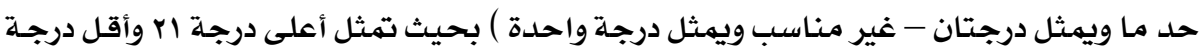

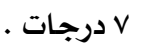

\section{الدراسات السابقة : العات :}

\section{أولا : دراسات اهتمت بالبرامج التدريبية والتدريب :}

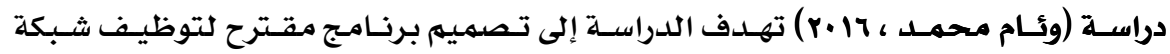

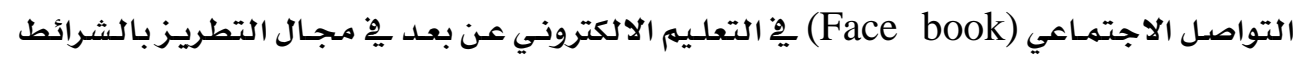

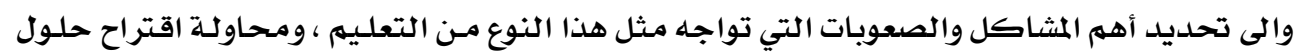

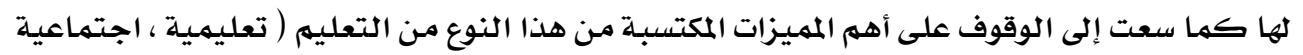

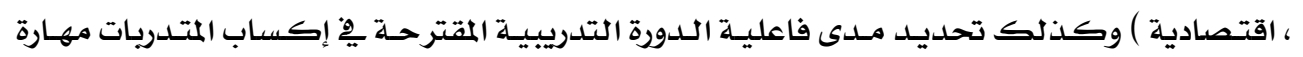

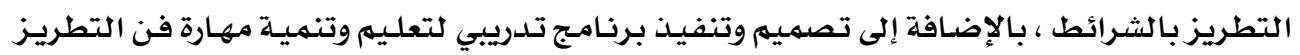

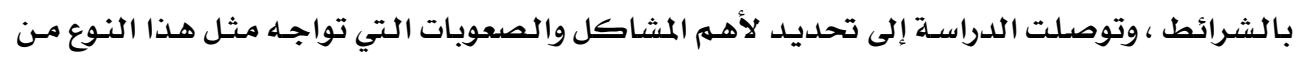

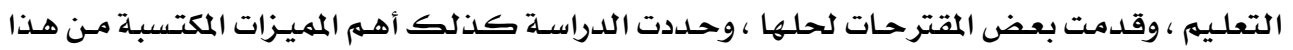

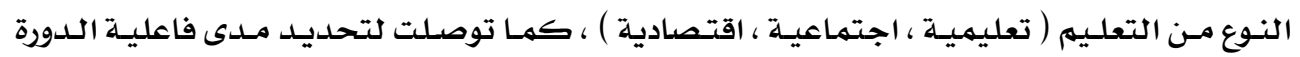

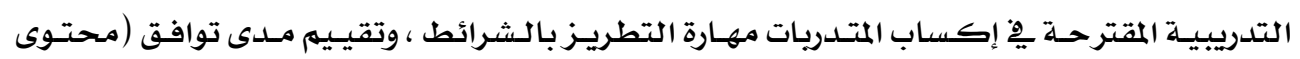

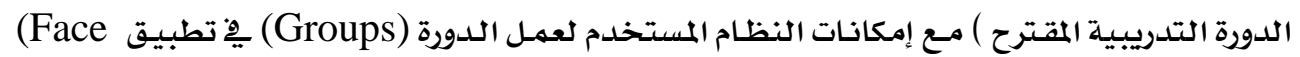
.book)

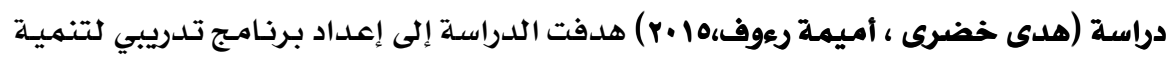

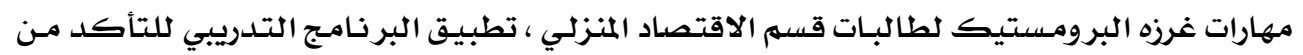

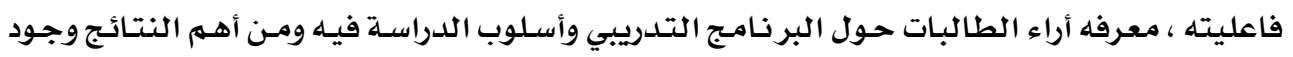

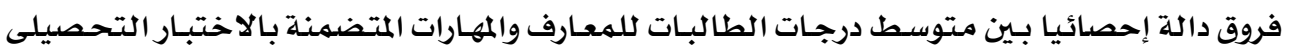

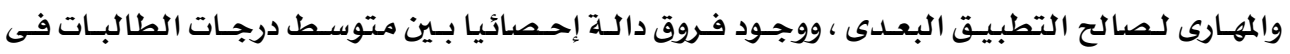

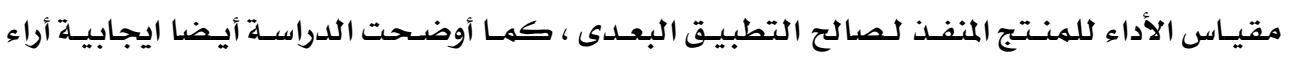

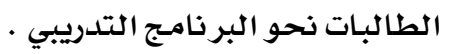




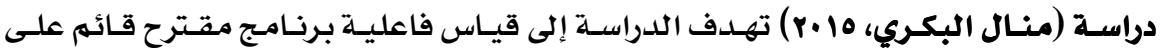

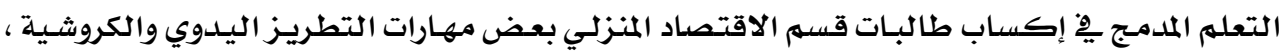

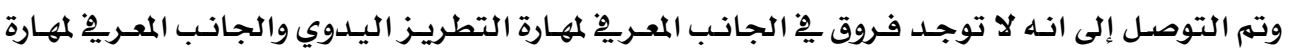

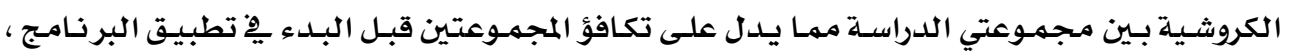

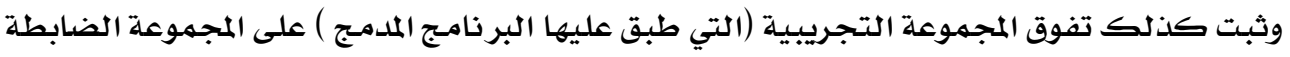

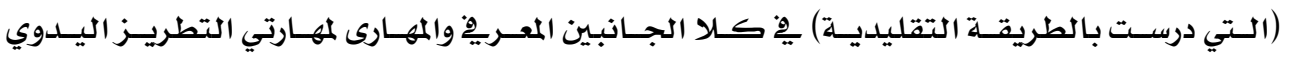
والكروشية.

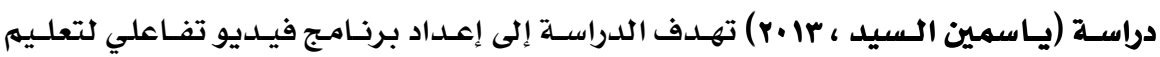

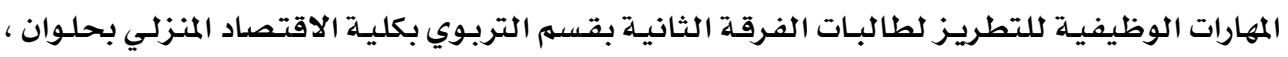

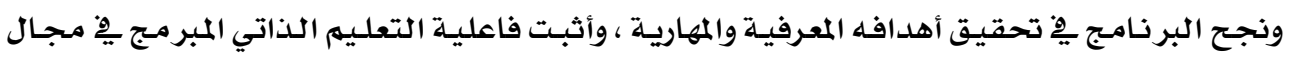
التطريز اليدوي.

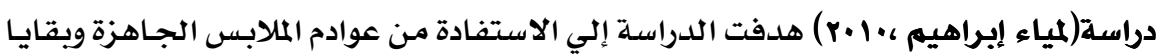

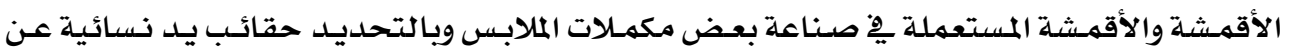

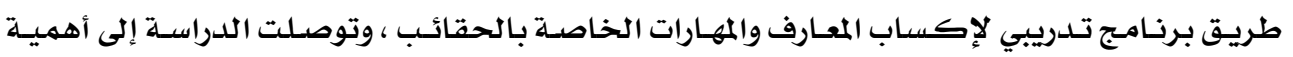

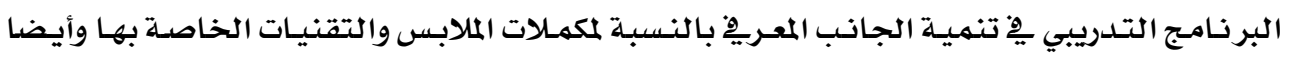

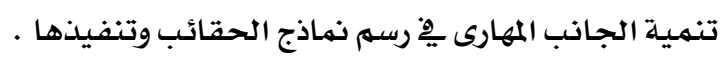

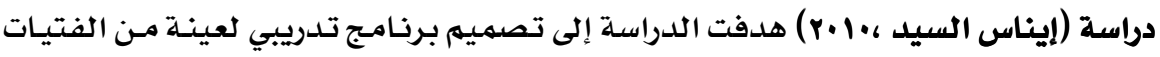

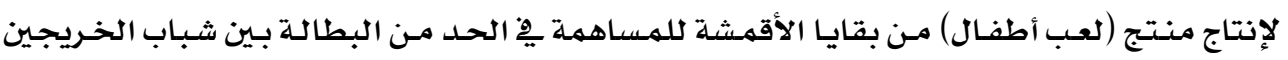

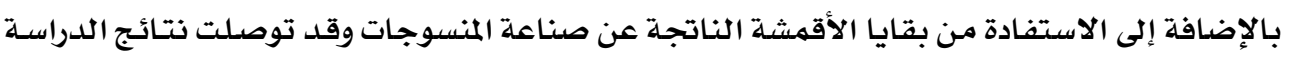

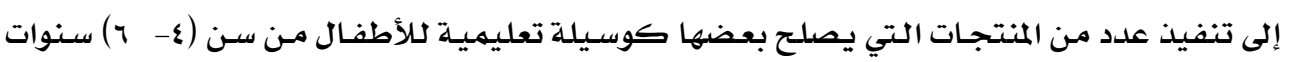

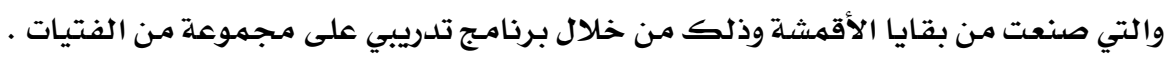

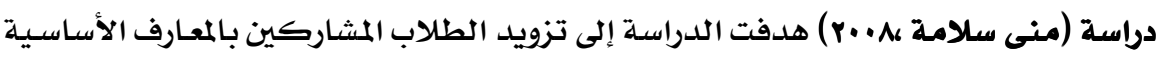

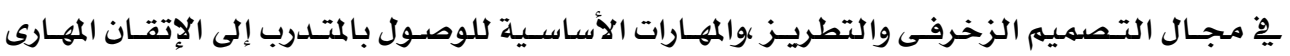

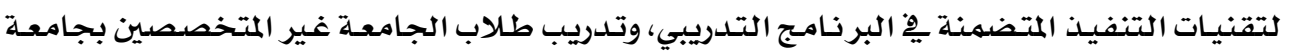

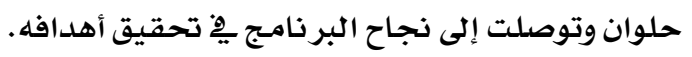

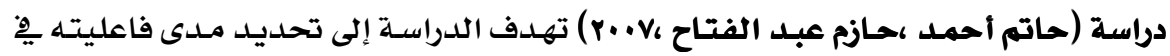

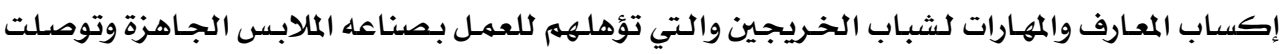

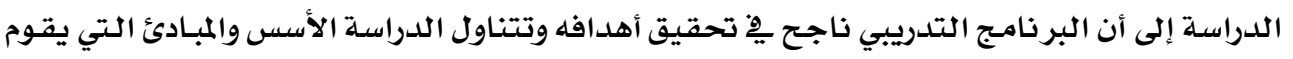

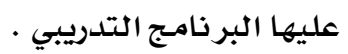
دراسـة (Ross Lawrence peckford,2000) تبرز الدراسـة دور التـدريب يِّ تنميـة الموارد البشرية عن طريق منظمـة تنميـة الموارد البشرية (HRDC) ِِّن نيولاند ولابـرادوروالتي تهتهم 


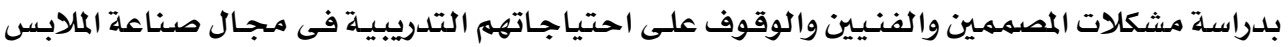

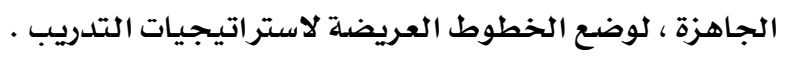
ثانيا : دراسات اهتمت بالمفروشات : التوضع الخطوط العريض

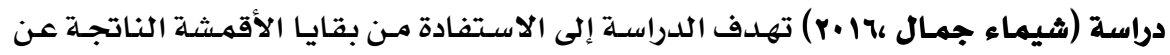

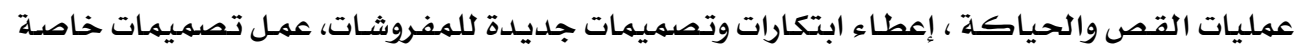

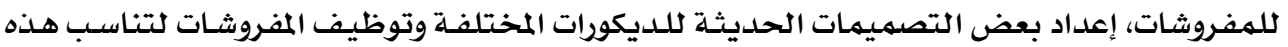

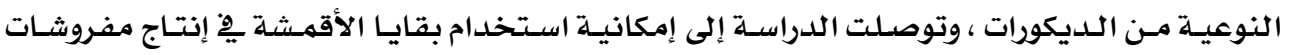

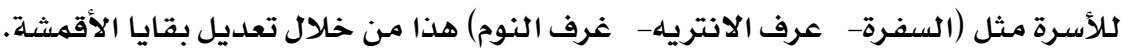

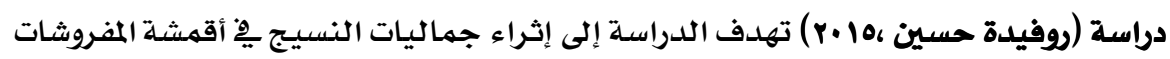

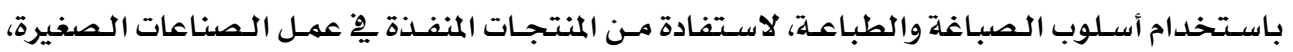

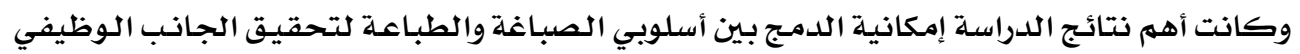

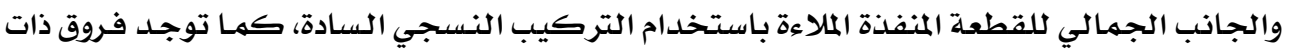

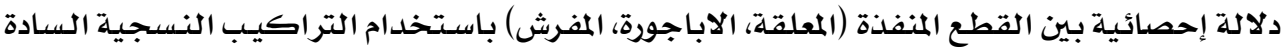
المبردى الاطلسى يْ تحقيق الجانب الوظيفي والجمالي.

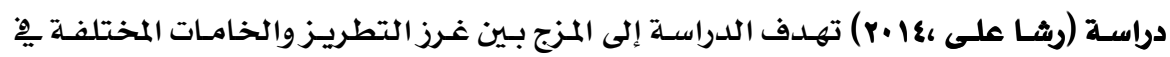

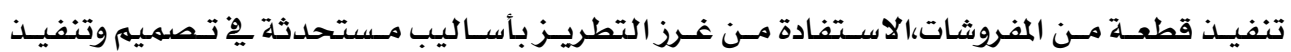

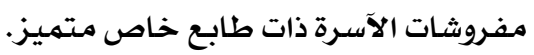

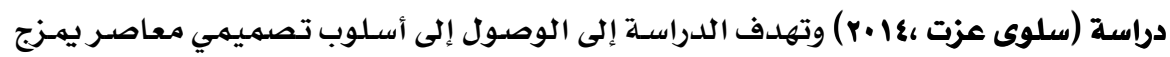

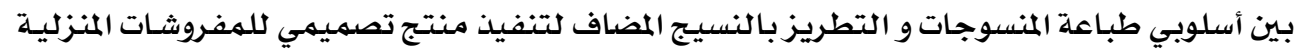

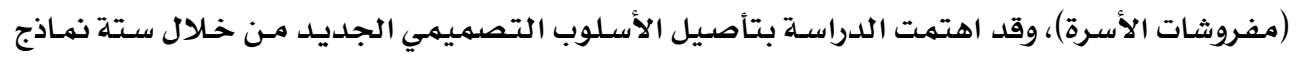

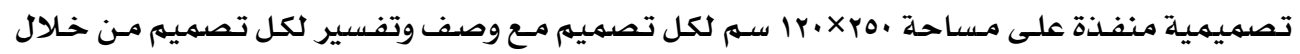
عرض لتفاصيلها الدقيقة مما أدى ذلك لإثراء تصميمات مفروشـات الأسـرة باعتبارهـا عاملا ملا أساسيا مِِّ إضافة القيم الجمالية للهنزل

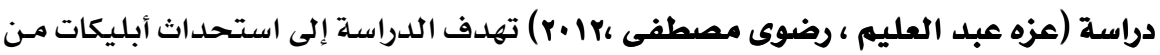

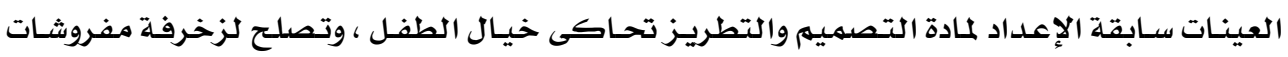

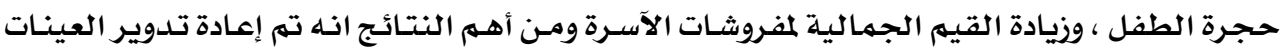

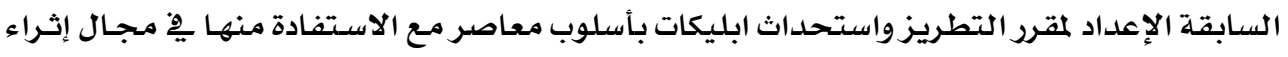
المفروشات . الإبقة الإن

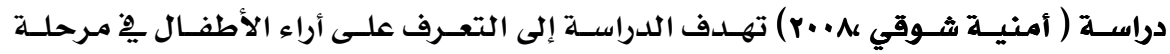

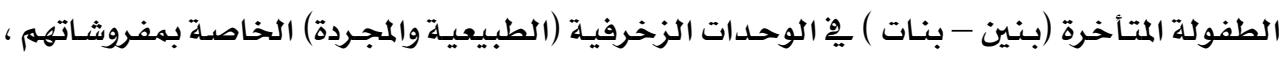

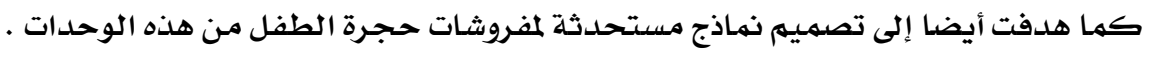




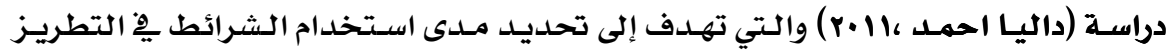

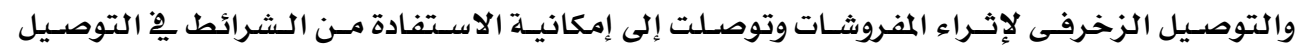

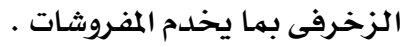

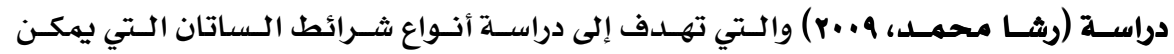

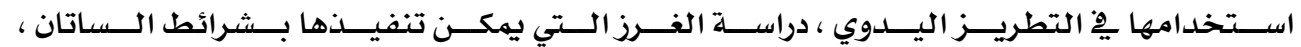

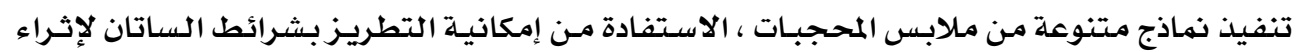

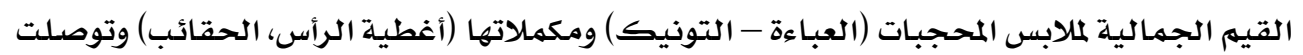

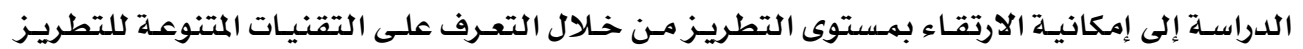

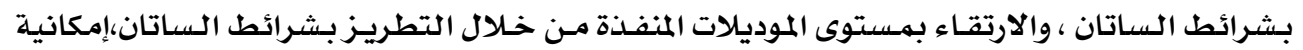

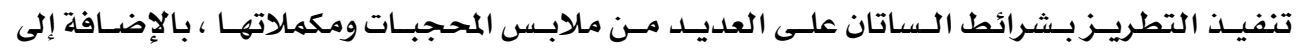

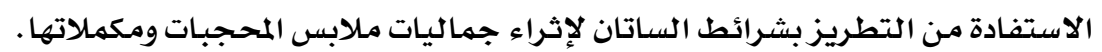

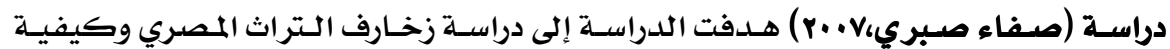

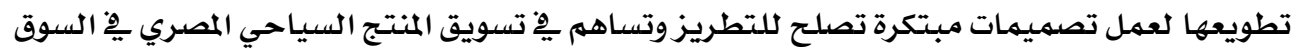

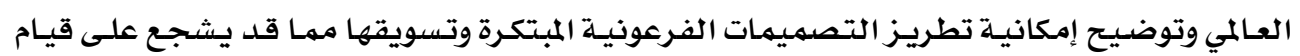

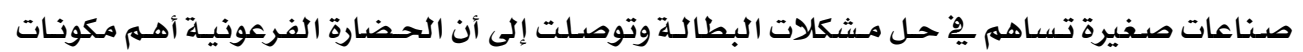

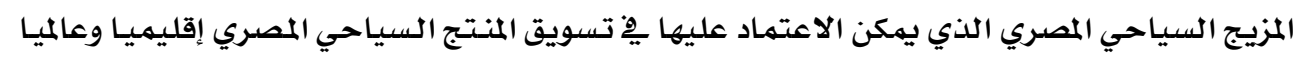

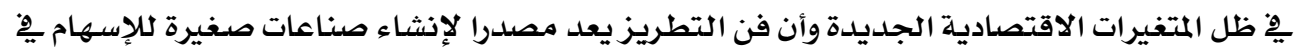

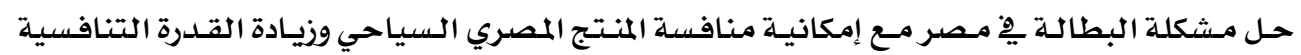

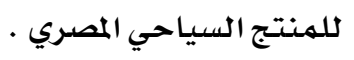

دراسة (هالة سليمان ، ع..r. ) والتي هدفت إلى دراسة بعض أساليب التطريز المختلفة وطرق

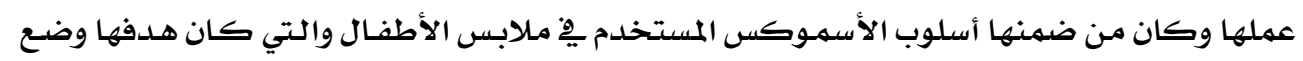

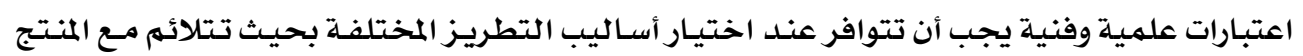

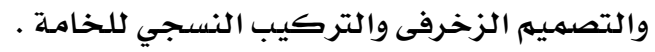

رابعا : دراسات اهتمت الصناعات الصفيرة :

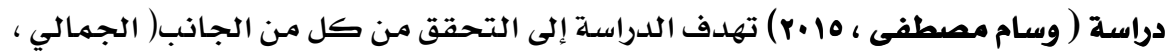

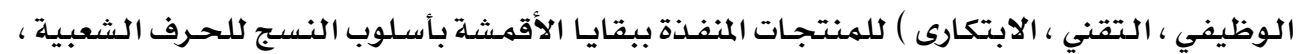

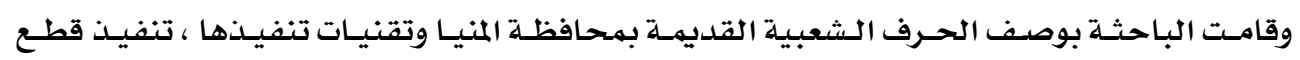

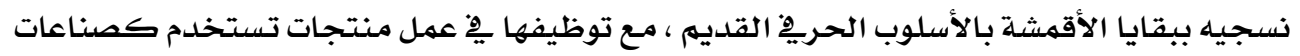
صغيرة . نسجة دراسـة (منار محمد ، 10 10 ) تهدف الدراسـة إلي ابتكار أساليب جديدة لتطوير مجال صناعة

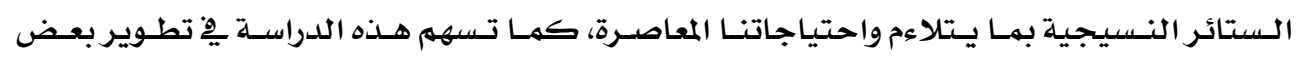




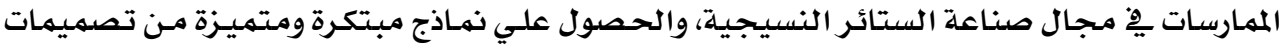

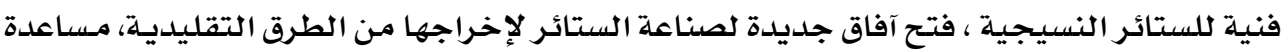

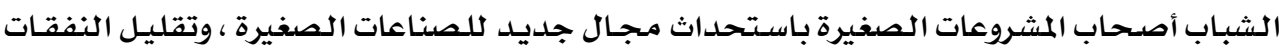

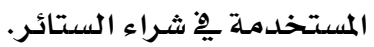

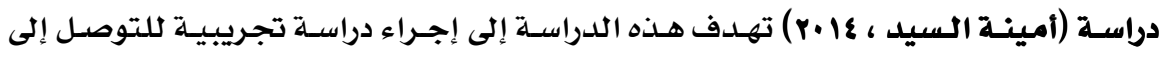

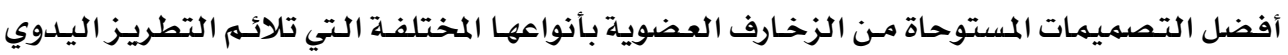

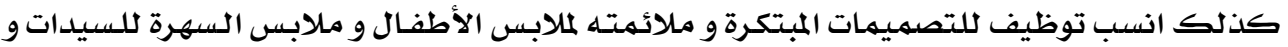

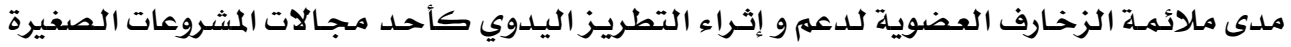

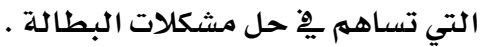

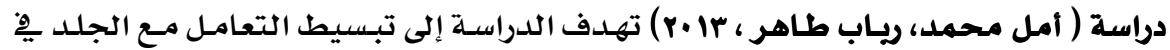

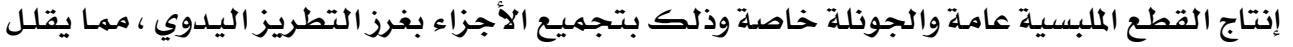

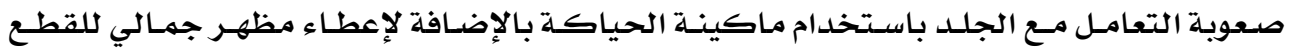

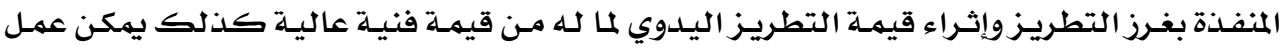

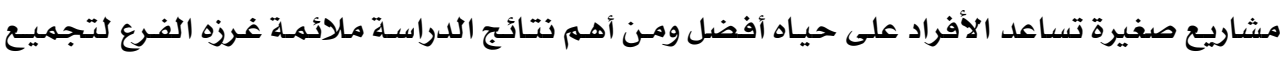

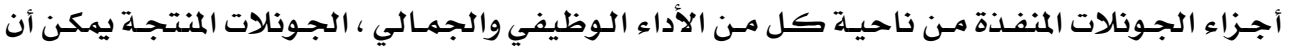

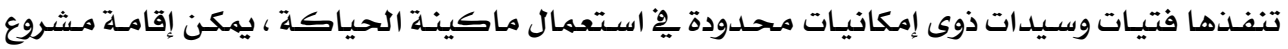

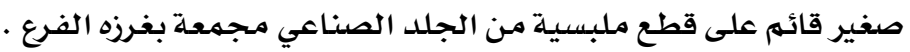

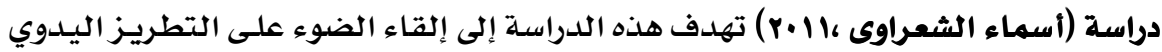

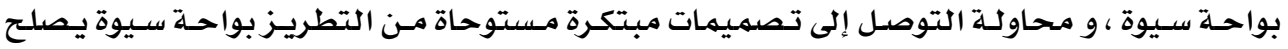

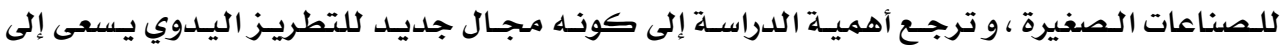

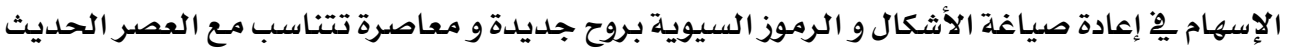
و تسـاعد على إثراء مجال الصناعات إعاء الصغيرة.

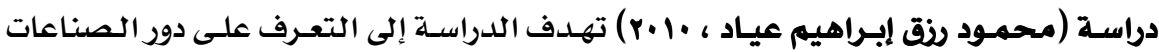

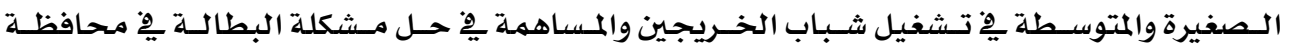

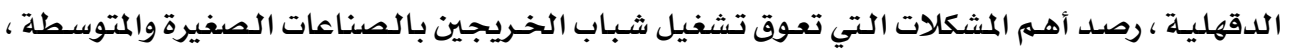

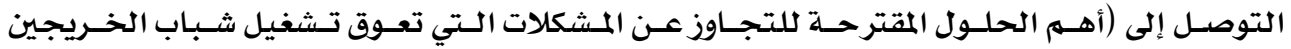

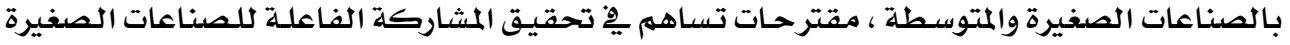

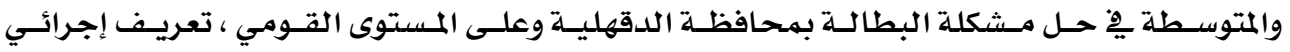

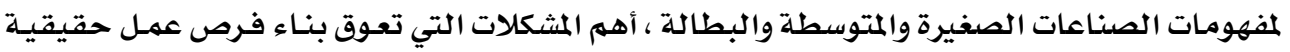

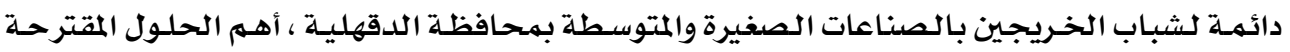

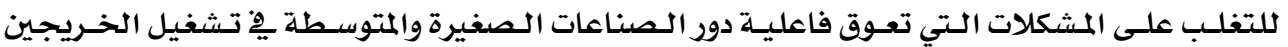

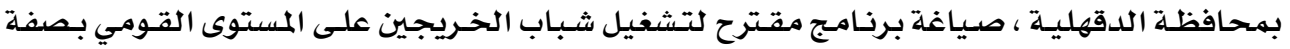




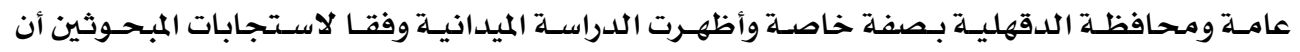

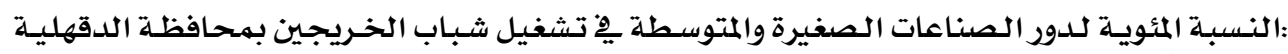

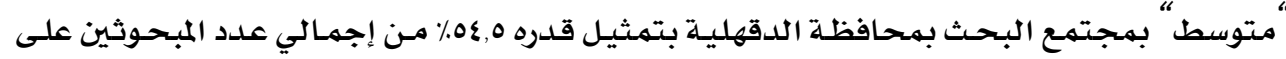

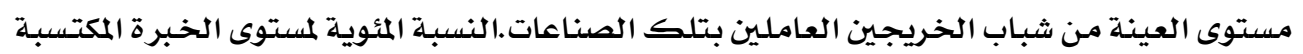

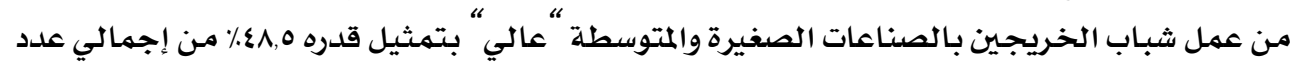

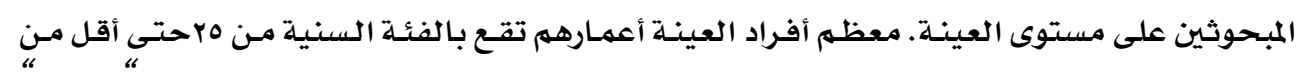

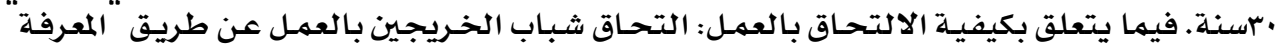

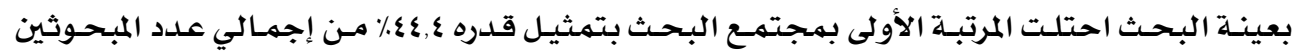

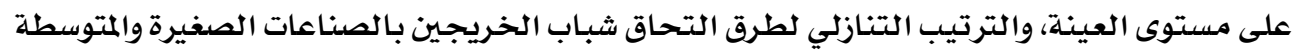

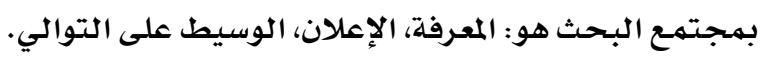

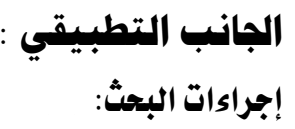

$$
\text { أولا : إعداد البرنامج التدريبي : }
$$

قامـت الباحثة بإعـداد برنـامج تـدريبي لإثراء المفروشـات بـبعض أسـاليب التطريـز لتحسين

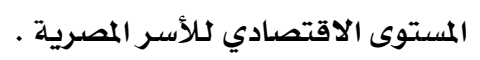

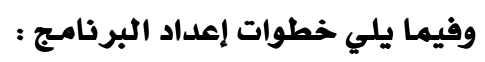

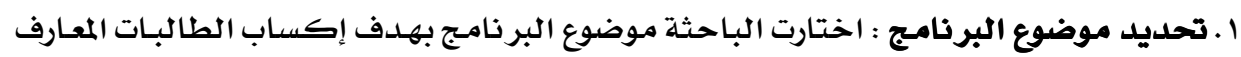

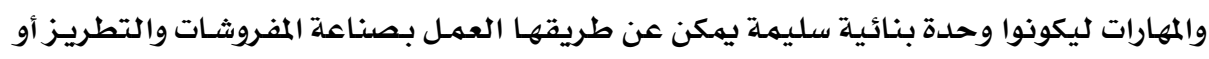

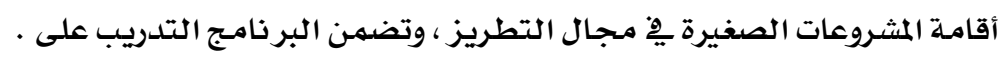

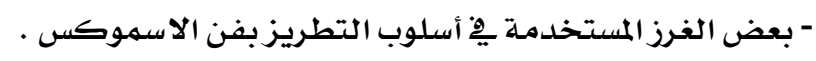

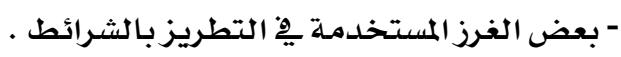

- تنفيذ بعض المفروشات المنزلية ( المفارث ) .

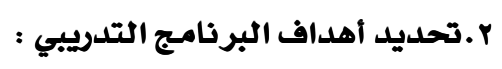

\section{- الأهداف العامة للبرنامـج :}

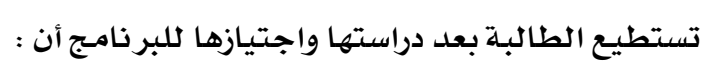

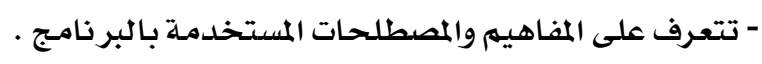

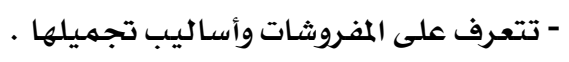

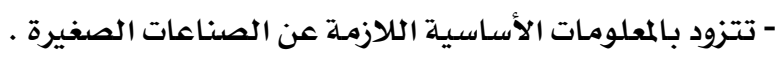

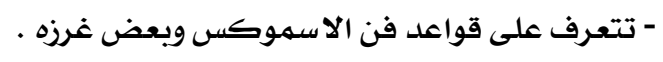

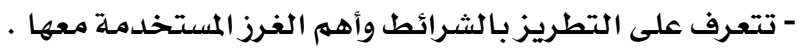

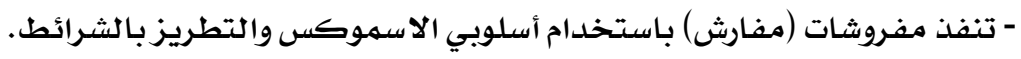




$$
\text { - الأهداف الإجرائية للبرنامـج : }
$$

هِ نهايـة دراسـة البر نامـج تصبيح الطالبـة قادرة على أن:

أ- الأهداف المعرفية : التي تهتم بالمعلومات والحقائق :

- توضح مفهوم الصناعات الصغيرة.

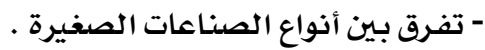

- تذكر أهم أبعاد الصناعات الصغاع الصناعات الصفيرة - توفيرة

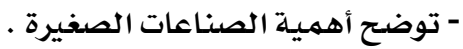

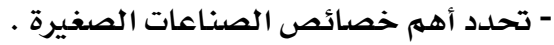

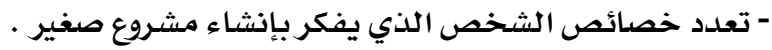

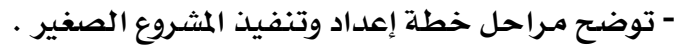

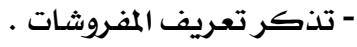

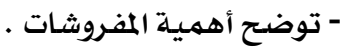

- تعدد استخدامات أقمشة المفروشات .

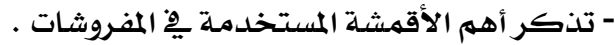

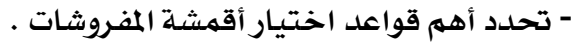

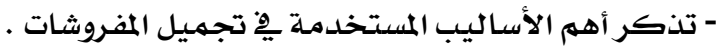

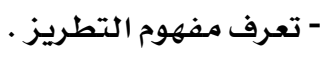

- تتعرف على الفرق بين التطريز بالشرائط والأسموكس.

$$
\text { - تعرف مفهوم الاسموكس الفرق بين التصري }
$$

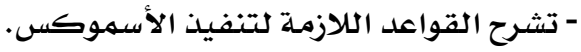

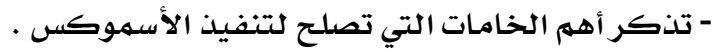

- تفرق بين الغرز المستخدمة في فن الاسموكس التهب.

- تعدد بعض الغرز المستخدمة بِ يْ الاسموكس.

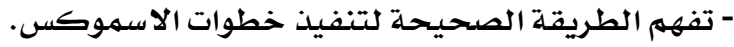

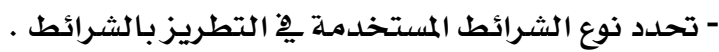

- تتعرف على أهم سمات شرائط الساتان . توند

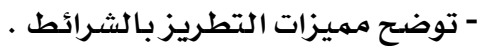

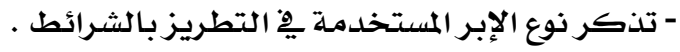

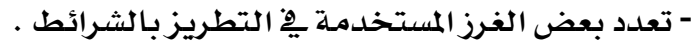

ب- الأهداف المهارية (الحركية) : التي تهتم باكتساب المهارات :

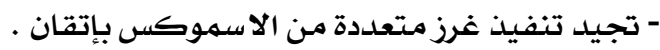

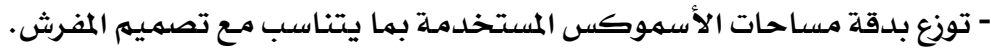


- تحدد مقاسات غرزه الاسموكس بما يتناسب مع تصميم المفرث.

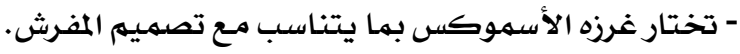

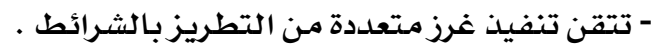

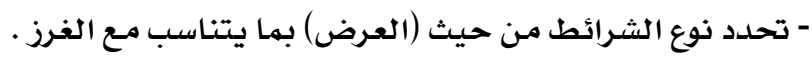

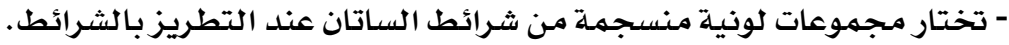

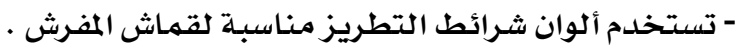

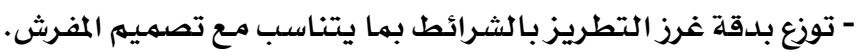

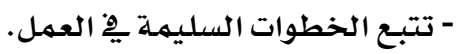

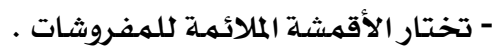

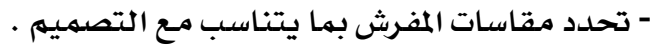

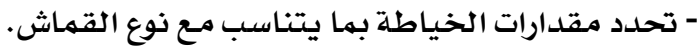

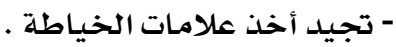

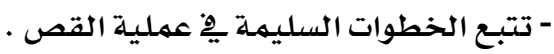

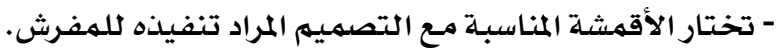

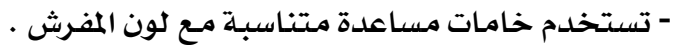

- تختار خامات منسجمة لونيا عند تنفيذ المفرث.

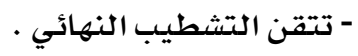

- تبتكر أثناء إخراج المفرث وتثطيب النهاتي •

ج- الأهداف الوجدانية: التي تهتم باتجاهات الطالبات نحو البر نامـج التدريبي :

- تصغ باهتمام أثناء الشرح.

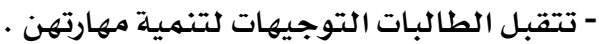

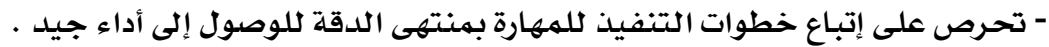

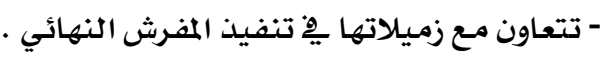

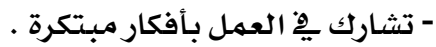

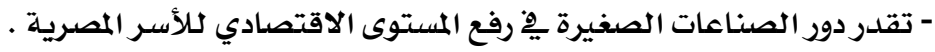

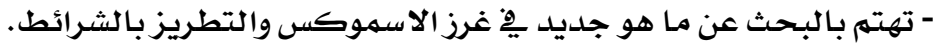

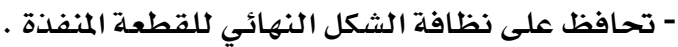

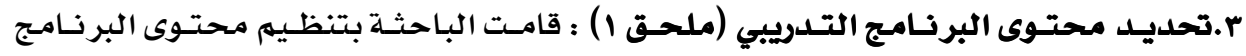

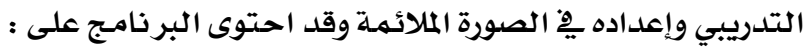

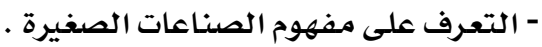

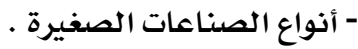

- أبعاد الصناعات الصغيرة . - أصناعات الهعيرة .

$r$. 


$$
\begin{aligned}
& \text { - أهمية الصناعات الصغيرة . }
\end{aligned}
$$

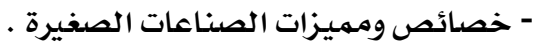

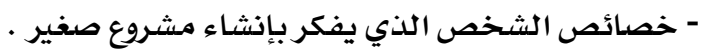

$$
\begin{aligned}
& \text { - مـراحل خطة إعداد وتنفيذ المشروع الصغير . }
\end{aligned}
$$

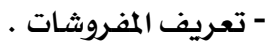

$$
\begin{aligned}
& \text { - أهمية المفروشات المبرتيات }
\end{aligned}
$$

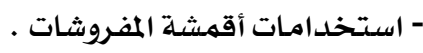

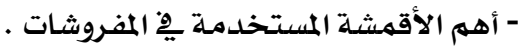

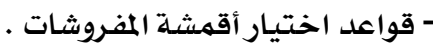

$$
\begin{aligned}
& \text { - الأساليب المستخدمة يِّ تجميل المفروشات . } \\
& \text { - تعريف التطريز - }
\end{aligned}
$$

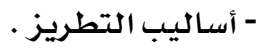

$$
\begin{aligned}
& \text { - مفهوم الأسموكس التطريز . }
\end{aligned}
$$

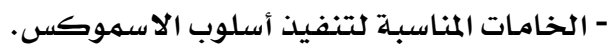

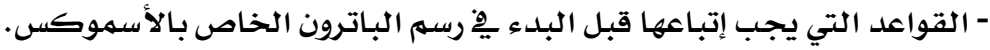

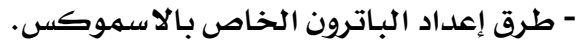

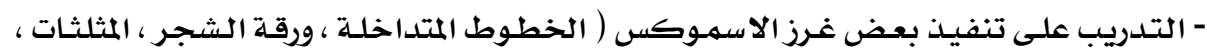
الزهرة ، زهرة الياسمـين المقلوبـة ).

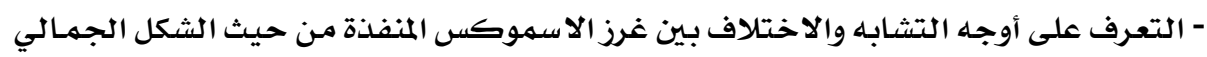

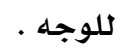

$$
\begin{aligned}
& \text { - تعريف التطريز بالشرائط . } \\
& \text { - سمات شرائط الساتان . }
\end{aligned}
$$

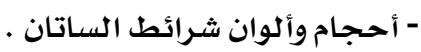

$$
\begin{aligned}
& \text { - طريقة نظم الخيط وعقده . }
\end{aligned}
$$

- التدريب على تنفيذ بعض الغرز المنفذة بالشرائط ( السلسلة ، غرزة المرجريت ، وردة الجـورى،

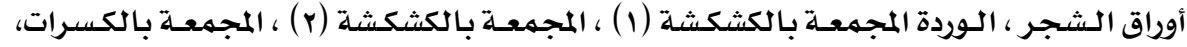

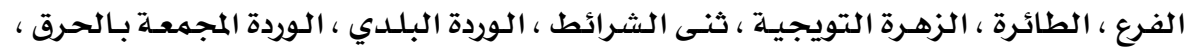

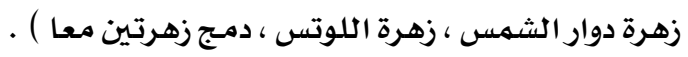

- تنفيذ عدد V مفرش باستخدام القواعد والأسس الكلازمة لتنفيذ المفروشات وأساليب التطريز. وقـد قامـت البـاحثـة بتنظـيهم محتــوى البرنـامـج بـصورة منطقيـة مـع مـراعـاة الترابط بــين 


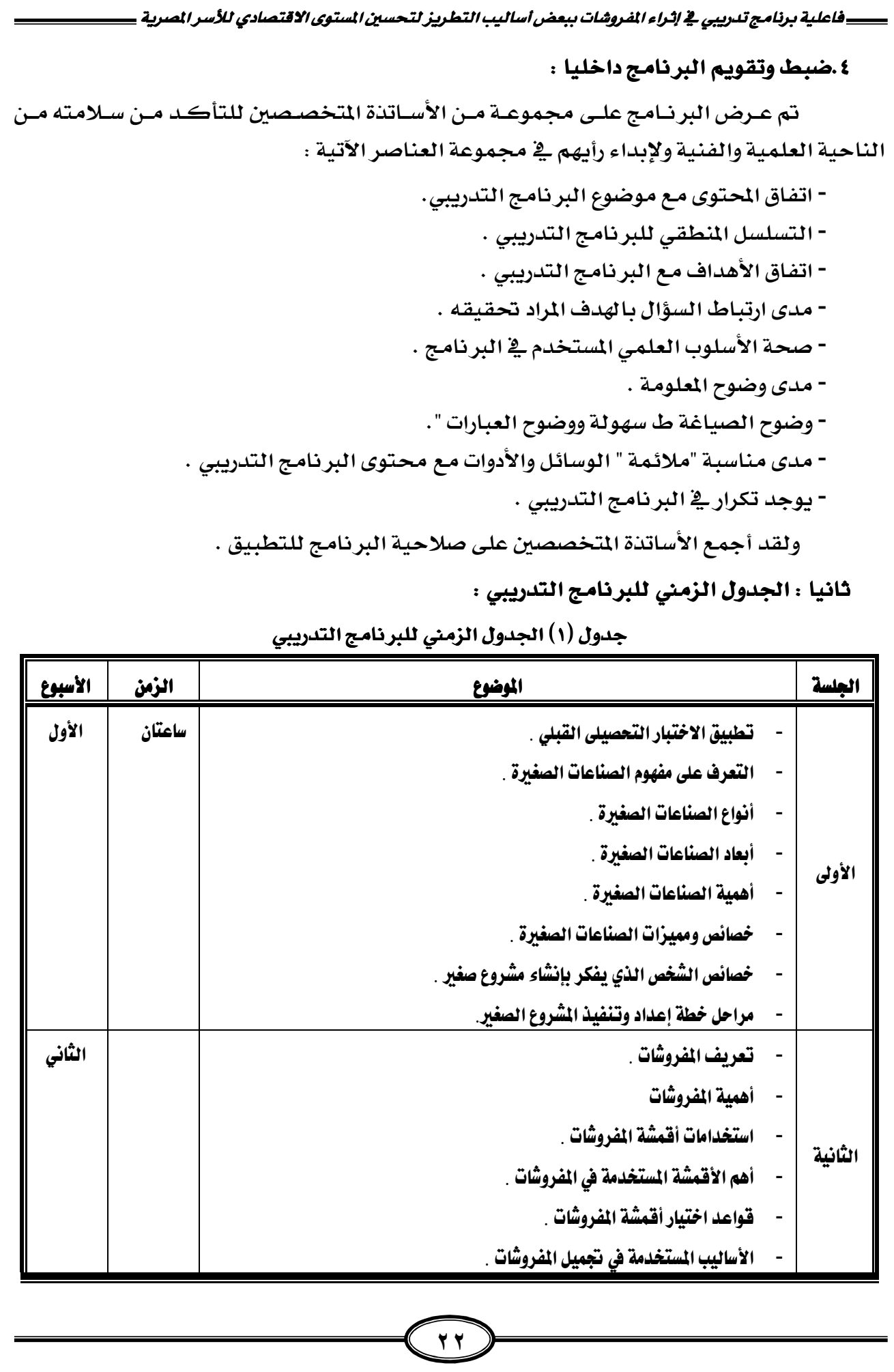




\begin{tabular}{|c|c|c|c|}
\hline الثالث & 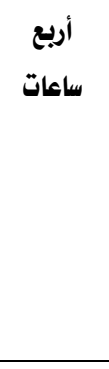 & 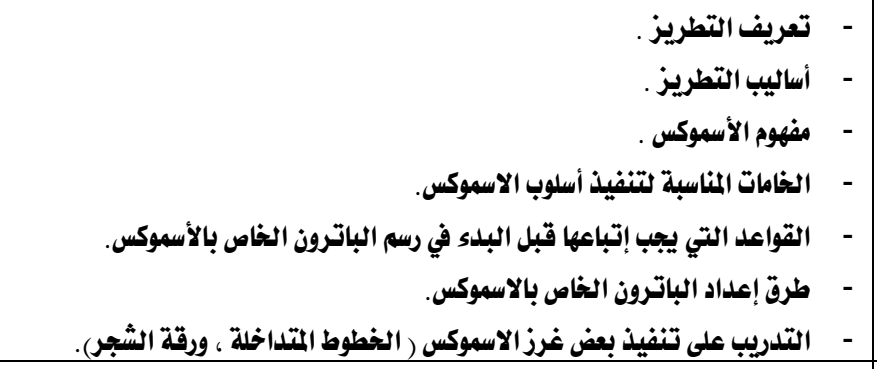 & الثالثة \\
\hline الرابع & 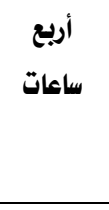 & 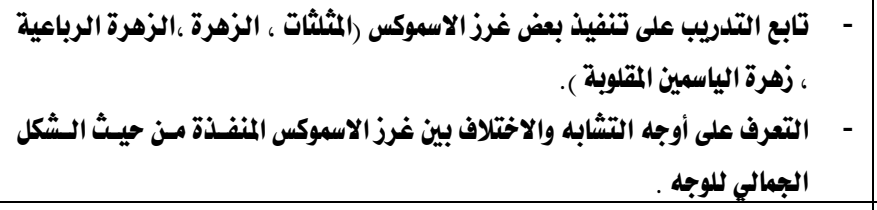 & الرابعة \\
\hline جامس & 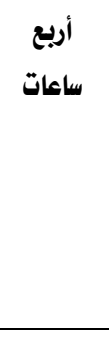 & ـ ـ ـعريف التطريز بالشرائط. . & الخامسة \\
\hline الخامس & 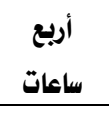 & 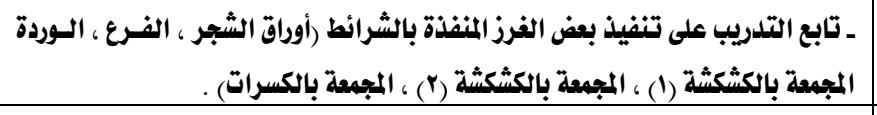 & السادسة \\
\hline السادس & 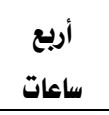 & ل ـ تابع التدريب على تنفيذ بعض الفرز المنفذة بالشرائط (الطائرة ، الزهـرة التويجيـة ، & السابعة \\
\hline (السادس & 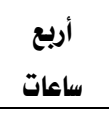 & 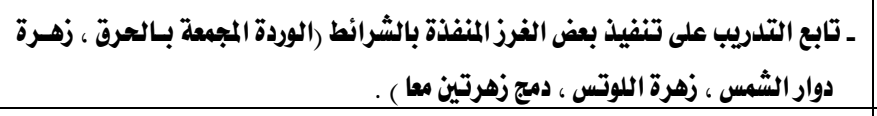 & الثامنة \\
\hline السابع & 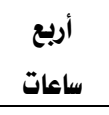 & ل & التاسعة \\
\hline الثامن & 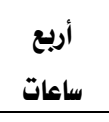 & 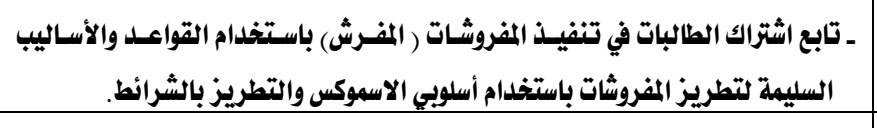 & العاشر \\
\hline التاسع & ساعات & 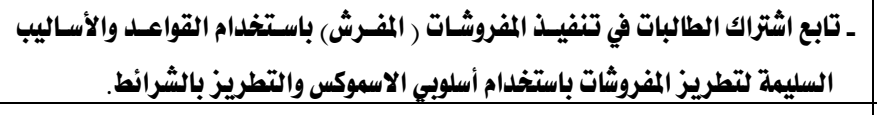 & عشادير \\
\hline العاشر & ساعات & 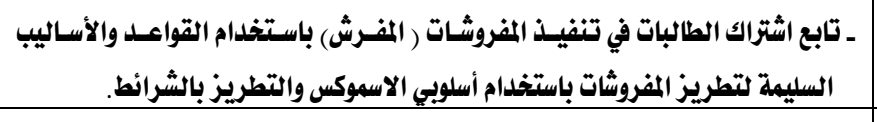 & 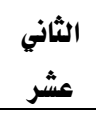 \\
\hline الحادي - مشر & 1 ساعات & 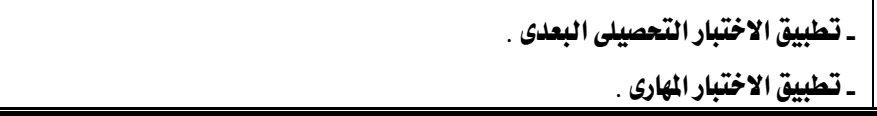 & عشر الثاث \\
\hline
\end{tabular}


ثالثا : الأساليب التدريبية للبرنامـج التدريبي :

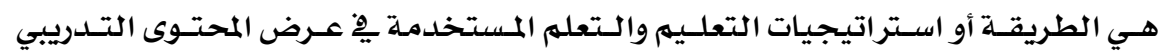

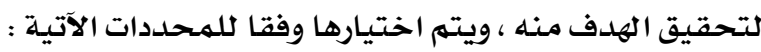

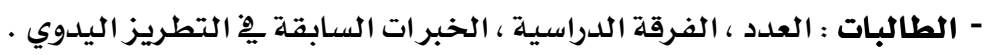

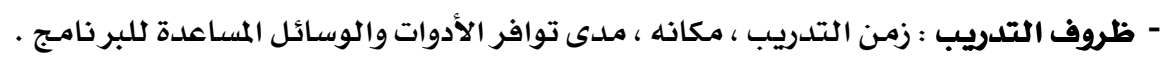

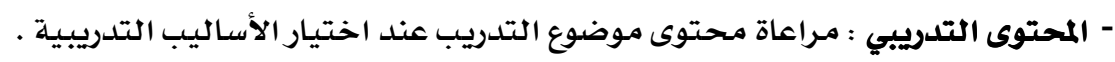

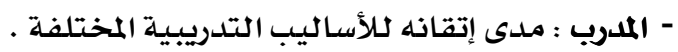

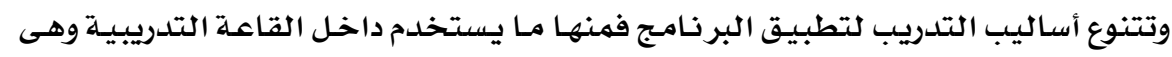

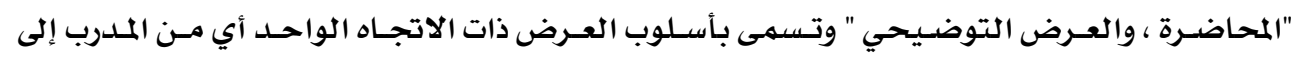

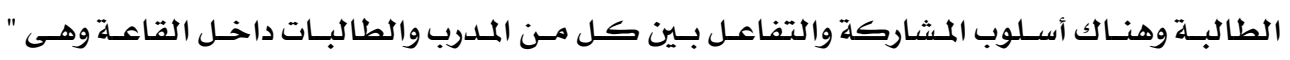

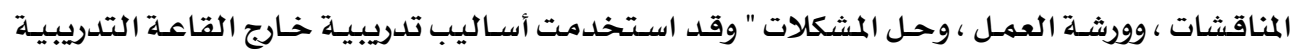

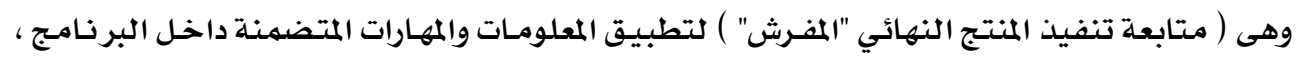

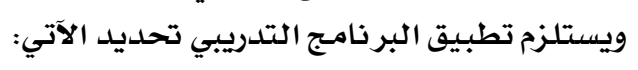

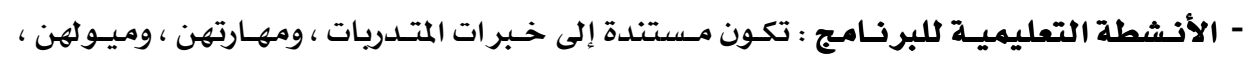

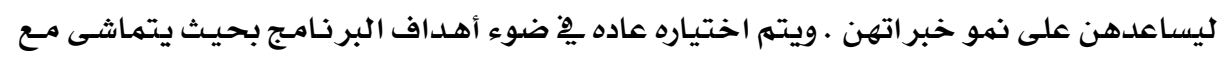

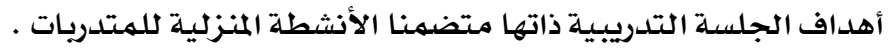

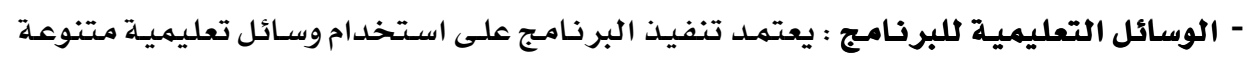

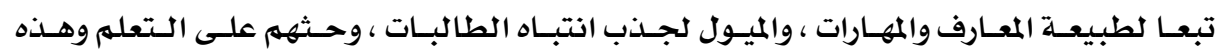
الوسائل هي : تبعائ

• عرض صور من مواقع الانترنت لتوضيح خطوات غرز التطريز محل الدراسة . • عرض فيديوهات من مواقع الانترنت لتوضيح خطوات غرز التطريز محل الدراسة . .

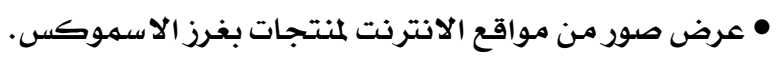
• عرض صور من مواقع الانترنت لمنتجات بغرز التطريز بالشرائط .

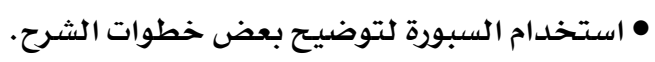
- الأدوات والخامات المستخدمة لإعداد البرنامج التدريبي : • الأدوات المستخدمة لتتفيذ الأسموكس. • الأدوات ( ابره شانيل، شمعه ، ولاعة ، ماسك ) المستخدمة الماتهة لتنفيذ التطريز بالشرائط .

$$
\text { • شرائط الساتان الدلازمة لتنفيذ التطريز بالشرائط. }
$$


رابعا : إعداد أدوات تقييم البرنامـج التدريبي :

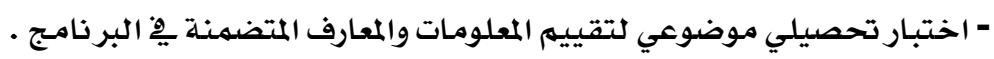

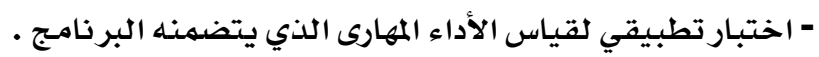

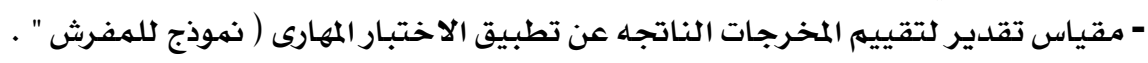

\section{ا- الاختبار التحصيلى الموضوعي المعربِ ملحق (r) :}

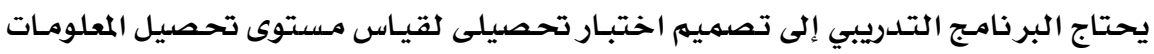

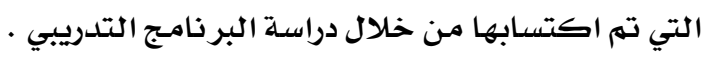

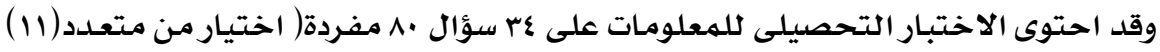

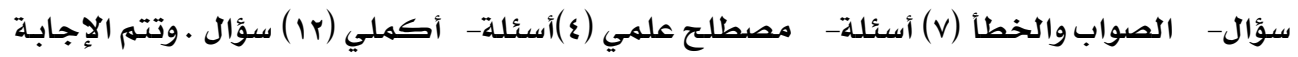
مِِّ نفس كراسة " نموذج الأسئلة".

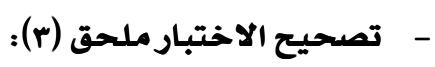

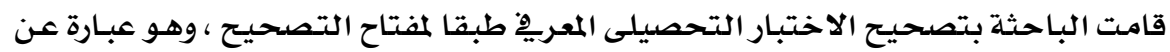

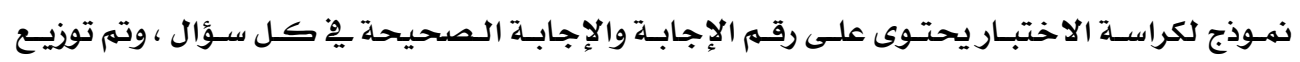

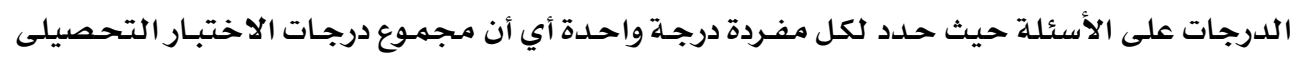
• 1 درجة .

\section{r- الاختبار التطبيقي المهارى ملحق (ع):}

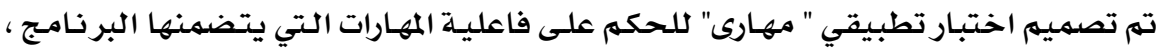

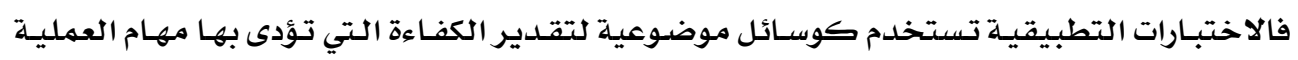
(الحسية الإدراكية ، الحركية ) وقد احتوى الاختبار التهبية التطبيقي على :

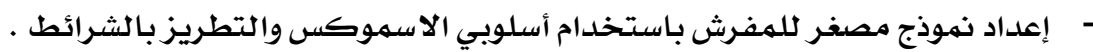

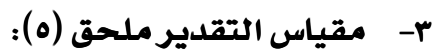

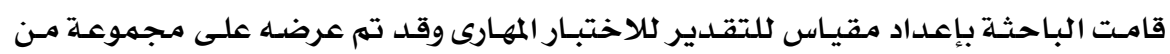

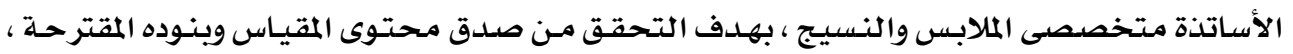

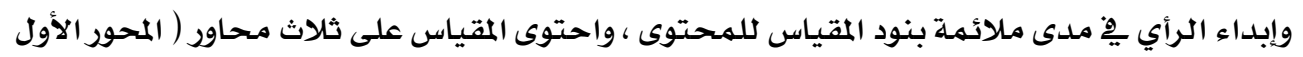

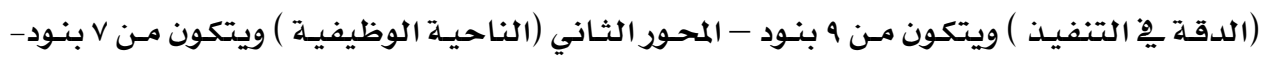

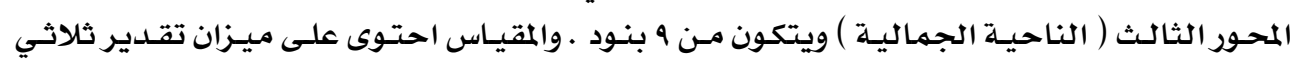

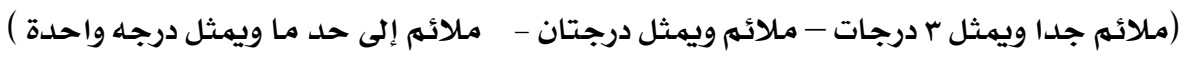

: التصحيح :

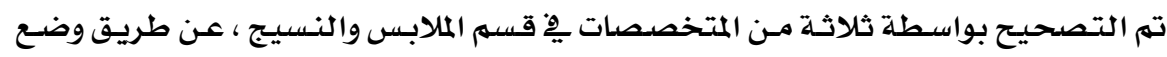

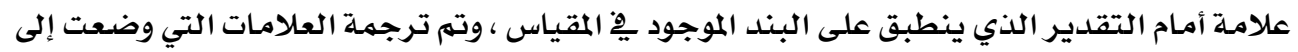

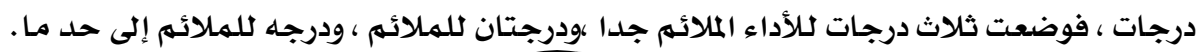


ع- استمارة تقييم المنتجات المنفذة (المفارش) من قبل المتخصصين ملحق (ج):

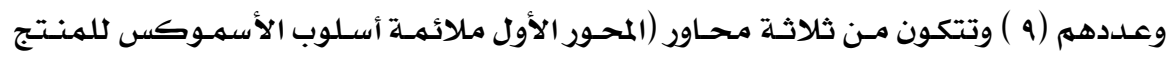

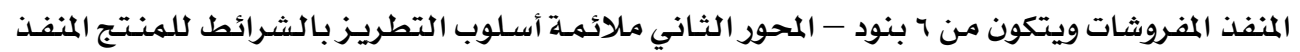

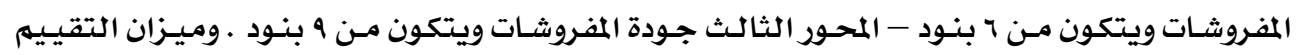

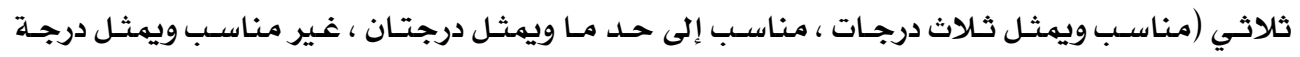
واحدة ).

\section{ه- استمارة تقييم المنتجات المنفذة (المفارث) من قبل المستهلكين ملحق (v):}

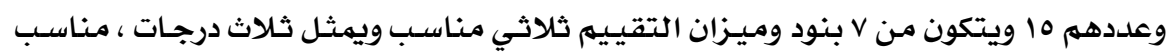

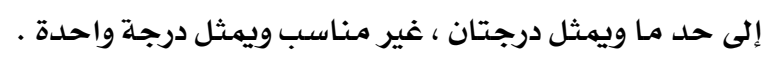

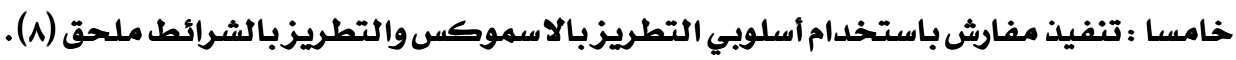

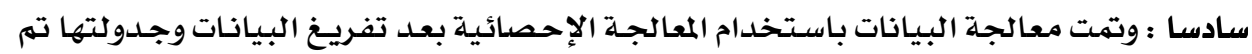

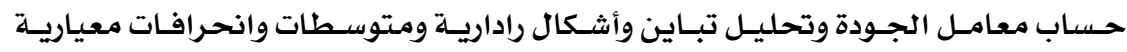

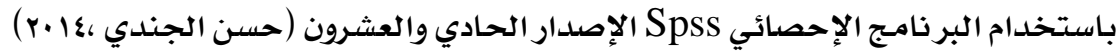

$$
\begin{aligned}
& \text { سابعا : صدق وثبات أدوات البحث : } \\
& \text { أولاً: الاختبار التحصيلي : ميلي } \\
& \text { ـ ـ حساب صدق الاتساق الداخلي: }
\end{aligned}
$$

تم التطبيق على عينة قوامها ( ـ ) من طالبات الفرقة الثالثة - شعبة اقتصاد منزبي بكلية

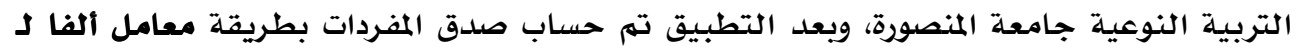

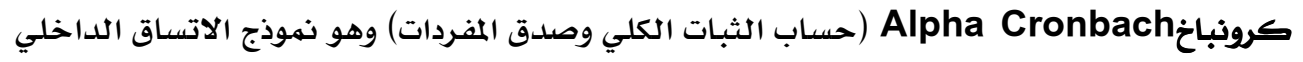

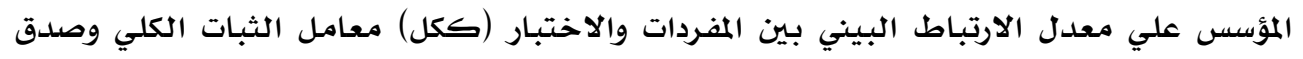

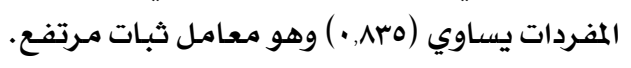

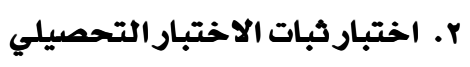

تم حساب ثبات الاختبار Reliability باستخدام التجزئة النصفية Split - Half ميثيات

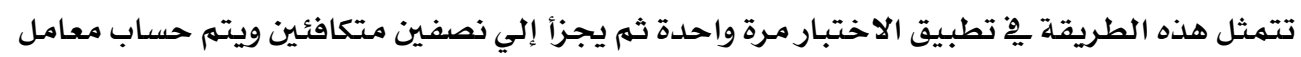

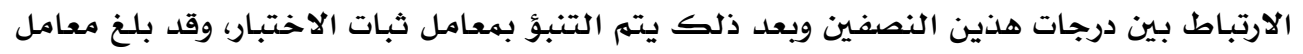

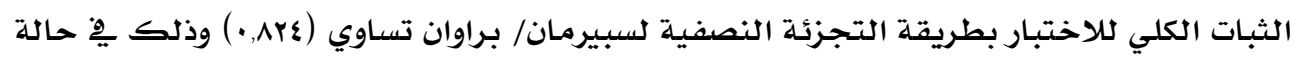

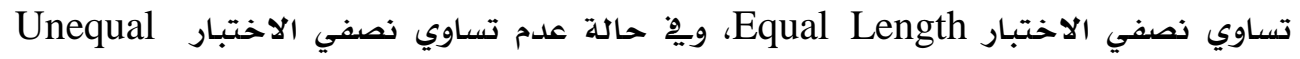

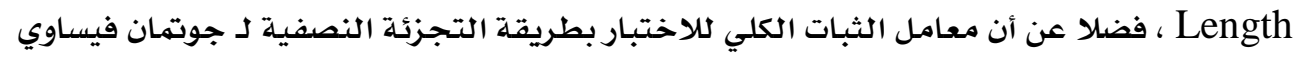

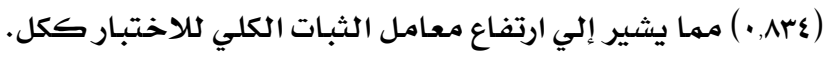




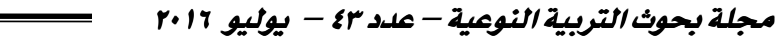

$$
\text { r. - مساب زمن الاختبار التحصيلي }
$$

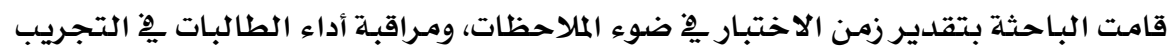

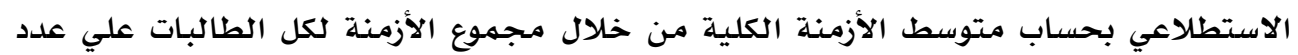
الطالبات، وقد بلغ زمس الاختبار ( . ب) دقيقة.

\section{\&. حساب معاملات السهولة والصعوبة لمفردات الاختبار التحصيلي}

تم حساب معاملات السهولة والصعوبة للاختبار ووجد أنها تراوحت ما بين ( بر. • و ایه,· )

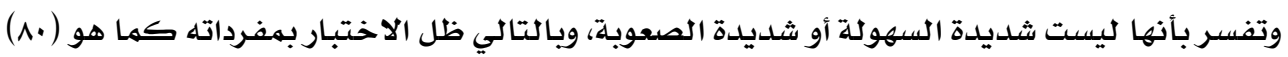
مفردة. ه. حساب معامل التمييز لمفردات الاختبار التحصيلي

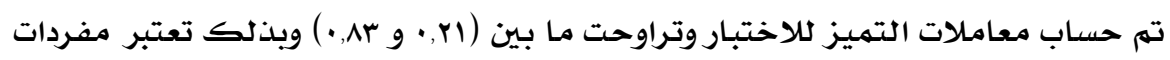
الاختبار ذات قدرة مناسبـة للتمييز.

\section{7. وضع الاختبار التحصيلي مِ الصورة النهائية للتطبيق}

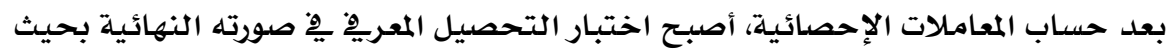

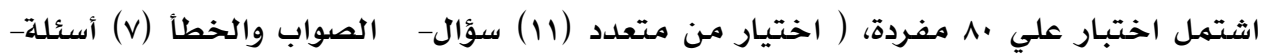

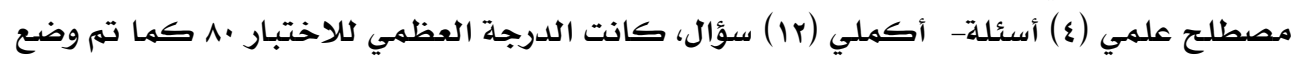

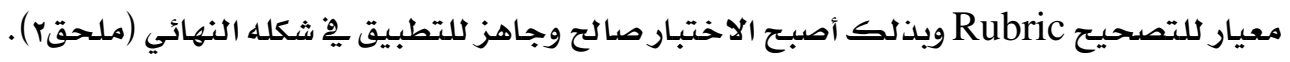
ثانياً: حساب الصلدق والثبات لمقياس تقدير الأداء المهاري ا ـ ـ حساب صدق الاتساق الداخلي:

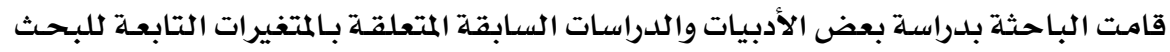

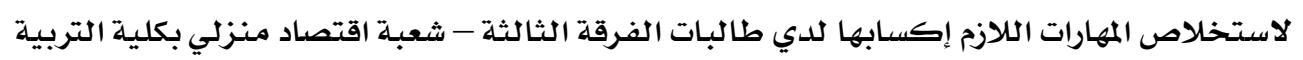

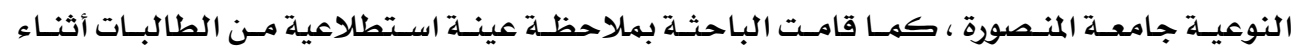

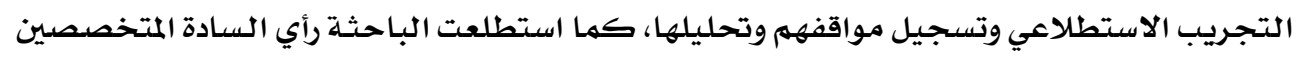

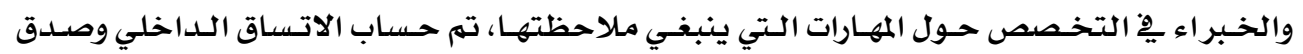

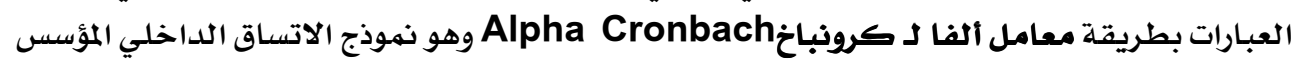

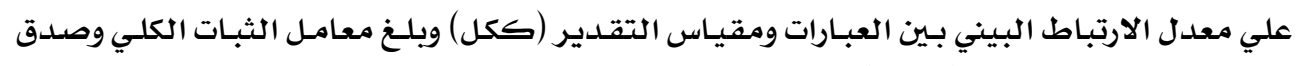

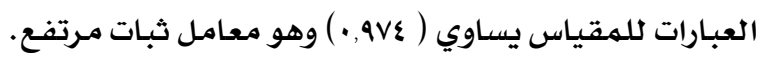
r اختبار ثبات لمقياس تقدير الأداء المهاري

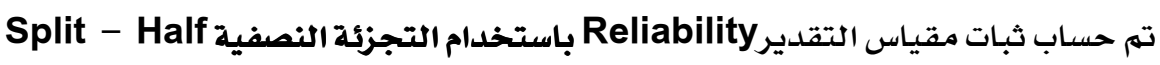

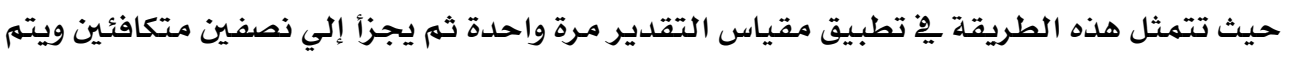

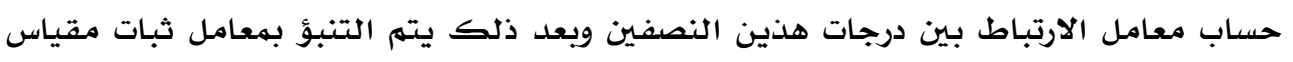

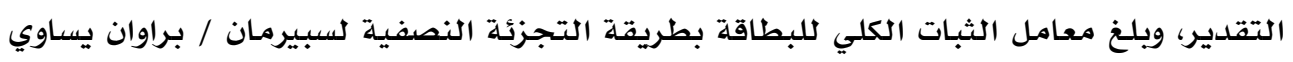




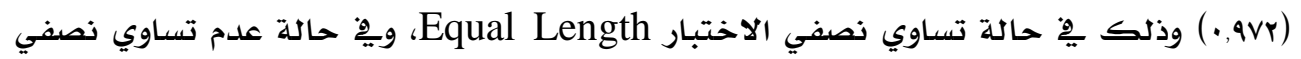

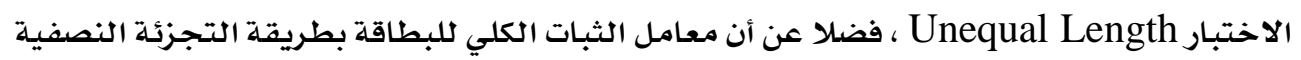

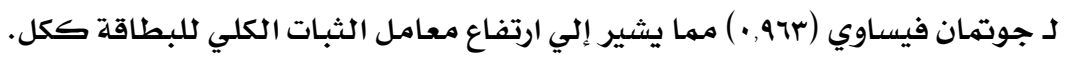
r. حساب زمن اختبار الأداء المهاري

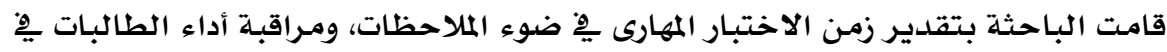

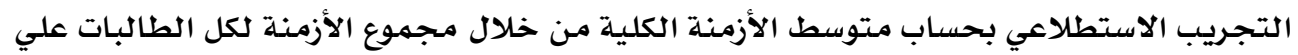
عدد الطالبات ، وقد بلـ زمن الاختبار ( ه ) سـاعات .

\section{ع. حساب معاملات السهولة والصعوبة لمفردات مقياس تقدير الأداء المهاري}

تم حساب معاملات السهولة والصعوبة للهقياس ووجد أنها تراوحت ما بين (19. • و V9,• )

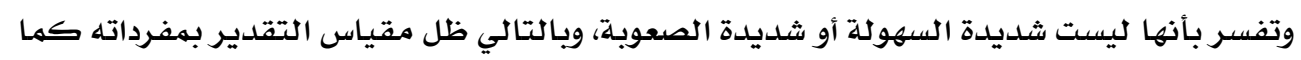

\section{حساب معامل التمييز لمفردات مقياس تقدير الأداء المهاري}

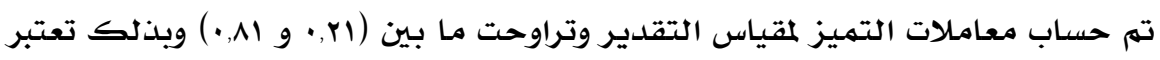
مفردات مقياس التقدير ذات قدرة مناسبة للتمييز.

\section{ه. وضع مقياس تقدير الأداء المهاري ِِ الصورة النهائية للتطبيق}

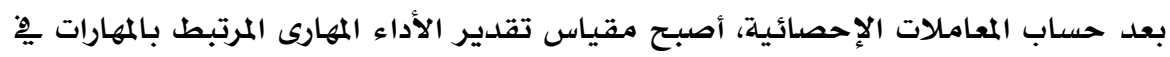

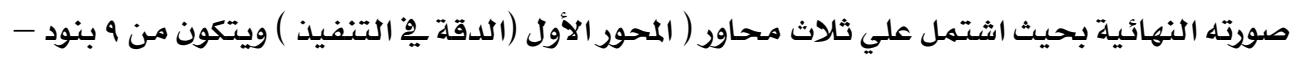

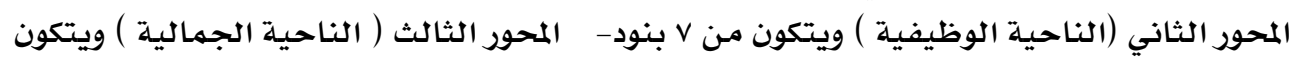

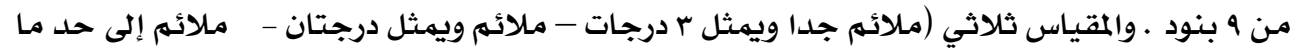

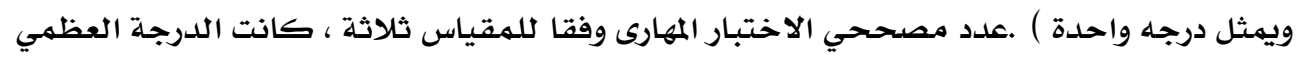

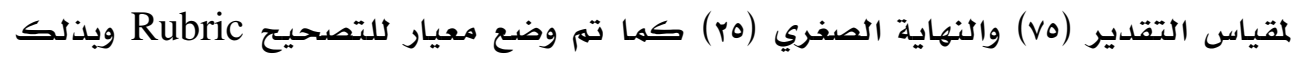

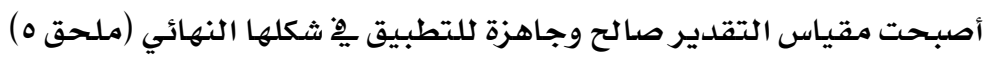
ثالثاً: استبييان تقبييم المحكمين المتخصصين للمنتجات المنفذة المقيرة قامت الباحثة بإعداد استبيان موجه للمتخصصين بمجال الملابس والنسيج - لتحكيم

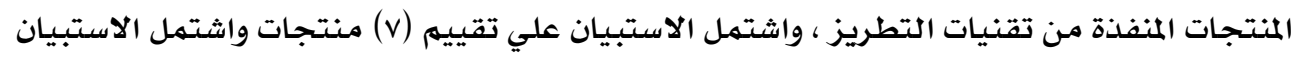
علي ثلاث محاور:

• المحور الأول: ملائمسة أسلوب الاسموكس للمنتج المنفذ (المفروشات) وتضمن (ج) عبارات. • المحور الثاني: ملائمة التطريز بالشرائط للمنتج المنفذ (المفروشات ) وتضمن (ج) عبارات.

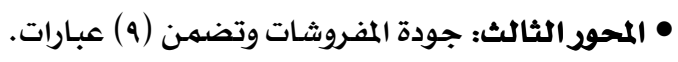


وقد استخدم ميزان تقدير ثلاثي المستويات بحيث تعطي الإجابة مناسب (ثلاث درجات)

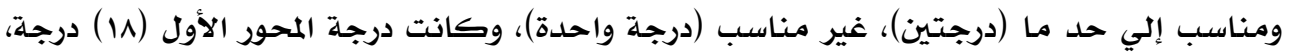

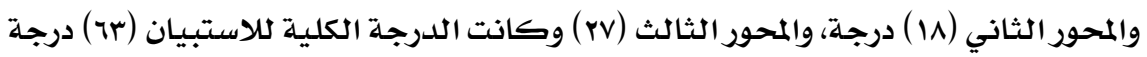

\section{صدق محتوي الاستبيان: صلدق المحكمين:}

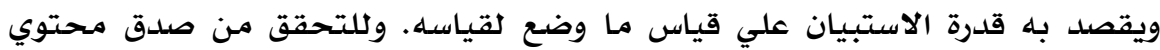

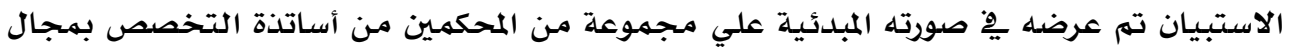

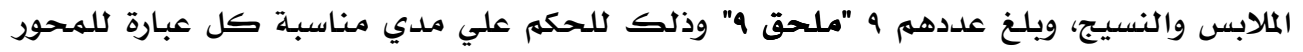

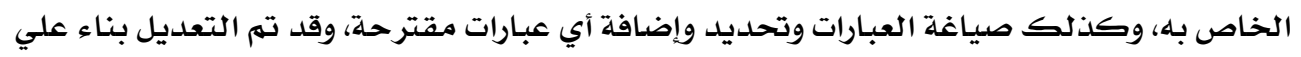

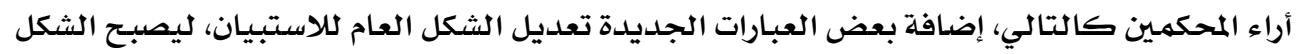

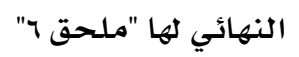

الصلدق باستخدام الاتساق الداخلي بين الدرجة الكلية لكل محوروالدرجة الكلية للاستبيان: تم حساب الصدق باستخدام الاتساق الداخلي وذلك بحساب معامل الارتباط (معامل

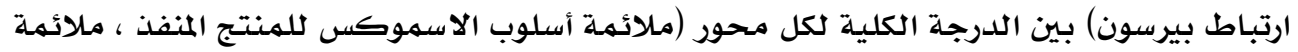

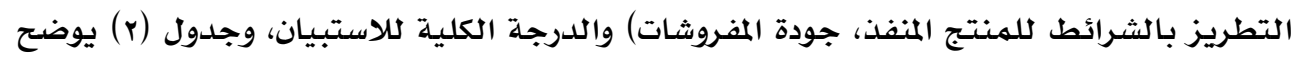
ذلك:

جدولr : قيم معاملات الارتباط بين درجة كل محور ودرجة الاستبيان

\begin{tabular}{|c|c|c|}
\hline 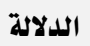 & الارتباط & \\
\hline$\cdot, \cdot 1$ & $\cdot, A r$ & المحور الأول: ملائمة أسلوب الاسموكس للمنتج المنفذ \\
\hline$\cdot, \cdot 1$ & $\cdot, 19$ & المحور الثاني: ملائمة التطريز بالشرائط للمنتج المنفذ \\
\hline$\cdot, \cdot 1$ & $\cdot, \wedge \xi$ & المحور الثالث: جودة المفروشات \\
\hline
\end{tabular}

يتضح من جدول (r) أن معاملات الارتباط كلها دالة عند مستوي ا.,. لاقترابها من

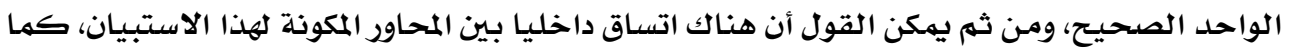

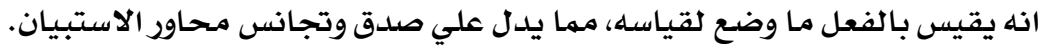
ثبات الاستبيان

يقصد بالثبات reability دقة الاختبار مِّ القياس والملاحظة، وعدم تناقضهل مـع نفسهه،

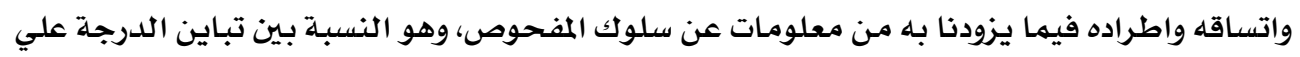

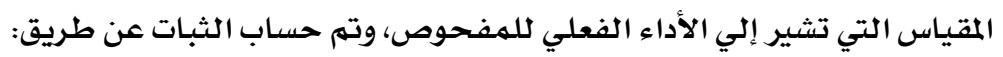

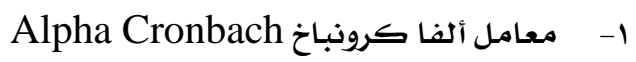

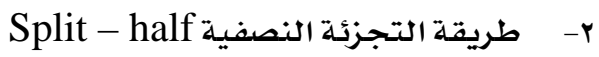


جدولr: قيم معامل الثبات لمحاور الاستبيان

\begin{tabular}{|c|c|c|}
\hline التجزئة النصفية & معامل ألذا & \\
\hline$\cdot, 9 r \cdot-\cdot, \wedge \varepsilon r$ & $\bullet, \wedge \leqslant 1$ & المحور الأول: ملائمة أسلوب الاسموكس للمنتج المنفذ \\
\hline •, Ar\&_, Arq & •, Arq & المحور الثاني: ملائمة التطريز بالشرائط للمنتج المنفذ \\
\hline$\bullet, ৭ \& 1-\bullet, \wedge \vee \neg$ & $\cdot, \wedge \vee 7$ & المحور الثالث: جودة المفروشات \\
\hline$\cdot, 9 \cdot 1-\cdot$, Arr & $\cdot, \Lambda Y I$ & ثبات الاستبيان ككل \\
\hline
\end{tabular}

يتضح من جلدول (r) أن جميع قيم معاملات الثبات، معامل ألفا، التجزئة النصفية، دالة

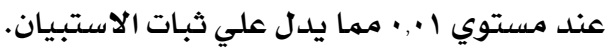
رابعاً: استمارة لتقييم المنتجات من قبل المستهلكين

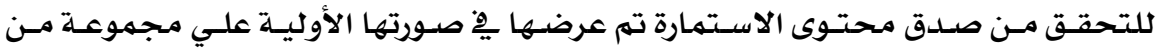

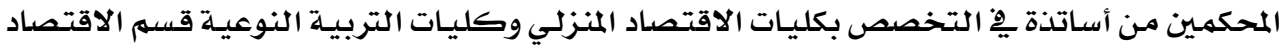

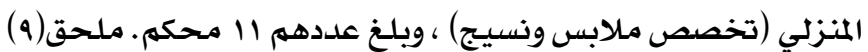
وذلك للحكم علي مدي مناسبة كل عبارة للمحور الخـاص بها وكذلك صياغة العبارات

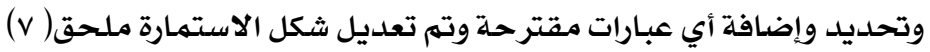
وتم حساب نسبة الاتفاق لدي المحكمين علي كل عبارة من عبارات الاستبيان ، وتم استبعاد

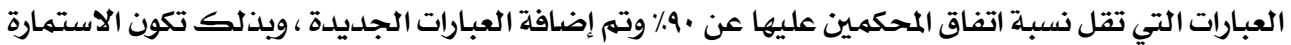

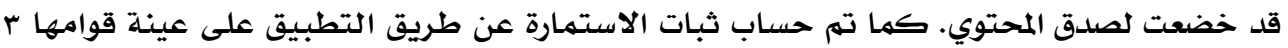
منتجات تتوافر فيها نفس شروط عينة الدراسة وبعد التطبيق تم حساب الثبات بطريقة التجزئة

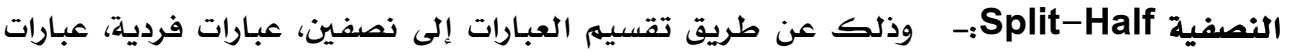
زوجية وقد تم هذا التقسيه بالنسبة للعبارات ككل. لحساب الارتباط بين نصفي بنود الاستمارة .

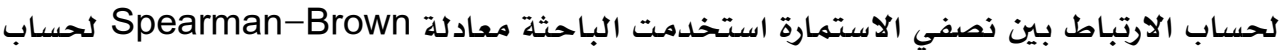

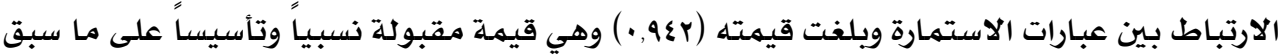

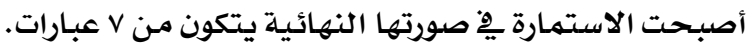
مناقشة النتائج التي توصل إليها البحث:

$$
\text { • الفرض الأول }
$$

للتحقق من صحة الفرض الأول من فروض البحث والذي ينص علي: " يوجد فرق دال

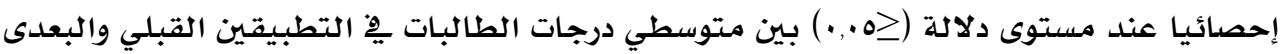

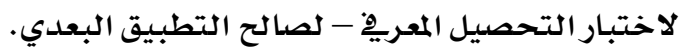


ولاختبار صحة هذا الفرض تم حساب (t-test لمتوسطين مرتبطين) للمقارنة بين متوسطي

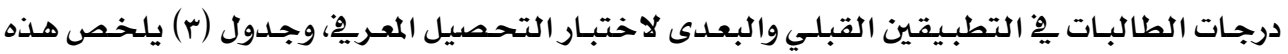
النتائج.

جدول (r) يوضح نتائج اختبار "ت" للمقارنة بين درجات الطالبات يِ التطبيقين القبلي والبعدى لاختبار

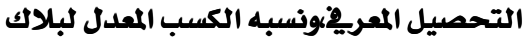

\begin{tabular}{|c|c|c|c|c|c|c|c|c|c|}
\hline معدل الكسب|| & توة دلأثلة & التأثير & ربع إيتا & مستوي الدلالة & "قيمة & الحرجة & الالمعياري & المتوسط & لتطبيق \\
\hline |وهي 1.95 & & \multirow{2}{*}{19.89} & \multirow{2}{*}{0.99} & \multirow{2}{*}{ دال } & \multirow{2}{*}{$\begin{array}{c}328 . \\
70\end{array}$} & \multirow{2}{*}{21} & .88 & .72 & القبلي \\
\hline قيمة مقبولة | & & & & & & & 1.01 & 78.50 & البعدي \\
\hline
\end{tabular}

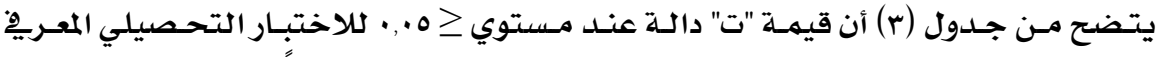

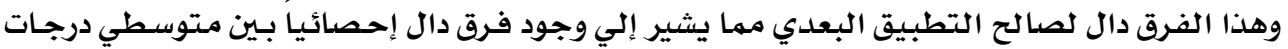

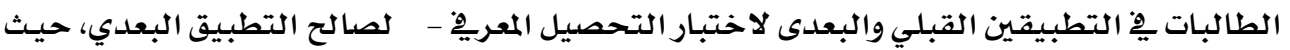

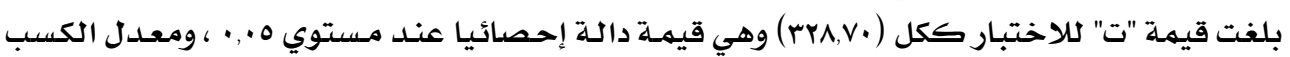

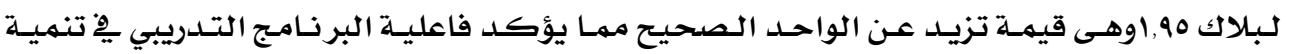

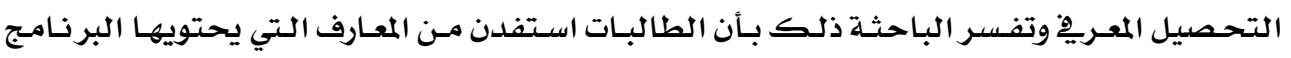

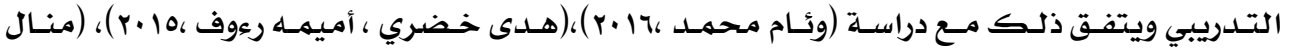

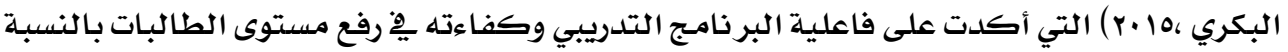

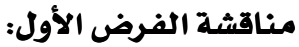

تم قبول الفرض الأول من فروض البحث والذي ينص علـي : يوجد فرق دال إحصائيا عند

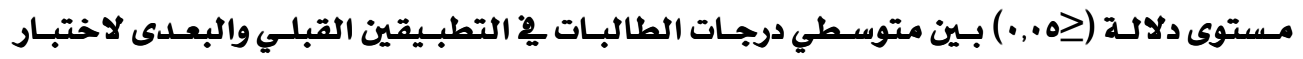

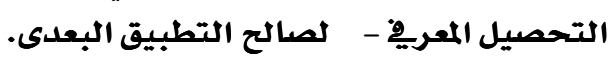

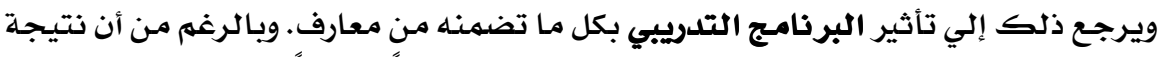

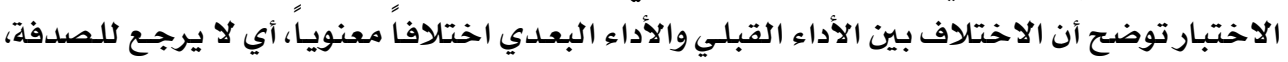

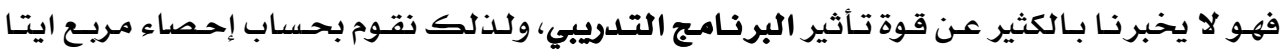
لحساب حجم التأثير ويهكن حسابه من المعادلة التالية:

$$
\eta^{2}=\frac{t 2}{t 2+(N-1)}
$$

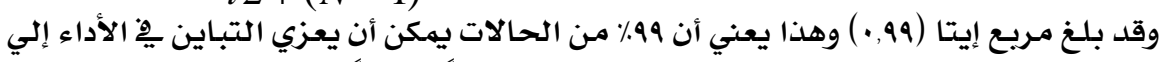

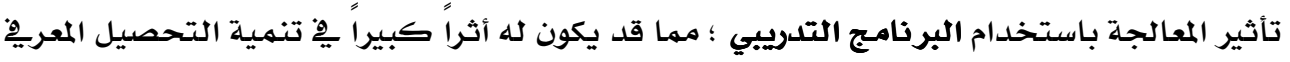

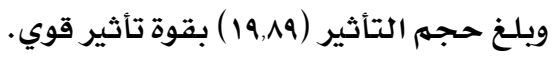




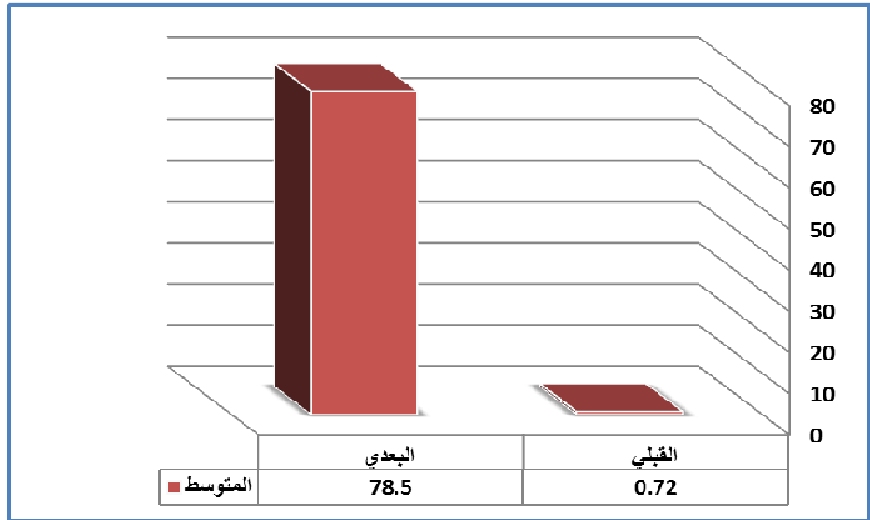

شكل (1) متوسط درجات الطالبات فى التطبيقين القبلي والبعدى لاختبار التحصيل المعريٍ

ثانياً: تتائج مقياس تتقدير الأداء المهاري • الفرض الثاني

للتحقق من صحة الفرض الثاني من فروض البحث والذي ينص علي: " يوجد فرق دال

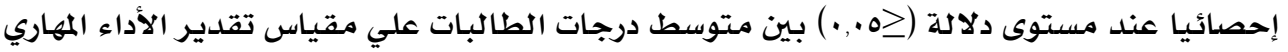

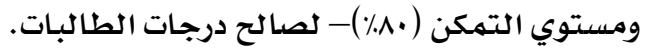

ولاختبار صحة هذا الفرض تم حساب (t-test لمتوسطين مرتبطين) للمقارنة بين متوسطي

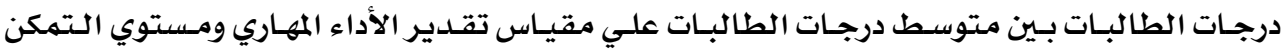

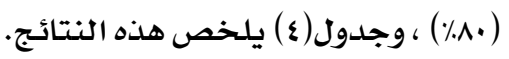
جدول (§) يوضح نتائج اختبار "ت" للمقارنة بين متوسط درجات الطالبات علي مقياس تقدير الأداء المهاري

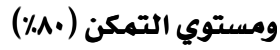

\begin{tabular}{|c|c|c|c|c|c|c|}
\hline ق ق قوة دلالة التأثير & حجم التأثير & 2|مربع إيتا & الدلالة & قيمة "ت" & الانحراف المعياري درجة الحرية & المتوسط \\
\hline قوي & 3.20 & 0.72 & 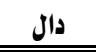 & 7.39 & 6.399 & 70.09 \\
\hline
\end{tabular}

يتضح من جدول (ع) أن قيمة "ت" دالة عند مستوي \ ه.., · علي مقياس تقدير الأداء

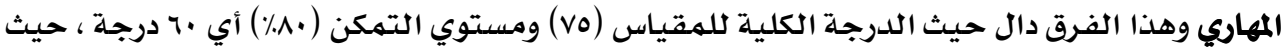

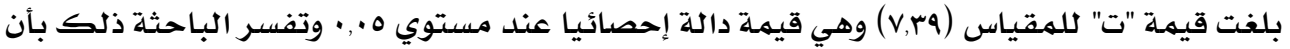

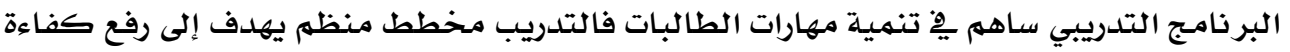

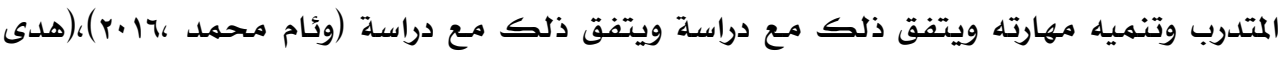

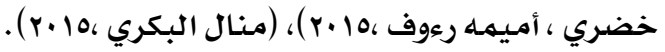




$$
\text { مناقشة الفرض الثاني: }
$$

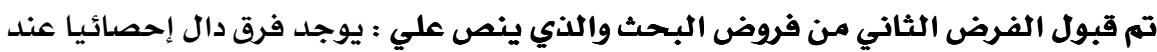

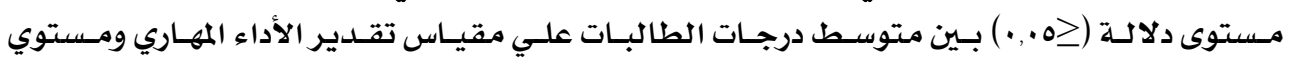
التمكن (•^^) - لصالح درجات الطالبات.

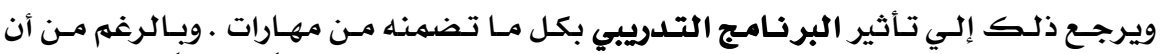

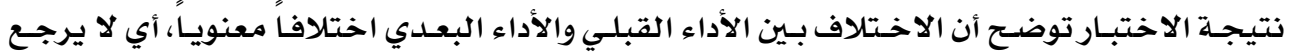

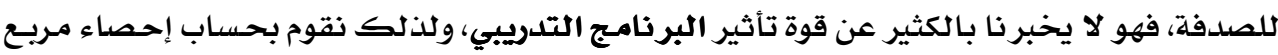

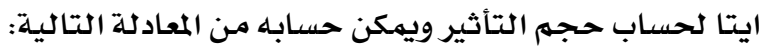

$$
\eta^{2}=\frac{t 2}{t 2+(N-1)}
$$

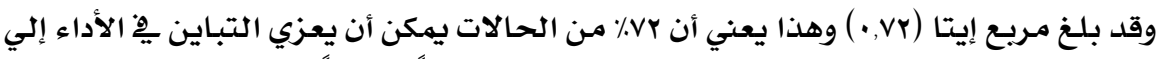

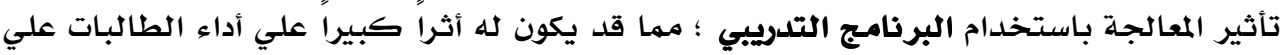

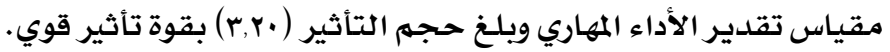

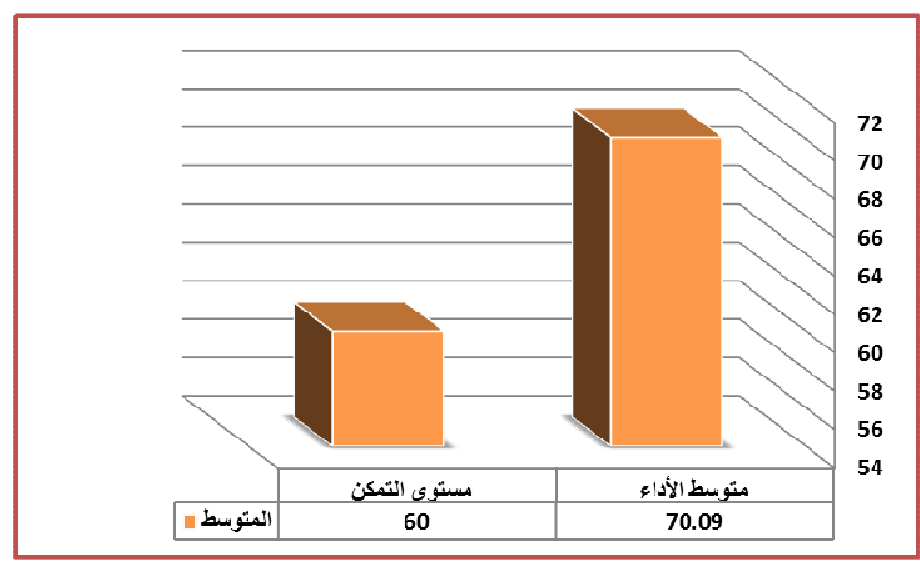

شكل (Y) متوسط درجات الطالبات علي مقياس تقدير الأداء المهاري ومستوي التمكن (•A٪) ثاثثً: تتائج استمارة تقييم المحكمين للمنتجات المنفذة مئوسئ

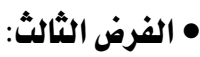

توجد فروق ذات دلالة إحصائية بين المنتجات المنفذة يِ ملائمة أسلوب الاسموكس للمنتج

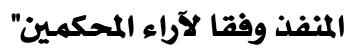

وللتحقق من هذا الفرض تم حساب تحليل التباين لمتوسط درجات المنتجات المنفذة فِواء

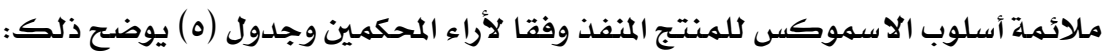




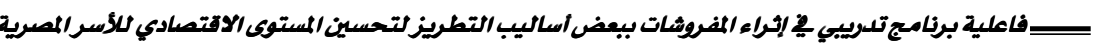

جدوله : تحليل التباين لمتوسط درجات المنتجات المنفذة يْ ملائمة أسلوب الاسموكس

للمنتج المنفذ وفقا لأراء المحكمين

\begin{tabular}{||lcccc||}
\hline \hline & \\
\hline
\end{tabular}

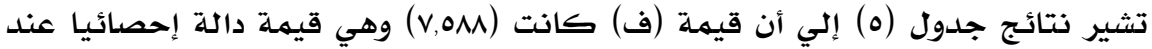

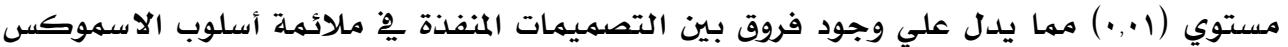
للمنتج المنفذ وفقا لأراء المحكمـين. وتم حسـاب المتوسطات والانحرافات المعيارية ومعامل جودة

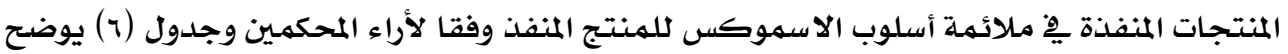
ذلك.

جدولج: المتوسطات والانحرافات المعيارية ومعامل الجودة لدرجات المنتجات المنفذة ـِّ تحقيق ملائمة أسلوب الاسموكس للمنتج المنفذ وفقا لأراء المحكمين

\begin{tabular}{|c|c|c|c|}
\hline معامل الجودة & الانحراف المعياري & المتوسط & التصميي \\
\hline 100.00 & 0.00 & 27.00 & المنتج | \\
\hline 95.06 & 0.82 & 25.67 & الميتتج r \\
\hline 100.00 & 0.00 & 27.00 & المنتج r \\
\hline 98.77 & 0.52 & 26.67 & المنتج ؛ \\
\hline 100.00 & 0.00 & 27.00 & المنتج ه \\
\hline 99.38 & 0.41 & 26.83 & المنتج 7 \\
\hline 99.38 & 0.41 & 26.83 & v المنتج v \\
\hline
\end{tabular}




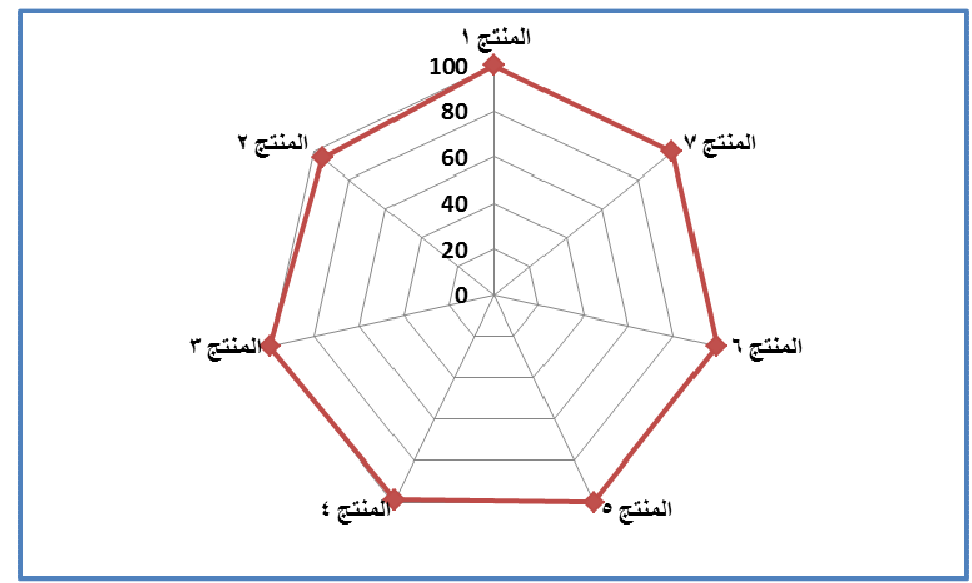

شكل (r) يوضح معامل الجودة لدرجات المنتجات المنفذة يف تحقيق ملائمة أسلوب الاسموكس للمنتج المنفذ وفقا لأراء المحكمين.

$$
\text { من الجدول (ج) والشكل (r) يتضح أن: }
$$

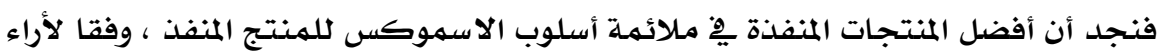

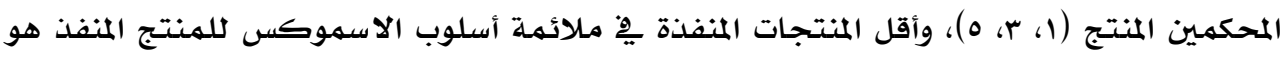

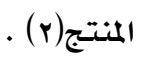

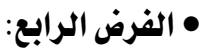

توجد فروق ذات دلالة إحصائية بين المنتجات المنفذة يْ تحقيق ملائمة التطريز بالشرائط

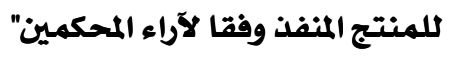

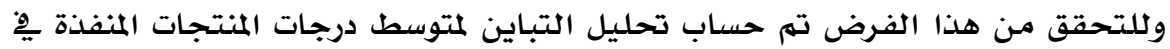

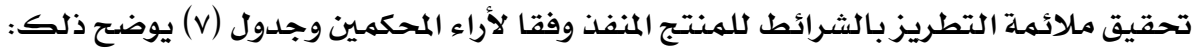
جدولV: تحليل التباين لمتوسط درجات المنتجات المنفذة يِّ تحقيق ملائمة التطريز بالشرائط للمنتج المنفذ وفقا لأراء المحكمين

\begin{tabular}{|c|c|c|c|c|c|}
\hline الدلالة & قيمة "ف" & متوسط المربعات & درجة الحرية & مجموع المربعات & الناحية الجمالية \\
\hline \multirow{3}{*}{.007} & \multirow{3}{*}{3.611} & 4.437 & 6 & 26.619 & بين المجموعات \\
\hline & & 1.229 & 35 & 43.000 & داخل المجموعات \\
\hline & & & 41 & 69.619 & المجموع \\
\hline
\end{tabular}

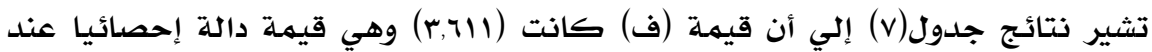

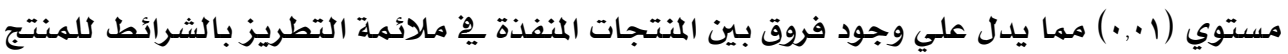




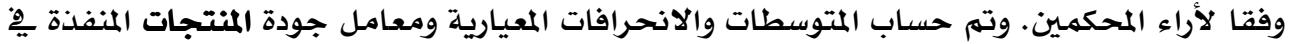

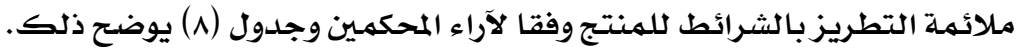
جدولم: المتوسطات والانحرافات المعيارية ومعامل الجودة لدرجات المنتجات المنفذة فِ ملائمة التطريز بالشرائط للمنتج وفقا لأراء المحكمين

\begin{tabular}{|c|c|c|c|}
\hline معامل الجودة & الانحراف المعياري & المتوسط & التصميي \\
\hline 97.53 & 1.03 & 26.33 & |المنتج 1 \\
\hline 90.12 & 1.51 & 24.33 & المنتج r \\
\hline 97.53 & 1.03 & 26.33 & المنتج r \\
\hline 96.30 & 1.10 & 26.00 & المنتج ؛ \\
\hline 99.38 & 0.41 & 26.83 & المنتج 0 \\
\hline 97.53 & 0.82 & 26.33 & المنتج 1 \\
\hline 93.21 & 1.47 & 25.17 & المنتج v \\
\hline
\end{tabular}

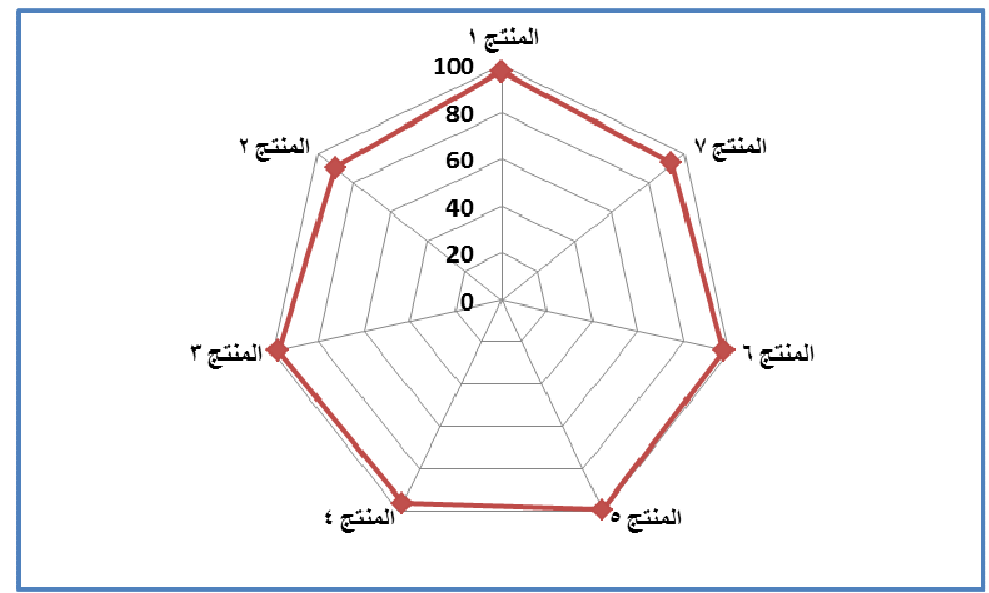

شكل (ع) يوضح معامل الجودة لدرجات المنتجات المنفذة يْ ملائمة التطريز بالشرائط للمنتج وفقا لأراء المحكمين.

$$
\text { من الجدول (^) والشكل (ع ) يتضح أن: }
$$

فنجد أن أفضل المنتجات المنفذة يِّ ملائمسة التطريز بالشرائط للمنتج ، وفقا لأراء المحكمين

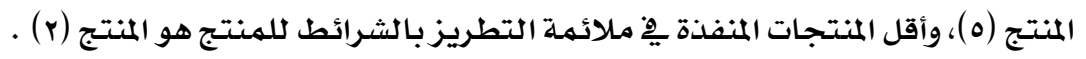




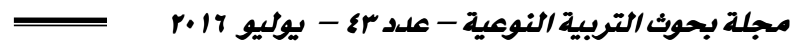

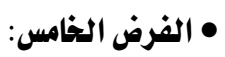

توجد فروق ذات دلالة إحصائية بين التصميمات المنفذة ـِ تحقيق جودة المفروشات وفقا لآراء المحكمين" توجين

وللتحقق من هذا الفرض تم حساب تحليل التباين لمتوسط درجات التصميمات المنفذة ِِِ

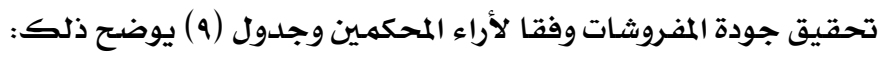

جدوله: تحليل التباين لمتوسط درجات المنتجات المنفذة فِ تحقيق جودة المفروشات وفقا لأراء المحكمين دروات

\begin{tabular}{|c|c|c|c|c|c|}
\hline الدلالة & قيهة "ف" & متوسط المربعات & درجة الحرية & مجموع المربعات & الناحية الوظيفية \\
\hline \multirow{3}{*}{.000} & \multirow{3}{*}{4.840} & 4.571 & 6 & 27.429 & بين المجموعات \\
\hline & & .944 & 56 & 52.889 & داخل المجموعات \\
\hline & & & 62 & 80.317 & المجموع \\
\hline
\end{tabular}

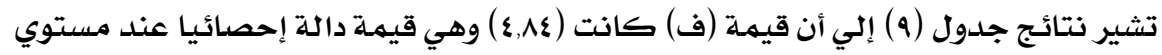

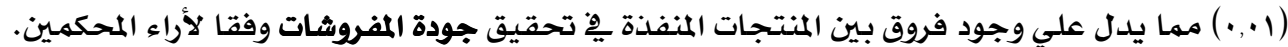

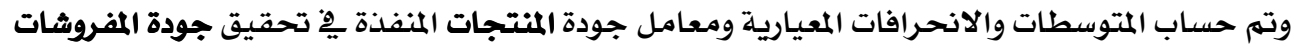

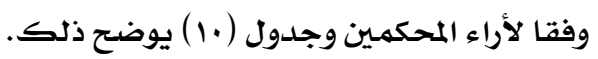

جدول • 1 : المتوسطات والانحرافات المعيارية ومعامل الجودة لدرجات المنتجات المنفذة مُ تحقيق جودة المفروشات وفقا لأراء المحكمين

\begin{tabular}{|c|c|c|c|}
\hline معامل الجودة & الانحراف المعياري & المتوسط & التصميي \\
\hline 98.35 & 1.33 & 26.56 & المنتج | \\
\hline 92.18 & 1.45 & 24.89 & المنتج r \\
\hline 100.00 & 0.00 & 27.00 & المنتج r \\
\hline 97.53 & 1.00 & 26.33 & المنتج ؛ \\
\hline 100.00 & 0.00 & 27.00 & المنتج ه \\
\hline 97.94 & 0.88 & 26.44 & المنتج 1 \\
\hline 97.12 & 0.97 & 26.22 & المتتج v \\
\hline
\end{tabular}




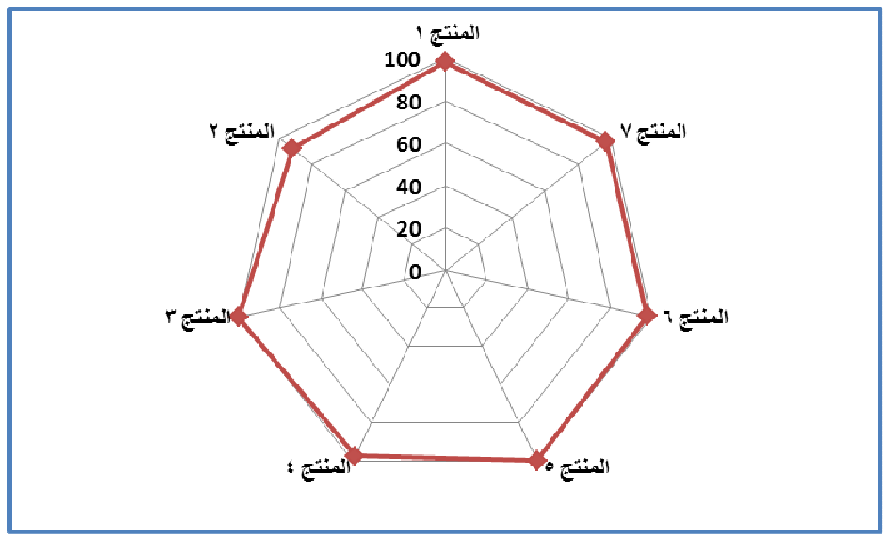

شكل (0) يوضح معامل الجودة لدرجات المنتجات المنفذة يِ تحقيق جودة المفروشات وفقا لأراء المحكمين.

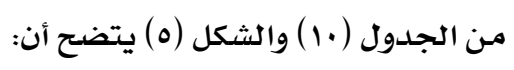

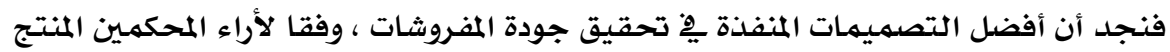

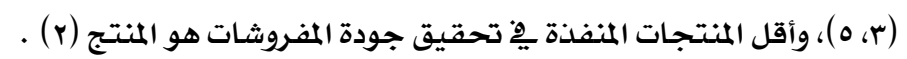

$$
\text { • • الفرض السادس: }
$$

توجد فروق ذات دلالة إحصائية بين محاور تقييم المنتجات المنفذة وفقا لآراء المحكمين "

وللتحقق من هذا الفرض تم حساب تحليل التباين لمتوسط درجات محاور تقييم المنتجات

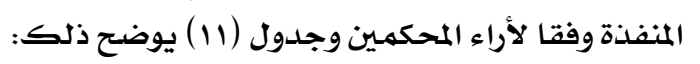

\begin{tabular}{|c|c|c|c|c|c|}
\hline الدلالة & قيمة "ف" & متوسط المربعات & درجة الحرية & مجموع المربعات & المجموع \\
\hline \multirow{3}{*}{.003} & \multirow{3}{*}{6.048} & 6.909 & 2 & 13.819 & بين المجموعات \\
\hline & & 1.142 & 144 & 164.508 & داخل المجموعات \\
\hline & & & 146 & 178.327 & المجموع \\
\hline
\end{tabular}

جدول|/1: تحليل التباين لمتوسط درجات المنتجات المنفذة وفقا لأراء المحكمين

تشير نتائج جدول (11) إلي أن قيمـة (ف) كانت (ع.,7) وهي قيمة دالة إحصائيا عند

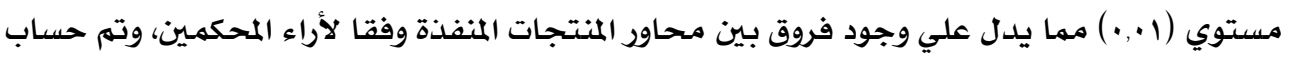

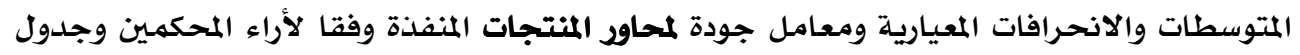
(r) ( ا ) يوضتح ذلك. 


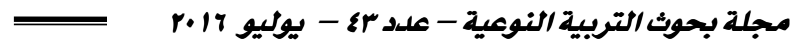

جدول 1 : المتوسطات والانحرافات المعيارية ومعامل الجودة لدرجات محاور المنتجات المنفذة وفقا لأراء المحكمين

\begin{tabular}{|c|c|c|c|}
\hline معامل الجودة & الانحراف المعياري & المتوسط & 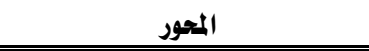 \\
\hline 98.94 & 0.60 & 26.71 & ملائمة أسلوب الاسموكس للمنتج المنفذ \\
\hline 95.94 & 1.30 & 25.90 & ملائمة التطريز بالشرائط للمنتج \\
\hline 97.59 & 1.14 & 26.35 & جودة المفروشات \\
\hline
\end{tabular}

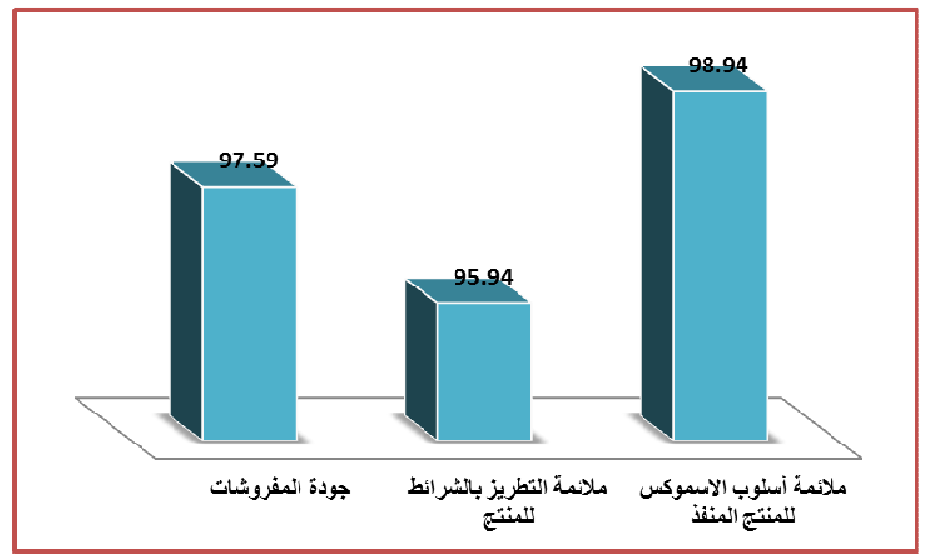

شكل (7) يوضح معامل الجودة لمحاور المنتجات المنفذة وفقا لأراء المحكمين.

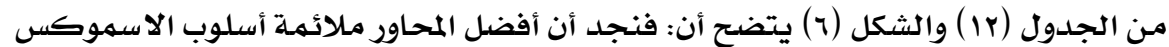

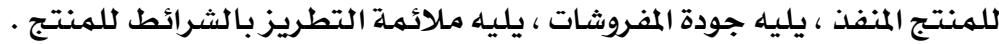

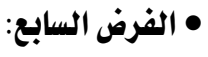

توجد فروق ذات دلالة إحصائية بين المنتجات المنفذة وفقا لآراء المحكمين "

وللتحقق من هذا الفرض تم حساب تحليل التباين لمتوسط درجات المنتجات المنفذة وفقا

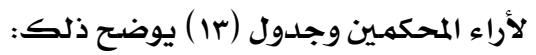

جدولrا : تحليل التباين لمتوسط درجات المنتجات المنفذة وفقا لأراء المحكمين

\begin{tabular}{|c|c|c|c|c|c|}
\hline الدلالة & قيمة "ف" & متوسط المربعات & درجة الحرية & مجموع المربعات & المجموع \\
\hline \multirow{3}{*}{.000} & \multirow{3}{*}{10.826} & 9.420 & 6 & 56.517 & بين المجموعات \\
\hline & & .870 & 140 & 121.810 & داخل المجموعات \\
\hline & & & 146 & 178.327 & المجموع \\
\hline
\end{tabular}

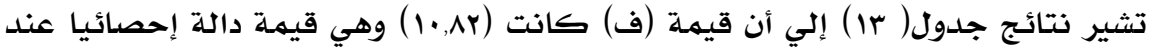

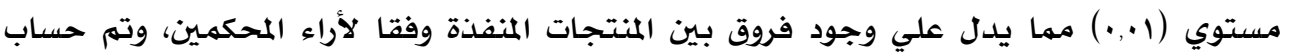




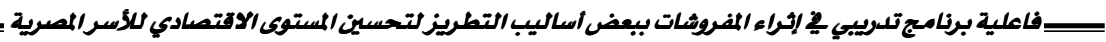

المتوسطات والانحرافات المعيارية ومعامل جودة المنتجات المنفذة يِّ تحقيق النواحي (ككل) وفقا لأراء المحكمين وجدول ( \& ا ) يوضتح ذلك.

جدول| ا : المتوسطات والانحرافات المعيارية ومعامل الجودة لدرجات المنتجات المنفذة وفقا لأراء المحكمين

\begin{tabular}{|c|c|c|c|c|}
\hline الترتيب & معامل الجودة & الانحراف الميعياري & المتوسط & التصميم \\
\hline 3 & 98.59 & 1.02 & 26.62 & المنتج \\
\hline 7 & 92.42 & 1.36 & 24.95 & المنتج r \\
\hline 2 & 99.29 & 0.60 & 26.81 & المنتج r \\
\hline 5 & 97.53 & 0.91 & 26.33 & المنتج ؛ \\
\hline 1 & 99.82 & 0.22 & 26.95 & المتتج ه \\
\hline 4 & 98.24 & 0.75 & 26.52 & المنتج 9 \\
\hline 6 & 96.65 & 1.18 & 26.10 & المنتج V \\
\hline
\end{tabular}

شكل (v) يوضح معامل الجودة لدرجات المنتجات المنفذة وفقا لأراء المحكمين.

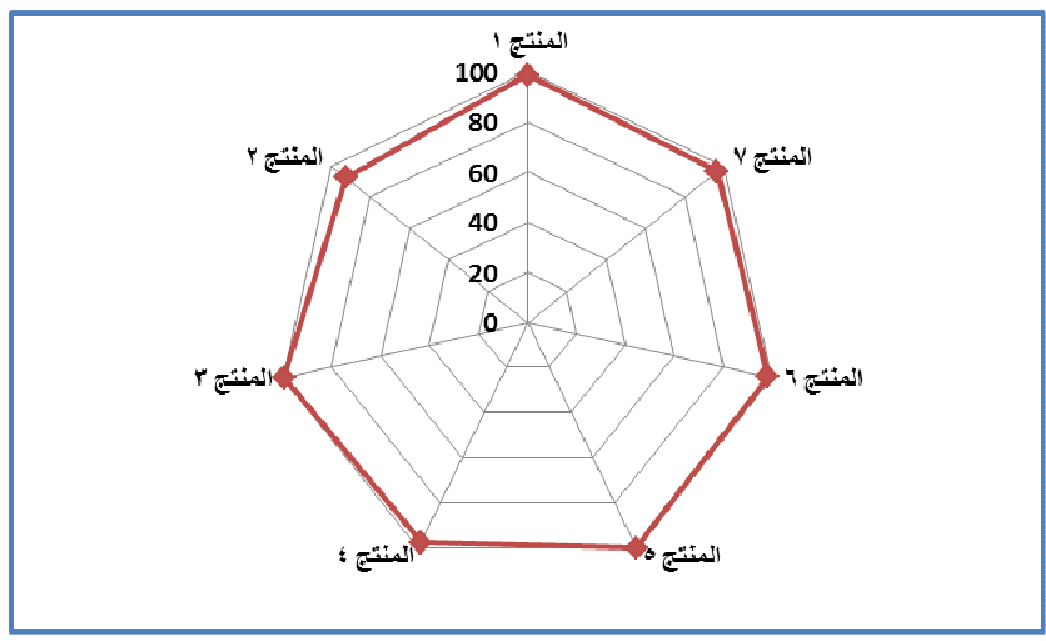

من الجدول (乏) أ والشكل (v) يتضع أن:

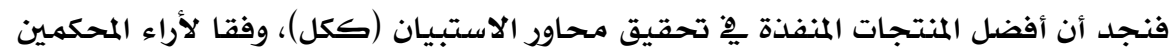

المنتج (ه)، وأقل المنتجات المنفذة هو المنتج (r) . 


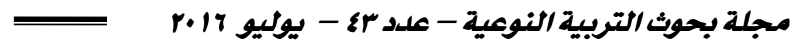

رابعاً: تتائج تقييي المنتجات من قبل المستهلكين

• الفرض الثامن:

توجد فروق ذات دلالة إحصائية بين المنتجات المنفذة وفقا لآراء المستهلكين "

وللتحقق من هذا الفرض تم حساب تحليل التباين لمتوسط درجات المنتجات المنفذة وفقا

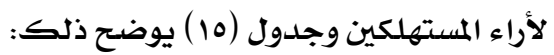

جدول10 : تحليل التباين لمتوسط درجات المنتجات المنفذة وفقا لأراء المستهلكين

\begin{tabular}{|c|c|c|c|c|c|}
\hline الدلالة & قيمة "ف" & متوسط المربعات & درجة الحرية & مجموع المربعات & المجموع \\
\hline \multirow{3}{*}{.000} & \multirow{3}{*}{9.672} & 17.041 & 6 & 102.245 & بين المجموعات \\
\hline & & 1.762 & 42 & 74.000 & داخل المجموعات \\
\hline & & & 48 & 176.245 & المجموع \\
\hline
\end{tabular}

تشير نتائج جدول (10) إلي أن قيمة (ف) كانت (9,TV) وهي قيممة دالة إحصائيا عند

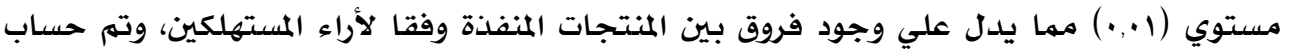

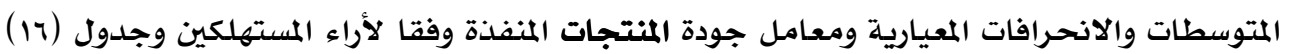

يوضسح ذلك.

جدول17 : المتوسطات والانحرافات المعيارية ومعامل الجودة لدرجات المنتجات المنفذة وفقا لأراء المستهلكين

\begin{tabular}{|c|c|c|c|c|}
\hline الترتيب & معامل الجودة & الانحراف المعياري & المتوسط & التصميي \\
\hline 3 & 96.83 & 0.79 & 43.57 & المنتج 1 \\
\hline 6 & 90.48 & 2.63 & 40.71 & المنتج r \\
\hline 1 & 100.00 & 0.00 & 45.00 & المنتج r \\
\hline 4 & 96.19 & 1.11 & 43.29 & المنتج ؛ \\
\hline 1 & 100.00 & 0.00 & 45.00 & المنتج ه \\
\hline 2 & 99.05 & 0.79 & 44.57 & المنتج 9 \\
\hline 5 & 94.29 & 1.72 & 42.43 & v المنتج v \\
\hline
\end{tabular}




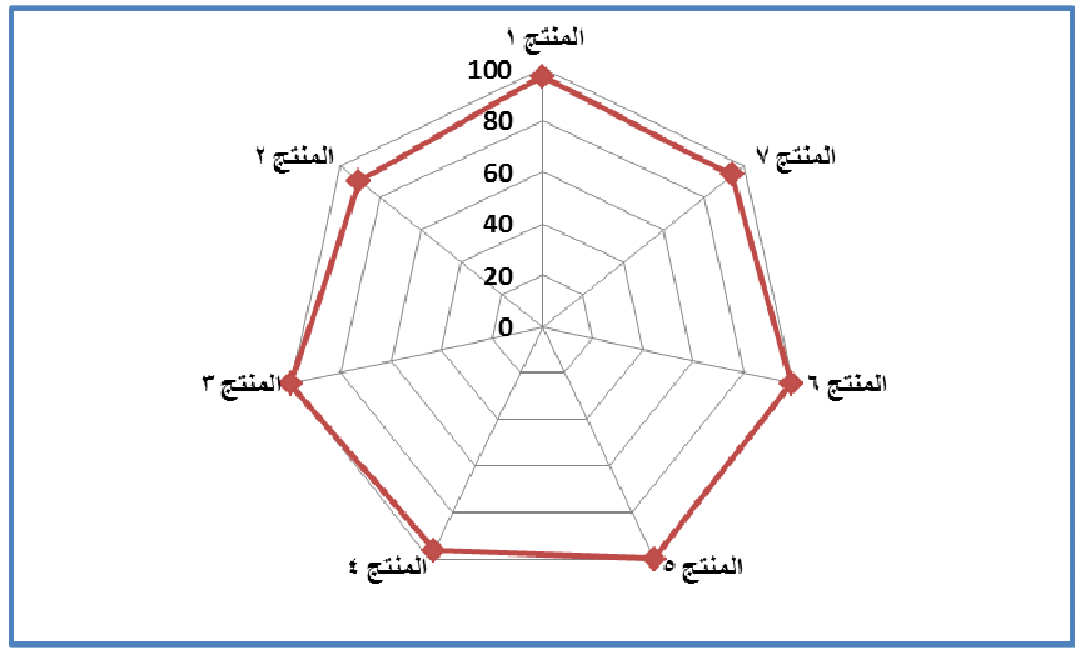

شكل (^) يوضح معامل الجودة لدرجات المنتجات المنفذة وفقا لأراء المستهلكين .

$$
\text { من الجدول (17) والشكل (^) يتضح أن: }
$$

فنجد أن أفضل المنتجات المنفذة ِِّ تحقيق محاور الاستبيان (ككل)، وفقا لأراء المستهلكين اندين

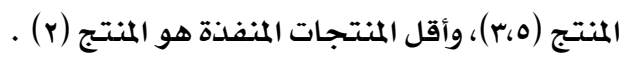

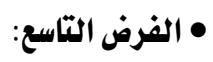

"توجد علاقة ارتباطية بين ترتيب المحكمين والمستهلكين للمنتجات المنفذة ِِ إثراء

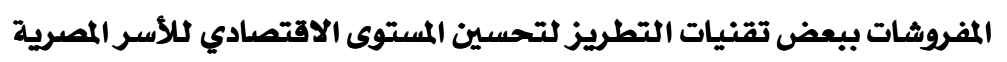

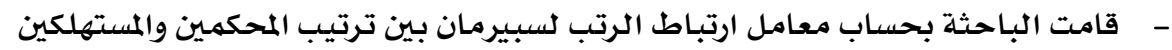

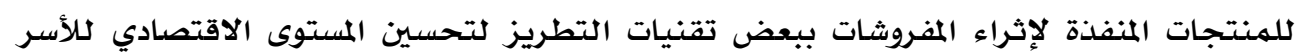

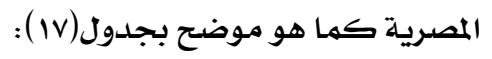




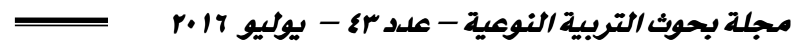

جدول (IV) العلاقة الارتباطية بين ترتيب المحكمين والمستهلكين للمنتجات المنفذة

لإثراء المفروشات ببعض تقنيات التطريز لتحسين المستوى الاقتصادي للأسر المصرية

\begin{tabular}{|c|c|c|c|c|c|c|c|}
\hline & & المستهلكين & & & المحكمين & & \\
\hline معامل الارتباط & الترتيب & معامل الجودة & المتوسط & الترتيب & معامل الجودة & المتوسط & التصميم \\
\hline \multirow{7}{*}{ 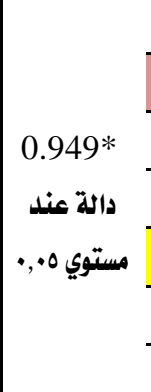 } & 3 & 96.83 & 43.57 & 3 & 98.59 & 26.62 & المنتج 1 \\
\hline & 6 & 90.48 & 40.71 & 7 & 92.42 & 24.95 & المنتج r \\
\hline & 1 & 100.00 & 45.00 & 2 & 99.29 & 26.81 & المنتج r \\
\hline & 4 & 96.19 & 43.29 & 5 & 97.53 & 26.33 & المنتج ؛ \\
\hline & 1 & 100.00 & 45.00 & 1 & 99.82 & 26.95 & المنتج ه \\
\hline & 2 & 99.05 & 44.57 & 4 & 98.24 & 26.52 & المنتج 9 \\
\hline & 5 & 94.29 & 42.43 & 6 & 96.65 & 26.10 & المنتج v \\
\hline
\end{tabular}

تم حساب معامل ارتباط الرتب لسبيرمان لمعرفة العلاقة الارتباطية بين ترتيب المحكمين

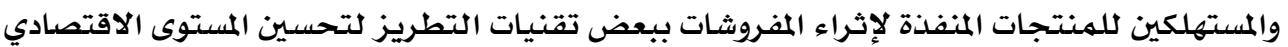

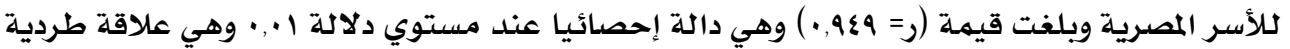

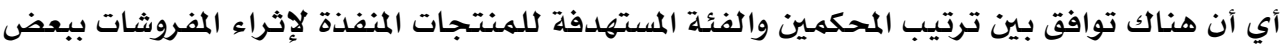

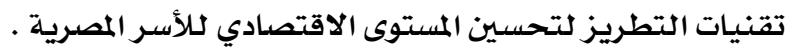
التتوصسات

ا. إنشاء مواقع تعليميلة على شبكة الانترنت تقـوم بعرض الفكرة لتخدم عدد كبير مـن المهـمـين

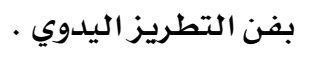

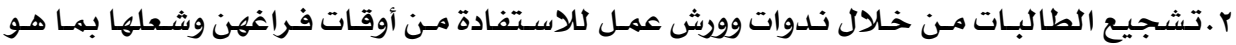

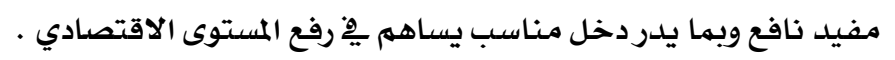

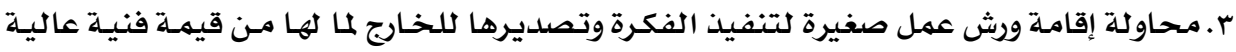

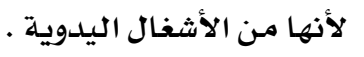

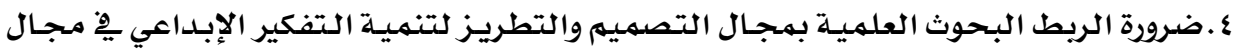

$$
\text { الصناعات الصغيرة . }
$$

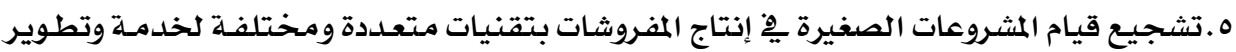

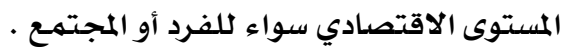

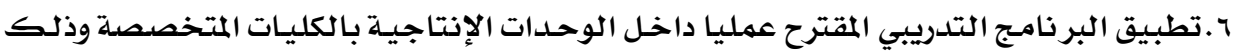

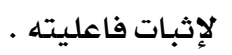

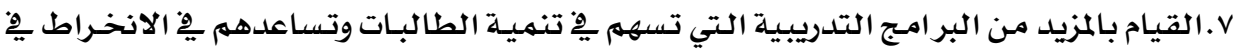




\section{أولا: المراجع العربية}

1 أحمد منصور ،1997:" الأجهزة والأدوات التعليمية " دار الوفاء للطباعة والنشر ، المنصورة ، مصر .

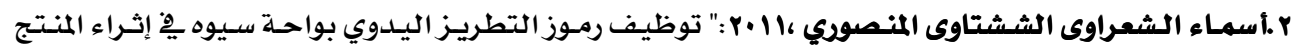

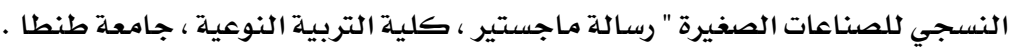

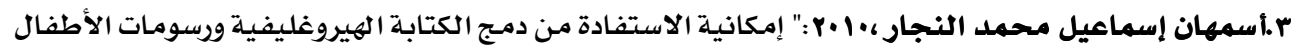

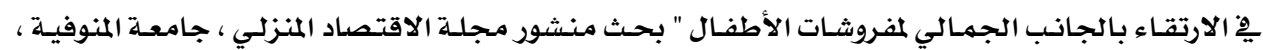

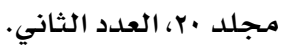

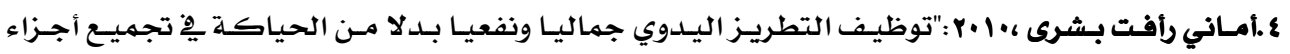

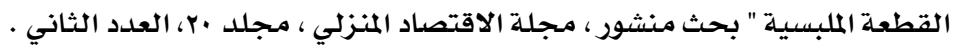

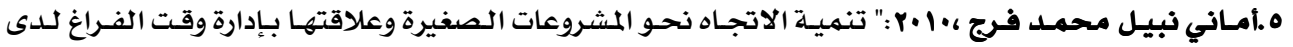

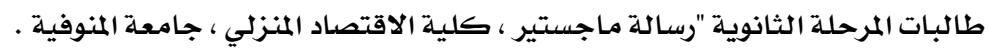

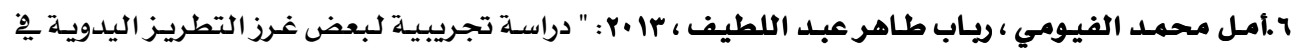

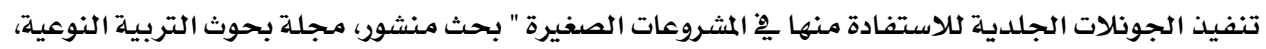
عدد بrا، جا.

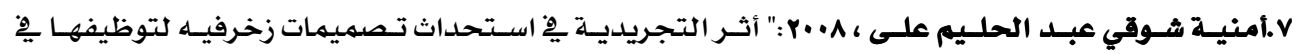

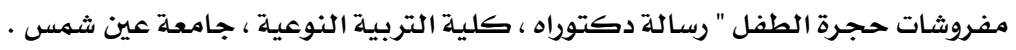

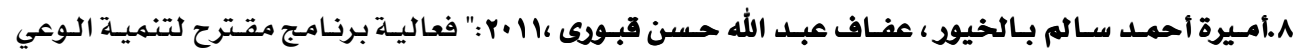

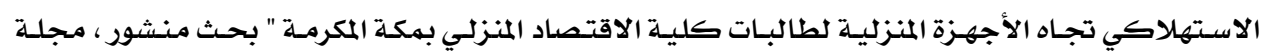

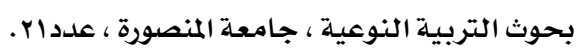

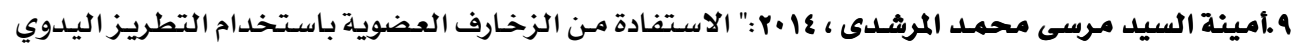

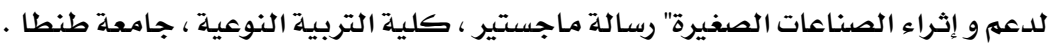

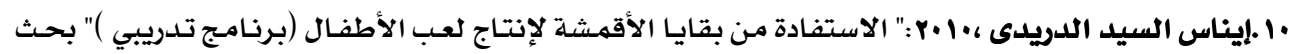

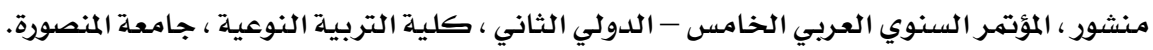

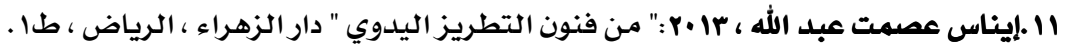

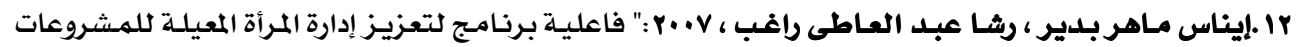

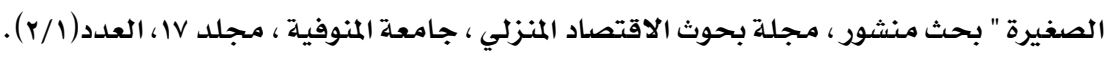

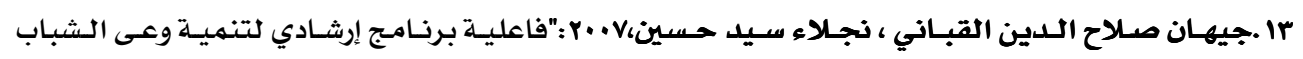

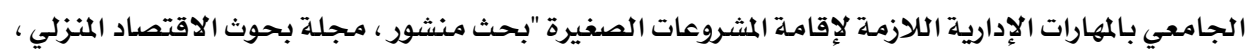

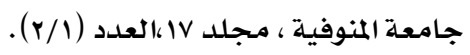

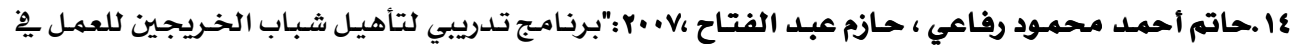

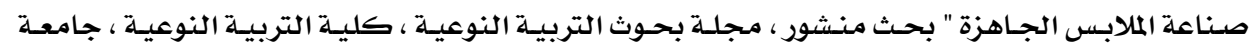


مجلة بحوث التربية النوعية - علدد باء - ميوليو

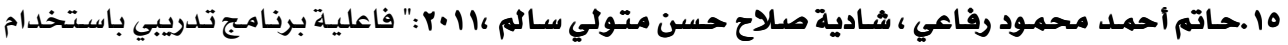
الوسائط المتعددة "المالتى ميديا" لتتميلة مهارات الكوادر الفنية فٍِ مصانع الملابس الجـاهزة " بحث منشور ،

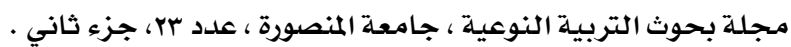

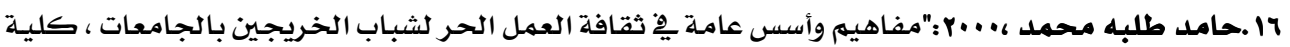

التجارة ، جامعة الزقازيق ، فرع بنها.

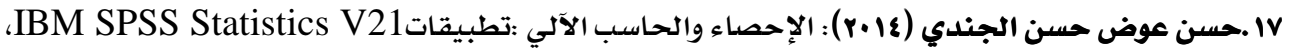
طا، مكتبـة لأنجلو المصريـة،القاهرة. 1 إداليا احمد محمد مهني،|| •ץ:" استخدام الشرائط ِِّ التطريزوالتوصيل الزخرفى لإثراء المفروشات"رسالة ماجستير ، كلية التربية ، جامعة عين شمس . 19 .دعاء عبد المجيد إبراهيم جعفر ،Q . .r:"إمكانية إثراء القيم الجمالية للمفروشات المنزلية باستخدام أسلوب

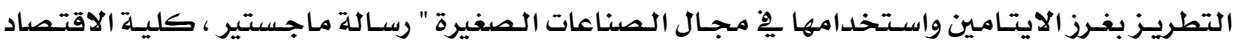
المنزلي ، جامعة المنوفيـة .

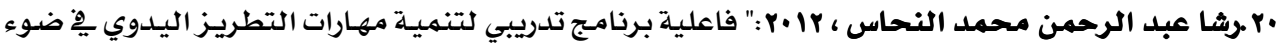
الصناعات الصغيرة ودورها ِِِ التنمية " بحث منشور ، مجلة الاقتصاد المنزلي ، مجلد بr، العلدد الرابع.

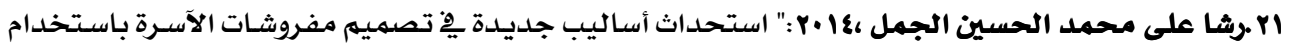
تقنيات التطريز الآلي"رسالة دكتوراه ، كلية الاقتصاد المنزلي ، جامعة المنوفية .

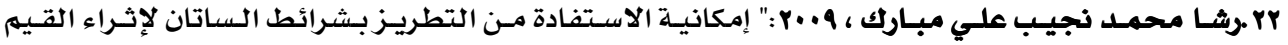
الجماليـة لبعض النهماذج المنفـذة لملابس المحجبـات و مكملاتـه" ، رسـالة دكتوراه ، كليـة التربيـة النوعيـة ، جامعة المنوفيـة .

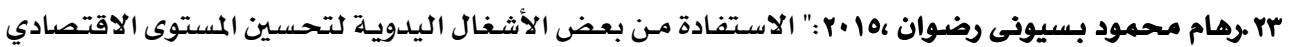
لكلأسرة المصرية " رسالة ماجستير ، كلية التربية النوعية ، جامعة المنصورة .

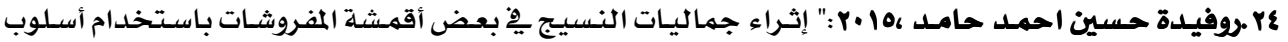
الصباغة والطباعة والإفادة منها ِِِ مجـال الصناعات الصغيرة" رسـالة ماجستير ،كليـة التربيـة النوعيـة ، جامعة جنوب الوادي .

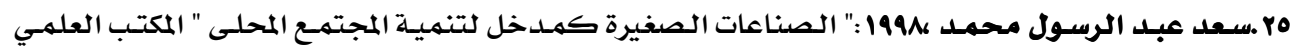
للنشر والتوزيـع.

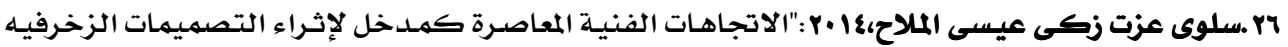
للمفروشات المنزلية " رسالة دكتوراه، كلية التربية النوعية ، جامعة المنصورة .

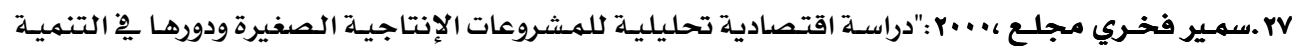
الاقتصادية والاجتماعيـة" بحث منشور ، مجلة الإسكندريـة للبـحوث الزراعية ، العدد العاشـر .

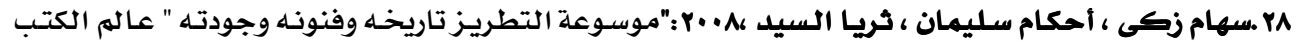




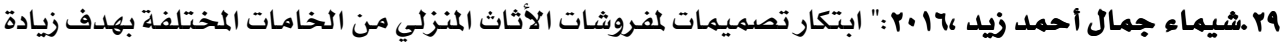
القيمة الجمالية لها" رسالة ماجستير ، كلية الاقتصاد المنزلي ، جامعة المنوفيـة .

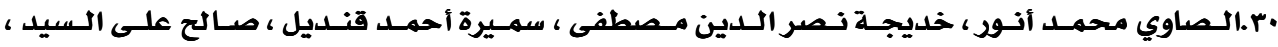

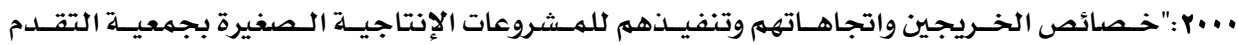

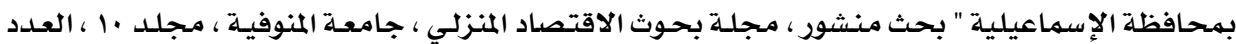
$. Y / I$

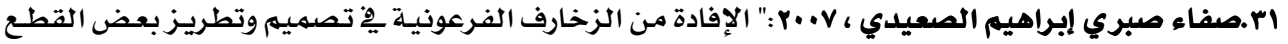
الملبسيه لدعم السياحة ِِّ مصر " رسالة دكتوراه ، كلية التربية النوعية ، جامعة المنصورة .

ץ..عبد المنعم صبري ، رضا صالح 19VO:" معجم المصطلحات النسيجية " جمهورية ألمانيا الديمقراطية .

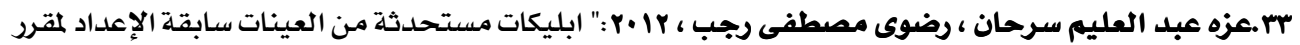
التصميهم والتطريز لإثراء مفروشـات حجرة الطفل " بحث منشور ، المؤتتـر السنوي العربي السـابع - الدولي الرابع ، كلية التربية النوعية ، جامعة المنصورة .

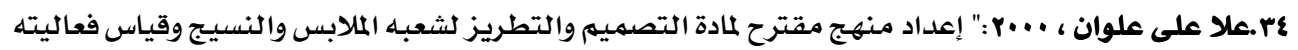
" رسالة دكتوراه غير منشورة ، كلية الاقتصاد المنزلي ، جامعة حلوان .

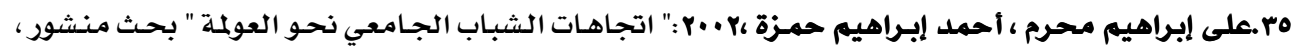
مجلة دراسـات ِِ الخدمـة الاجتمـاعية والعلوم الإنسانية "كلية الخدمة الاجتماعية ، جامعة حلوان ، العدد

$$
\begin{aligned}
& \text { الثاني عشر. } \\
& \text { 7r.على السلمي 199V، :"التخطيط والمتابعة " دار الغريب للنشر والتوزيع ، القاهرة. } \\
& \text { IVV }
\end{aligned}
$$

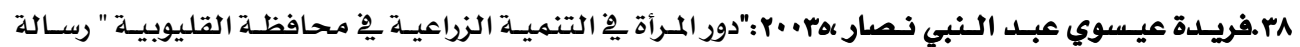
ماجستير غير منشورة ، كلية الزراعة ، جامعة عين شمس .

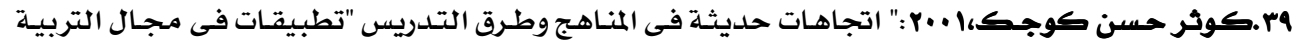

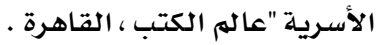
• ع .لياء إبراهيه أحمد عبد الفتاح ، • • r :"برنامج تدريبي لتأهيل الخريجات لصناعة بعض مكملات الملابس من بقايا الأقمشة " بحث منشور ، المؤتمر السنوي العربـي الخـامس - الدولي الثاني ، كليـة التربيـة النوعيـة ، جامعة المنصورة.

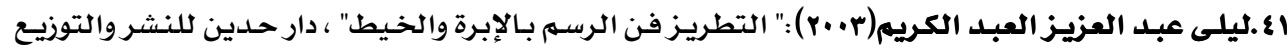
الكويت. rع .محمود رزق إبراهيم عياد ، 1 +r:" دور الصناعات الصغيرة والمتوسطة يْ تشغيل شباب الخريجين يِّة محافظة الدقهلية" رسالة دكتوراه ، كلية الزراعة ،قسهم الإرشاد الزراعي والمجتمـع الريفي ،جامعة المنصورة .

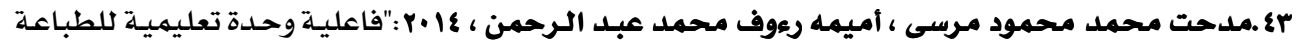
بالشاشة الحريريـة ضمن مقرر تصميهم وطباعة المنسوجات لتنميـة معـارف ومهارات طالبـات قسم الاقتصـاد 
مجلة بحوث التربية النوعية - علدد باء - يوليو

المنزلي بكليـة التربيـة النوعية " بحث منشثور ، مجلـة الإسـكندرية للبحـوث الزراعيـة ، كليـة الزراعـة ، جامعـة

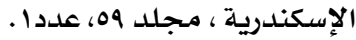

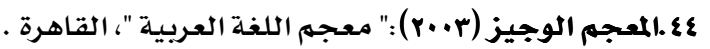

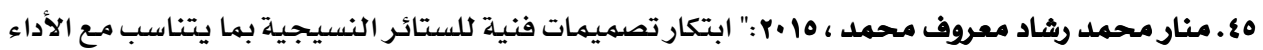

الجمالي والوظيفي لخدمـة الصناعات الصغيرة" رسالة دكتوراه ، كلية الاقتصاد المنزلي ،جامعة المنوفية .

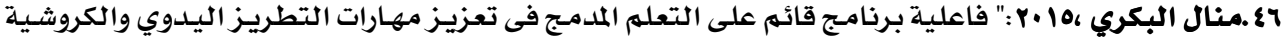

لطلاب الاقتصاد المنزلي " بحث منشور ، مجلة التصميهم الدولية ، مجلد ه، عدد ب.

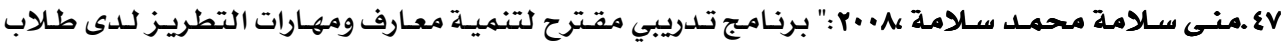

الجامعة غير المتخصصسين "رسالة ماجستير ، كلية الاقتصاد المنزلي ، جامعة حلوان .

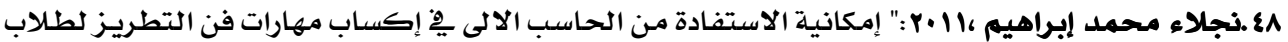

المرحلة المهنية " رسالة ماجستير ، كلية الاقتصساد المنزلي ، جامعة المنوفية .

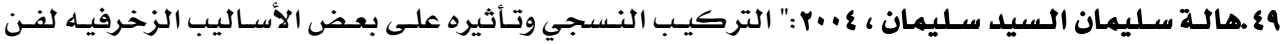

التطريز (دراسة فنية تطبيقية مقارنة )" رسالة ماجستير ، كلية الاقتصاد المنزلي ، جامعة حلوان .

•ه .هدى خضري عبداركيم محمود ، أميمهه رعوف محمد عبد الرحمن ، 10 · :" فاعلية برنامج تدريبي لتنمية

المعارف والمهارات لغـرزه (البرومستيك) "Broomstick" لطالبـات قسهم الاقتصـاد المنزئي " بحثث منشور ،

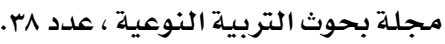

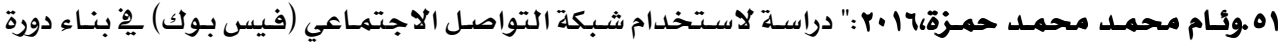

تدريبية لتعليه فن التطريز بالشرائط " بحث منشور ، مجلة التصميهم الدولية ، عدد . .

ror or

الصناعات الصغيرة " بحث منشور ، مجلة البحوث الزراعية ، كلية الزراعة ، جامعة الإسكندرية ، مجلـد •ج،

عدد r.

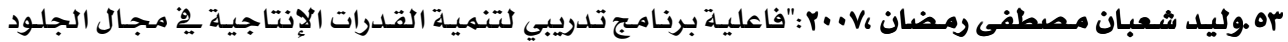

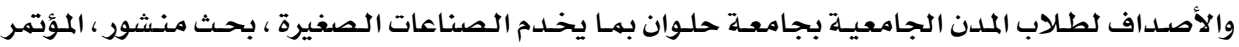

السنوي الثاني ، كلية التربية النوعية ، جامعة المنصورة .

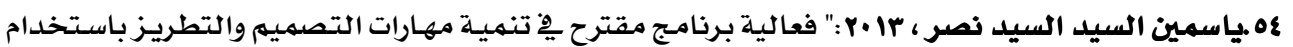
الفيديو التفاعلي للطالبـات المعلمـات بكليـة الاقتصاد المنزلي " رسـالة مـاجستير ، كليـة الاقتصـاد المنزلي ،

جامعة حلوان .

\section{ثانيا: المراجع الأجنبية ومواقع الانترنت}

55.Carolyn Ambuter,1972:'Comlete book of needle point with the most comprehensive, Thomas Crowell Company ,New York.

56.Dan William,1994:'Evaluation the Economic Feasibility of Small Business Us, American Demographic. 


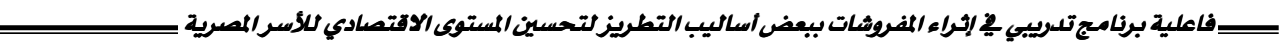

57.Donald W,1991:'Marketing Strategies of Small Industrial Marketing Management, Vol20.

58.Dorothy Wood.1999:"The practical encyclopedia of Sewing ,Lorenz book.

59.Gillo,Johns\& Sentence .bruan,1999:"Auisual Guide to traditional techniques ,thame and Hudson ,ltd, London.

60.Gladden Kathleen.2001:'Hanging By A thread Industrial restructuring and Social Reproduction in A Colombian City, PHD ,University of Florida.

61.Press,Ebury,1981:’Needle Point ,Darling Kindersley limited , London.

62.Ross Lawrence peckford,2000:'Leadership Training in Human Resources Development" Canda.

63. www.wikipedia.com. 


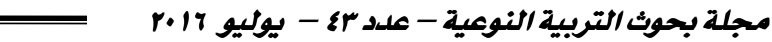

\title{
The Efficiency Of A Training Program In Enriching Furnishings Using Some Embroidery Techniques In Order To Improve The Economic Level of The Egyptian Families
}

\author{
Dr. / Rasha Abbas Mohamed Metwally Elgohary"
}

\section{summary:}

In recent years, we have witnessed an increased interest in the field of Small Enterprises, thus, they are considered now as the backbone of the production process on both the local and international levels. Today, Small Enterprises are seen as paths of salvation, used to survive any economic crises, due to their high capabilities of developing the economy, modernizing the industry, facing the escalating unemployment problem, preparing a labor base, activating the role of youth, creating a spirit of integration and competition between the different projects, and developing the living standard of individuals.

Nowadays, Embroidery has come to be a very important element in ornamenting the different fabrics, whether it was manual or mechanical, due to what it adds of tenderness and beauty to the artistic pieces. Thus, the art of Hand Embroidery has become an important factor in supporting the economy of many countries that consider it as a major source of national income by exporting the embroidered products outside the country. Hence, the art of Embroidery has been used widely in ornamenting many clothes and several artistic pieces used as accessories to the clothes; and it has also been used in ornamenting headdresses and furnishings, increasing the product's beauty and artistic value.

In this regard, the role of Embroidery, as a technique of ornamenting the fabrics of different furnishings, is shown through many methods and different materials, such as threads with their different types including "the fabric, the color and the textile measurement". Therefore, Embroidery could be considered as one of the most appropriate methods for the artistic expression.

On the foregoing, the development of curricula is considered to be a vital issue for everyone involved in the process of education. In addition, the training programs are considered as one of the most common forms of developing the curricula; thus, they are a previously planned scheme in a comprehensive form, including the educational material, the associated

*Assistant Professor of Textile and Clothes Department of Home Economics - Faculty of Specific Education - Mansoura University 
educational activities and aids, the teaching methods, and the continuous processes of assessment; which as a whole result in reaching the desired goals. This process needs having certain experiences, so that the learner could acquire specific information and skills. Moreover, experimentation in the field of Embroidery is considered as one of the most important necessities in order to achieve the objectives of this field.

In this sense, a training program had to be designed for the female students of the Third Year in the Faculty of Home Economics, with the purpose of training those students on producing furnishings with high value suitable to be the core of a Small Enterprise. Hence, the researcher had to determine the efficiency of this training program in providing the female students with the necessary knowledge qualifying them to execute furnishings suitable for the field of small industries. In addition, the researcher had also to determine the contribution of this training program in providing the female students with the necessary skills, qualifying them to execute furnishings suitable for the field of small industries. Thus, this training program shall contribute to solving the problem of unemployment and improving the economic level of both the individual and the family.

In this regard, through the implementation of the proposed training program, the relevant tests and questionnaires and the statistical processing, the researcher found out that there are significant differences at the significance level of $(\leq 0.05)$ between the average scores of the female students in both the pre and post implementations for the Knowledge Acquisition Test, in favor the post implementation. In addition, there is a statistically significant difference at the significance level of $(\leq 0.05)$ between the average scores of the female students on the Skillful Performance Evaluation Scale, with the mastery level of (80\%) in favor of the female students' scores. Furthermore, there are statistically significant differences between the executed products in achieving the following in the executed products: (the suitability of the Smocking technique, the suitability of Stripes Embroidery and the furnishings quality), according to the opinions of the arbitrators. Moreover, there are statistically significant differences between the evaluation axes of the executed products, according to the opinions of the arbitrators; not to mention that there are statistically significant differences between the executed products, according to the opinions of the consumers. Finally, there is a correlation between the order of the arbitrators and that of the consumers for the executed products, with regard to enriching the furnishings through some Embroidery techniques in order to improve the economic level of the Egyptian families. 